QL 77

P5 $\mathrm{A3}$

PRICE, FIFTEEN CENTS.

1905

Copy 1

\title{
GUIDE TO THE GARDEN
}

OH THE

ZoOLOGICAL SOCIETY

OF PHILADELPHIA

(F.IIRMONT P.IRK).

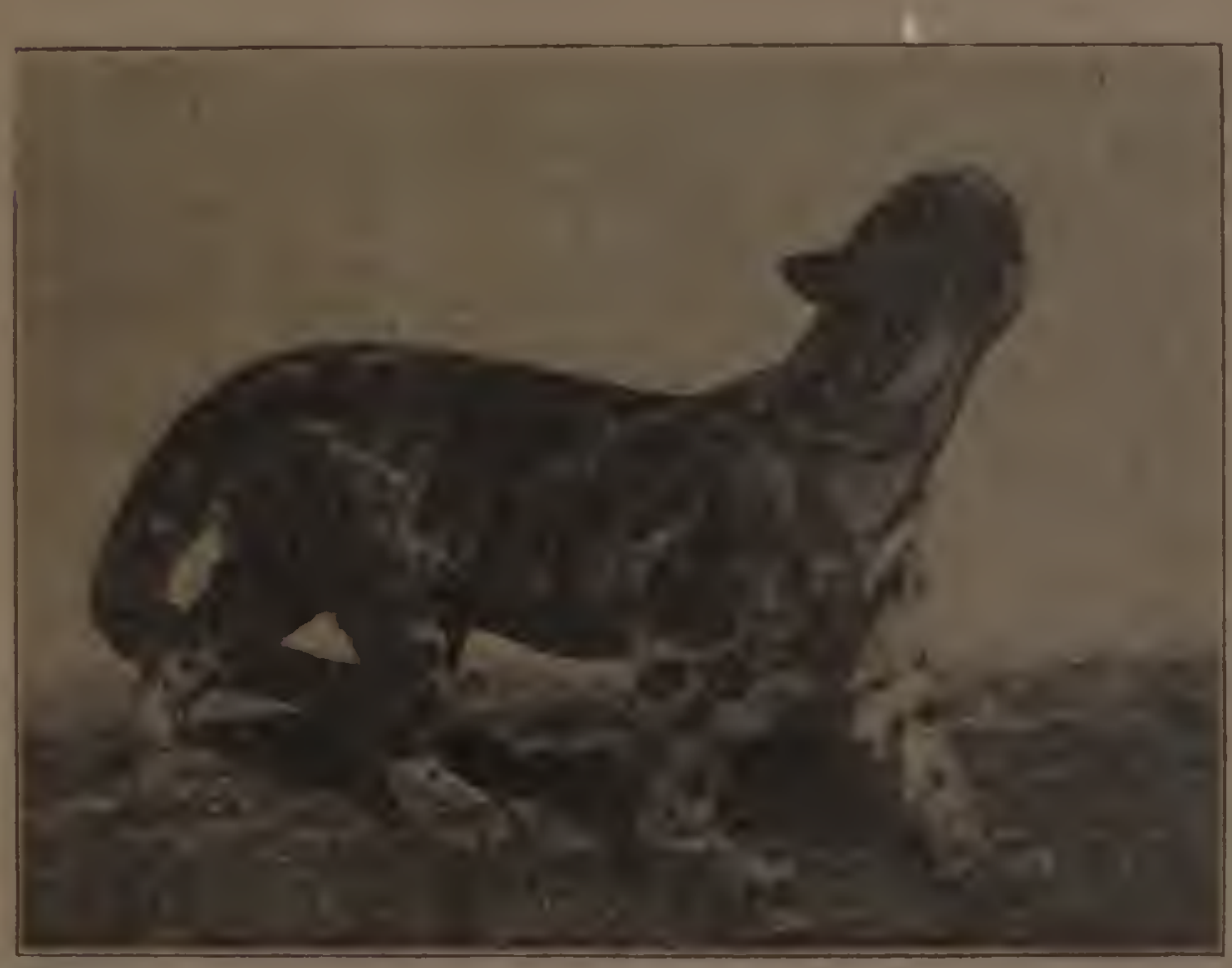

NINTH EDITION.

REVISED AND CORIRIC'TH D

1905.

BY ARTHUR ERIIIN BROWN,

Nemter of the Academy of Natural Sciences of Philadelphia, the American Philorophical Society, \&c.,

SECRETARY OF THI; SOLIETY. 


\section{THE ZOOLOGICAL SOCIETY}

OF PHILADELPHIA

IVas incorporated in 1859 . The Garden was first opened to the public July ist, I 874 .

It has the following classes of members, who are elected by the Board:-

r. AnNUal. - These pay five dollars a year and receive one annual ticket of admission.

2. JUnion.-These are minors whose membership expires when they reach the age of eighteen years. They make one payment of $\$ 5$ when elected.

3. Life Members. - These pay fifty dollars upon election, in lieu of all future dues. Annual members may at any time become Life Members upon the payment of forty-five dollars additional.

4. Honorary Members are those who, in consequence of liberality to the Society, or who, holding a distinguished position in science, are elected by the Board.

5. Corresponding Members are those who are interested in the Society, living out of the city, and are of service to it abroad.

Nembers are admitted to the Garden during the time it is open to the public, which is from 9 A. M. until sunset, every day in the week, including Sunday.

Persons who wish to become members will please communicate with the Secretary of the Society. 


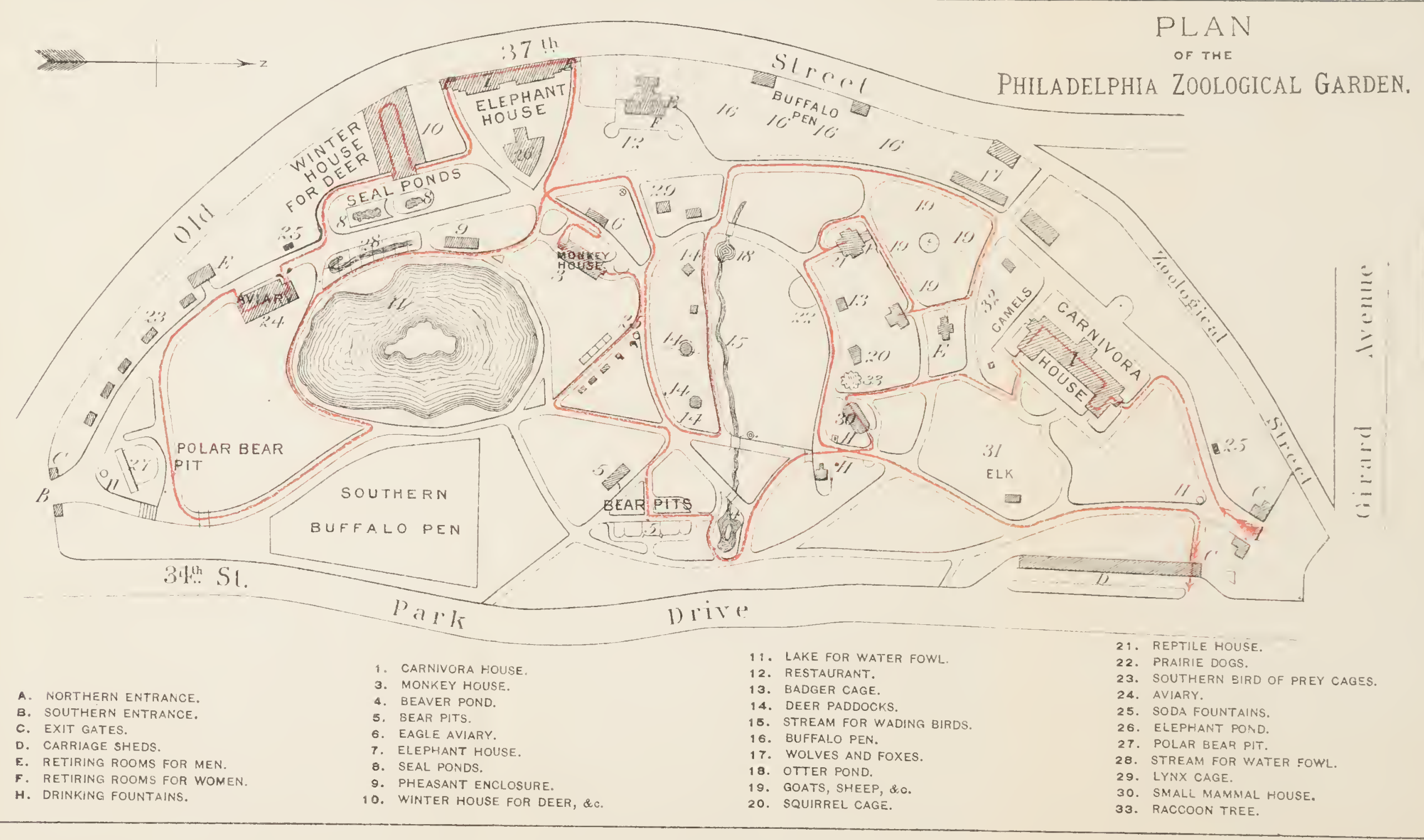




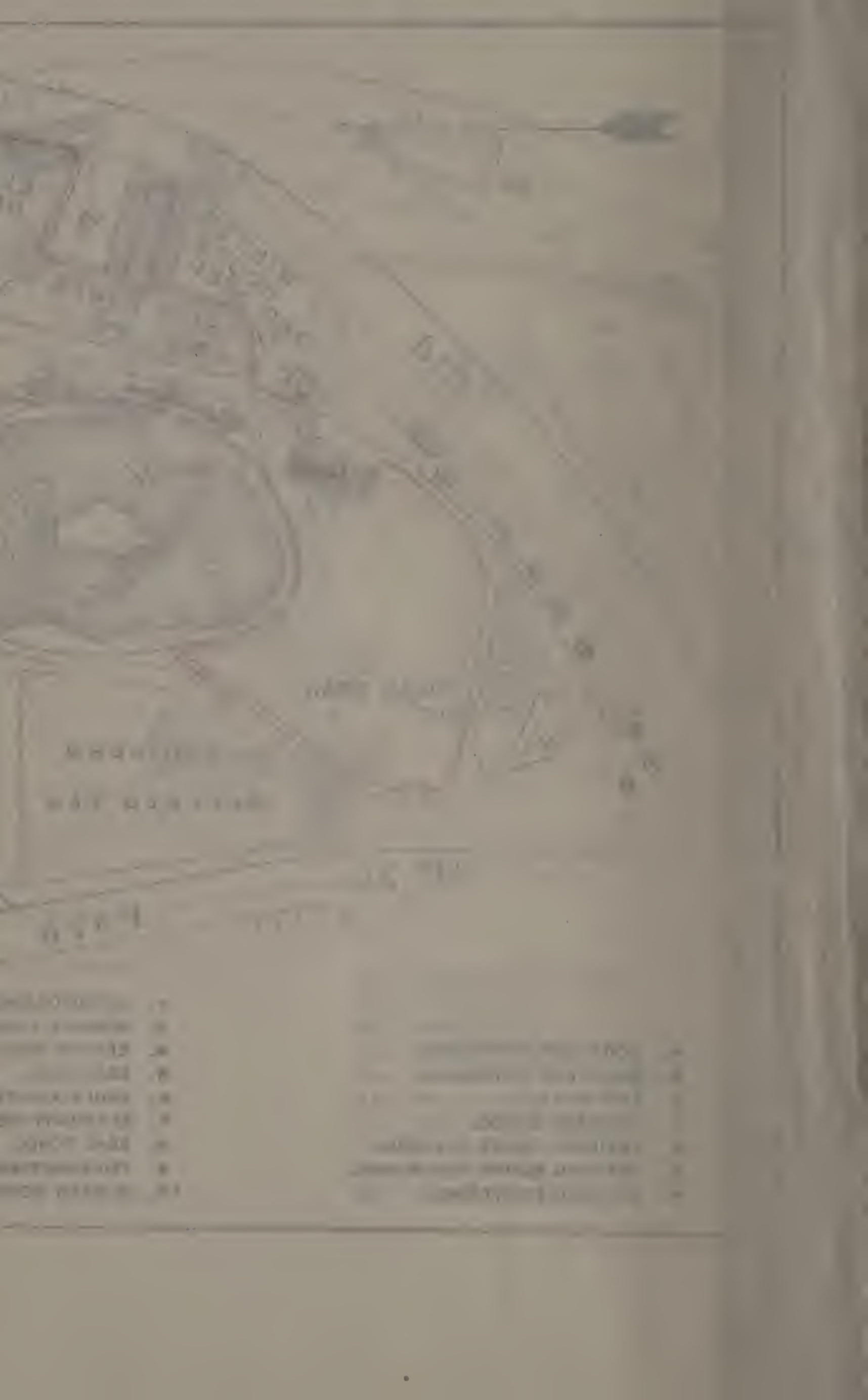




\section{GUIDE TO THE GARDEN}

OF THE

\section{ZOOLOGICAL SOCIETY}

OF PHILADELPHIA

(FAIRMOUNT PARK).

NINTH EDITION.

REVISED AND CORRECTED.

BY ARTHUR ERWIN BROWN,

Member of the Academy of Natural Sciences of Philadelphia, the American Philosophical Society, \&c., SECRETARY OF THE SOCIETY. 


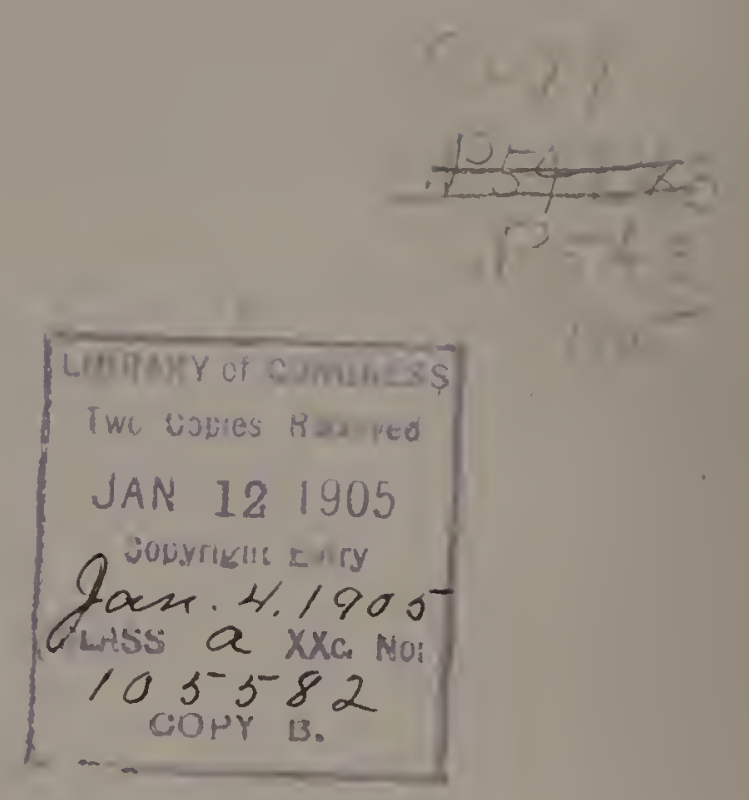

Entered, according to Act of Congress, in the year 1905, by ALLEN, LANE \& SCOTT, In the Office of the Librarian of Congress, at Washington, D.C. 


\section{INTRODUCTION.}

To a large class of visitors, who desire to find in a zoological collection instruction as well as anusement, a brief statement of the meaning and the relative value of the groups into which the animal kingdom is divided by naturalists, will not be without interest. To arrive at a correct understanding of these, it is necessary to look at the animal world, not as a mere mass of living forms bearing haphazard resemblances to each other, but as composed of great family groups of beings, formed, more or less, on the same plan, varying, it is true, to a vast extent in its mode of expression, but all the forms of which, starting from a common point, may be arranged in more or less divergent series, presenting combinations of structural peculiarities, differing from each other to an extent somewhat proportionate to their distance from the starting, point.

The first complete systematic classification of living forms was made by the Swedish naturalist, Linnæus, about the middle of the eighteenth century, chiefly from external resemblances; but the growth of the great conception of organic evolution within the past forty years has profoundly changed both the methods and the views of zoologists, and the systems now in use, based mainly upon anatomical characters, aim at indicating the real relationship and successions in time, borne to each other by species now existing and those already extinct. 
Under a system which, though simple, is sufficiently comprehensive for the present purpose, the primary divisions are :-

I. Vertebrata. -Mammals, birds, reptiles, batrachians, and fishes.

II. Tunicata.-Ascidians, sea squirts (primitive vertebrates).

III. Mollusca.-Oysters, cuttles, snails, slugs, \&c.

IV. Arthropoda.—Labsters, crabs, spiders, insects, \&c.

V. Echinodermata.-Starfish, crinoids, sea urchins, \&c.

VI. Vermes. -Worms.

VII. Coelenterata.-Hydras, polyps, corals, sea anemones, jellyfish, \&c.

VIII. Spongie. - Sponges.

IX. Protozoa.-Amøeba, infusoria, rhizopods, \&c.; the lowest forms of animal life, many of them microscopic, and bordering closely on the vegetable world.

At the present time about 386,000 species of living animals are known to systematic zoology. Of these 2500 are mammals, 12,500 are birds, 4500 reptiles and batrachians, and 12,000 fishes.

It is with these only that the collection in the Garden has to deal. The Vertebrates-animals possessing a skeleton of bone or cartilage, enclosing cavities in which the soft parts of their organization are contained and protected from injuryare arranged in classes, according to the nearness with which they approach to one of the five great types of structure which have been found to exist among them:-

I. Mammalia.-Animals which suckle their young.

II. Aves, or birds.

III. Reptilia.-As turtles, lizards, and serpents.

IV. Batrachia.-As frogs, toads, and salamanders.

V. Pisces, or fishes. 
These classes are broken up into orders, each possessing an association of structural characters which is common to all the individuals included in it, and in which they differ from all others in their class. These orders have been differently constituted and arranged, according as different points have been made use of for their determination.

They are again divided into smaller groups called families, which, possessing the characteristic structure of their order, yet depart in some minor consideration from its type-or, in other words, from that form which has been taken to show most clearly the peculiarity of the order.

Families are again broken up into genera, which bear to them much the same relation as that which they, in turn, bear to orders. Thus - to illustrate with a familiar examplethe lion, tiger, leopard, \&c., are all cats and belong to one genus-Felis; they are classified as follows:-

Division Vertebrata-because they have a backbone or vertebral column.

Class Mammalia-because they have organs peculiar to those vertebrates which suckle their young.

Order Carnivora-because their plan of structure is that possessed by mammals which live on flesh.

Family Felida-because, in addition to the above, they possess in common certain details of teeth, claws, and other structural points, which none of the other carnivora share.

Genus Felis-because certain minor modifications are unlike those existing in a few other individuals, which so far have agreed with them, but which now become another genus of the same family.

But to go a step farther-the lion, tiger, and leopard, though so far they have been precisely similar, are yet recognizable-there are still smaller points of difference; they 
are, therefore, said to be different species, and a second name is added to the scientific designation of their genus; thus the Lion is Felis leo, the Tiger is Felis tigris, and the Leopard is Felis pardus.

Of late years a practice of employing a third, or subspecific name, to designate grades of unlikeness more minute than those of specific value, has come into use. These names are written in Latinized form, because Latin is a language in use by men of science of all nations, and uniformity of practice is thereby reached.

In the following scheme it is not intended to enter upon the close details of classification, the object being merely to place broadly before the visitor an idea of the relationship, within the limits of class and order, of the animals which he sees in the Garden :-

\section{Class I. Mammalia :-}

r. Primates.-Man, apes, monkeys, marmosets.

2. Lemures.-Lemurs, galagos, loris ("half apes.")

3. Carnivora.-Cats, civets, paradoxures, ichneumons, hyenas, dogs, wolves, foxes, weasel, badger, skunk, otter, raccoon, bears.

4. Pinnipedia.-Seals, "sea lions," walrus.

5. Insectivora.-Moles, shrews, hedgehog, galeopithecus.

6. Chiroptera.-Bats, "flying foxes."

7. Rodentia.-Squirrels, spermophiles, marmots, "prairie dog," beaver, rats, mice, voles, capromys, porcupines, cavy, agoutis, hares, rabbit.

8. Hyraces.-Hyrax, "coney."

9. Proboscidea.-Elephant.

I0. Ungulata.-Rhinoceros, tapir, horse, ass, oxen, antelopes, sheep, goats, giraffe, deer, camel, llamas, hippopotamus, swine.

II. Cetacea.-Whales, porpoises, dolphin, \&c.

12. Sirenia.-Manatee, "sea cow," dugong. 
13. Edentata.-Sloths, armadillos, ant eaters.

14. Effodientia.-Pangolin, aard-vark.

15. Marsupialia.-Kangaroos, phalangers, petaurus, wombats, dasyures, opossum, \&c.

16. Monotremata.-Ornithorhynchus, echidna.

\section{Class II. Aves:-}

I. Passeres. - An immense assemblage containing the majority of birds: thrushes, warblers, wrens, vireos, wagtails, swallows, bulbuls, orioles, shrikes, sugarbirds, tanagers, finches, sparrows, weavers, troupials, starlings, mynahs, paradise birds, crows, jays, larks, \&c.

2. Picarice.-Woodpeckers, hummingbirds, whip-poor-will, kingfishers, hornbills, motmots, toucans, cuckoos, touracous, trogons, \&c.

3. Psittaci.-Macaws, cockatoos, parrots, parrakeets, lories.

4. Striges. -Owls.

5. Accipitres.-Eagles, hawks, buzzards, falcons, vultures.

6. Columba.-Pigeons, doves.

7. Pterocletes. - Sand grouse.

8. Gallina.-Grouse, pheasants, partridges, quail, peafowl, guinea, turkey, fowl, curassows, guans.

9. Hemipodii.-Bush quail.

Io. Fulicarice.-Rails, coots, water hens.

I I. Alectorides.-Cranes, trumpeters, bustards.

I2. Limicola.- "Shore birds," curlews, plover, woodcock, snipe, \&c.

I3. Herodiones.-Herons, bitterns, egrets, storks, ibises.

14. Palamedea.-Screamers.

15. Odontoglossa.-Flamingoes.

I6. Anseres.-Swans, geese, ducks.

I7. Steganopodes.-Pelicans, gannets, cormorants, "water turkey."

I8. Gavia.-Gulls, terns.

19. Tubinares.-Petrels, albatross.

20. Pygopodes.-Divers, loons, grebes, auks.

2I. Impennes.-Penguins.

22. Crypturi.-Tinamous.

23. Struthiones.-Ostrich, cassowaries, emu, rhea, apteryx. 
CLAES III. Rertiliz:-

I. Crocositsa-Alligators, crocodiles, caiman, de.

2. Che?omi-Turtles, termpins, tortoises.

3. Rig;nolohnalia-Tuatera "lizard."

2. Lic:ytitia-Lizards, geckos, chameleons, itc.

5. Ofhrian-Snakes.

\section{CLASS IV. Butruchia:-}

I. Ecuatuata.-Frogs, toads, tree toads.

2. Couduta-Salamanders, newts, siren, proteus, Sc.

3. -Apozic-Cacilians, "burrowers, without legs." 


\title{
GUIDE TO THE GARDEN
}

\author{
w.m.
}

\section{LOGICAL \\ SOCIETY}

OF PHILADELPHIA.

THE visitor taking the route laid down on the accompanying plan of the Garden, is supposed to enter at the Girard avenue gate; those entering at the other end of the Garden can, however, pursue the same course by taking the path to the right around the lake (No. I I), and following the route until they come to the Penn Mansion, when they should turn to the left and enter the Carnivora House, after which the route can be followed until they are brought back to the point from which they started. As many of the animals are shifted from one place to another at different seasons, they will not always be found at the location designated by the Guide; each cage, however, bears the name of the animal which it contains, and its description can readily be found by a reference to the index at the close of the book.

It should be added that a collection of living animals is constantly changing by deaths and by additions. At no moment, therefore, can it exactly correspond to a printed catalogue, which will always contain a few species not seen by the visitor in the enclosures, and on the other hand will be silent concerning others among late arrivals.

\section{No. I.-THE CARNIVORA HOUSE.}

THERE would appear to be little in common between the domestic tabby, which lies purring before the fire, and the majestic lion, which the visitor sees with much pleasure is here separated from him by a solid framework of iron, yet there is no difference between them so far as the essential 
points of their structure are concerned, and none even in their habits, excepting such as are caused by the different circumstances under which they live. The one preys on antelope, while the other lives on rats and mice; but they hunt for them and catch them in one and the same manner. They are the two extremes of the Felida, or cat family, regarded in point of size.

The domesticated house cat probably originated in Egypt not less than thirty to thirty-five centuries ago, and most likely is descended from Felis caligata, a wild species still found in that country.

The true cats-composing the genus Felis-are externally distinguished from the other members of the family, or the lynxes, by their slender form and by a much longer tail than is ever possessed by any of the latter genus.

About fifty species of cats are now known, found in all regions except in the West Indies, Australia, and Madagascar.

The Lion (Felis leo) ranges all through Africa, from the Cape of Good Hope to the Mediterranean, and through a great part of southern Asia, but there, at least, in rapidly lessening numbers.

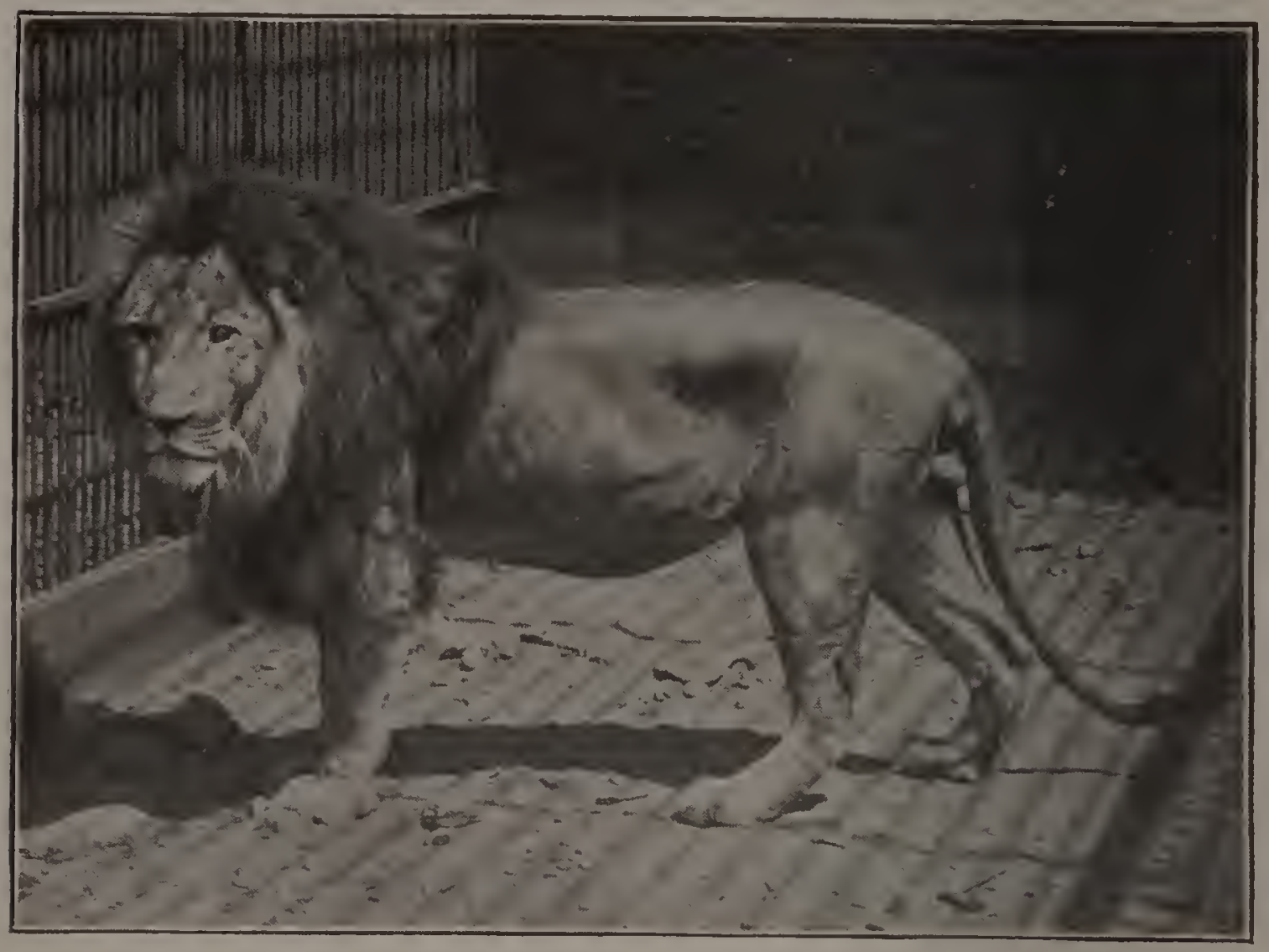

THE AFRICAN LION. 
In ancient times they were known in Greece, but civilization has long since driven them out of Europe.

As with all animals whose wide range of distribution exposes them to many different climates and kinds of food, under the action of which, with other conditions, they are apt to vary more or less, the lion of different parts differs much in appearance, chiefly in color and thickness of mane, but as these variations are indefinite and do not involve the slightest change of structure, they are looked on as being of no specific importance.

The lion reaches maturity at about eight years of age. A full grown male should be from ten to ten and a half feet long, including the tail, and should weigh about four hundred pounds. Mr. F. C. Selous, the famous hunter and explorer of South Africa, states that wild lions rarely grow as large and luxuriant manes as those kept in menageries.

The Tiger (Felis tigris), among the cats, is the sole rival of the lion, in strength and size. Its range is much more restricted, as it is never found outside of Asia, where its principal home is in Hindostan and the adjacent islands, though it is sparingly found in Siberia on the north, and through China into Korea on the north-east. Tigers from the cold regions of northern Asia have fur almost as long and thick as that of the well-known Persian cats.

The male and female tiger are similar in appearance, and have been beautifully adapted by nature for the purpose of stealing unobserved upon their prey; the tawny yellow of their skin, striped with vertical bars of black, blending so perfectly with the jungle of canes and bamboos, among which they live, that it is almost impossible to detect their presence until revealed by motion, when it is usually too late for the startled victim to escape.

Eleven feet in extreme length, with a weight of four hundred and fifty pounds, would be the dimensions of a very large tiger.

The Leopard (Felis pardus) has much the same distribution as the lion, and varies almost to the same extent. The Black Leopard is a rare and beautiful animal, but is merely a color variety of the common form; animals of both colors being found, as is stated, in the same litter.

Among the members of the cat family now found in a wild 
state, the only one which seems to be susceptible of domestication is the CheEtar (Felis jubata), often known as the HUNTING LEOPARD, which is found in India, south-western Asia, and Africa. It differs much in disposition from all of its kind, and so far surpasses them in intelligence and tractability, that for many centuries it has been trained in the East for the purpose of the chase, the animal being blindfolded and led by a chain until a deer or antelope is started, when it is unhooded and loosed to run down the quarry.

The claws of the cheetah being much less retractile than those of other cats, and the skull presenting some marked differences, it is usually placed in a separate genus-Cyncelurus.

The JAGUAR (Felis onça) is the largest of the cats of the New World, Baron Humboldt having described one which equaled the average tiger in size ; it inhabits the hottest parts of the continent from South America into upper Mexico, sometimes even ranging into southern Texas-the principal home of the species being in the dense forests which stretch away from both banks of the Amazon. In appearance it is very similar to the leopard-the jaguar having a shorter tail and the spots covering the skin presenting a more broken appearance.

Many instances are given by South American travelers of the strength and ferocity of the jaguar ; D'Azara, in particular, relates that he once saw one drag off the body of a horse to a considerable distance, and then swim with it across a wide and deep river.

The black jaguar is much more rarely met with than the black leopard, and in menageries is considered a valuable prize.

The American Panther (Felis concolor) covers a greater extent of country in its range than any other existing cat, being distributed through North and South America from Canada nearly to Cape Horn, though in the most settled portions of the former, civilization has generally driven it to the secluded parts of the mountains of the north and east, and the cane brakes of the south.

They are notably wild and shy, and in regions where they are known to abound the animal itself is rarely seen.

They are found of several shades, from silvery gray to reddish 
brown, and are all of one species, though known by the different names of Panther, Puma, Couguar, and Mountain Lion. The latter name was given to them by the early colonists of the country, probably for the reason that the panther, having no mane and approaching in color to the lion, was taken to be a female of that species, which is also devoid of a mane. They are prodigiously active, even among this family of fourfooted athletes, and can cover as much as thirty feet at a bound.

The Clouded Leopard (Felis nebulosa) is perhaps the most beautiful in markings of all the large cats, though it is sufficiently rare in collections to be little known. It ranges from eastern India and Siam, through the Indo-Malayan islands as far as Borneo. At the present time the Society is fortunate in owning a puir of these animals.

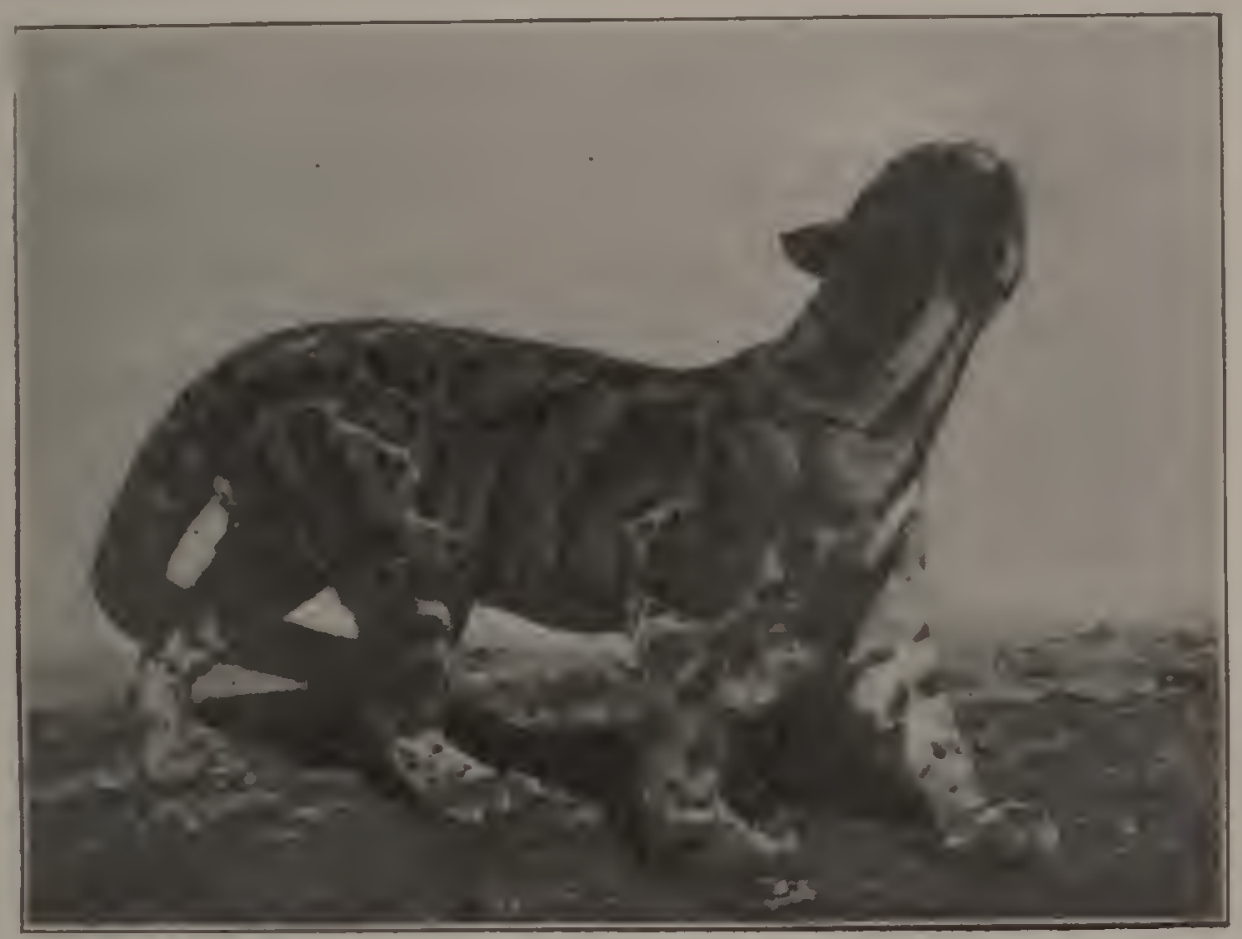

THE CLOUDED LEOPARD.

The Common Ocelot (Felis pardalis) is a native of Mexico, Central and South America, and occasionally those parts of the United States bordering on Mexico. In the desolate region lying along the Rio Grande in Texas, known as the "brush country," it is by no means uncommon. It is a beautiful animal, not much larger than the domestic cat. 
Like all the smaller members of the cat family, it climbs trees with great agility and lies in wait among the branches for its prey.

The Brazilian Ocelot (Felis chibigouazou) is considerably larger, and has a conspicuously large head, much more yellow in color then the rest of the animal. Several other species of small cats range from Mexico southward through tropical America. Among these the Eyra ( $F$. eyra) and Yaguarundi ( $F$. yaguarundi) have peculiarly long, flattened heads, and short legs, which cause them to look much like large weasels.

A number of others are found in Asia and Africa, of which the Serval (Felis serval), the Caracal ( $F$. caracal), the Fishing CAT ( $F$. viverrina), the Javan Cat ( $F$. javanensis), and the Golden CAT ( $F$.temmincki) are at times represented here.

The Spotted Hy Æna (Hyana crocuta), the Striped Hy ena (H. striata), and the BROWN HyenA (H. brunnea) constitute the family Hyanida. Of some of these, specimens will usually be seen in the Garden. They are readily distinguished from the dogs, which they somewhat resemble, by the excess of length in the fore over the hind limbs. Their molar teeth are unusually strong, and the jaw muscles are very powerful, thus enabling them to crush with ease large bones, which they devour.

The Striped Hyæna inhabits both Africa and India, and presents a marked appearance by reason of a mane or crest of hair, running the length of the spine, which it has the power to raise at will, probably for the purpose of increasing its apparent bulk and giving to itself a more frightful appearance, thereby deterring from an attack those enemies which would otherwise overcome and destroy it. It is more cowardly in disposition and solitary in habit than the Spotted Hyæna, which is confined to the southern part of Africa.

The Bornean Sun Bear (Ursus malayanus) and the Himalayan Bear (Ursus tibetamus) belong to a group of the Ursida known as sun bears, from their favorite habit of basking in the sun.

The Sloth or JUNGLe Bear (Melursus ursinus) frequents the thick jungles of India. 


\section{No. 3I.-THE ELK PEN.}

EAST of the Carnivora House is a large enclosure, to which the elk have recently been moved.

The AMERICAN ElK or WAPITI (Cervus canadensis) is the largest of the true deer, old bulls often reaching a weight of seven hundred pounds or more. As with all deer, the antlers, which are largely developed in this species, are shed every year, late in the winter or early in spring. The new

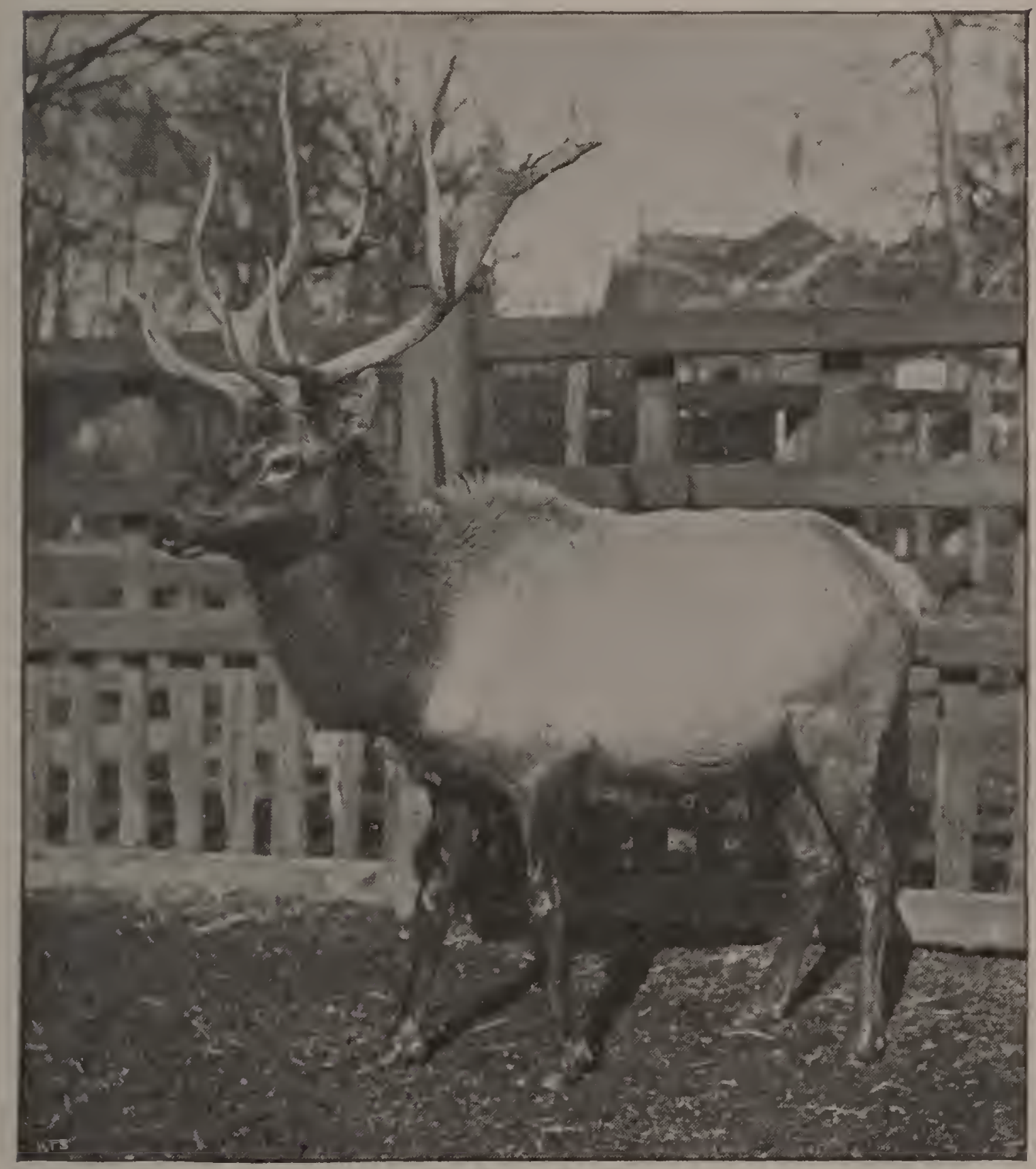

THE AMERICAN ELK. 
growth begins about April, and requires ten or twelve weeks for its completion. The antler is built up by a deposit of animal matter and mineral salts carried by the blood, and is almost identical in composition with ordinary bone.

In all deer except the reindeer and caribou, antlers are borne only by the male.

The wapiti ranged originally all over the United States and a large part of Canada; fitty years ago a few were found in the mountains of western Virginia and Pennsylvania, but civilization has gradually driven it, like the buffalo and the Indian, to a few fastnesses in the far west, where they yet make a stand before the final extermination which seems inevitably to await them. At the present time they are found only in the Rocky Mountains. In the Yellowstone National Park, where all animals are protected by law, they abound. They are readily kept, living on almost any kind of vegetable food, and are hardy and little liable to disease. Save in exceptional cases, and during the season of rutting, they are tractable and easily managed.

It is a significant fact, illustrating the great principle of inheritance in animals, that the only species of ungulates from the western part of the American continent which have yet been successfully domesticated east of the region of the great plains, are the elk and the buffalo, and in each of these cases their progenitors, but a few generations back, ranged nearly, if not quite, to the Atlantic coast.

\section{No. 33.-THE RACCOON TREE.}

A TALL honey-locust tree just outside the western entrance to the Small Mammal House has been surrounded by a fence and converted into a raccoon pen. The best known of these distincly American animals is the one common in the eastern United States, (Procyon lotor). They resemble in diet, and in many points of structure, the bears, and have been placed by some systematists as a sub-family of the group. They are generally classed, however, as a separate family, Procyonida, of carnivores. Their range is almost universal through the United States, from the latitude of Massachusetts southward. They are subject to considerable variation in color-albinos being not uncommon. A specimen formerly in the collection, from Alabama, was of an orange-yellow, shading into a 
deeper hue on those parts where the animal is normally black. They are easily tamed, and make playful pets.

Another species is the Crab-Eating Raccoon ( $P$. cancrivorus) of South America.

A usual result of attempting to reproduce in zoological gardens the exact surroundings of animals in their life under nature, is well illustrated by this enclosure, in which natural conditions have been so completely imitated, that probably not one visitor out of a hundred ever sees a raccoon. Those occupying it pass their whole time during the day hidden from view in the hollow logs, or asleep among the upper branches of the tree.

\section{No. 30.-THE SMALL MAMMAL HOUSE.}

THIs building was erected in 1898 , partly upon the foundation of the old Monkey House, and contains mammals of small size, belonging to a variety of groups.

The Viverride is a large family of carnivorous mammals of small size, all resembling more or less the civets in appearance and habits; they are of active and graceful movements, many of them living much among trees; all feeding upon smaller quadrupeds, birds, eggs, and reptiles. They chiefly inhabit Africa and southern Asia, two species being found in Europe.

Among them are the African Civet (Viverra civetta), the Burmese Civet ( $V$. megaspila), the Indian Civet (Viverricula indica), the Common Genet (Genetta vulgaris) of southern Europe and Africa, the PALM CAT (Paradoxurus niger), the Common Paradoxure ( $P$. typus), the Two-spotted PARADOXURe (Nandinia binotata), the BinTURONG (Arctictis binturong) from Malacca, the Mongoose or Gray ICHNEUMON (Herpestes mungo) from India and the surrounding islands, the Egyptian ICHNEumon ( $H$. ichneumon), the Dusty ICHNeuMON ( $H$. pulverulentus) from South Africa, and the beautiful Civet CAT or Ring-tailed BAssaris (Bassaris astuta) of Texas and Mexico. It is probable that the latter animal possesses affinities which ally it more closely with the coatis and raccoons than with the Viverrida, among which it has sometimes been classed. 
The ichneumons are fierce and blood-thirsty little animals, and a number of the common Indian species were imported a few years ago into the island of Jamaica, to rid the colony of the enormous numbers of rats which infested the plantations of sugar cane. The experiment seems to have been successful, as the animals have become fully acclimated, but in addition to the rats they have exterminated numbers of the native birds as well.

The coati will be readily recognized by its long, pointed snout. The two best known species are the WHITE-NOSED Coati (Nasua narica) and the Ring-Tailed Coati ( $N$. rufa),

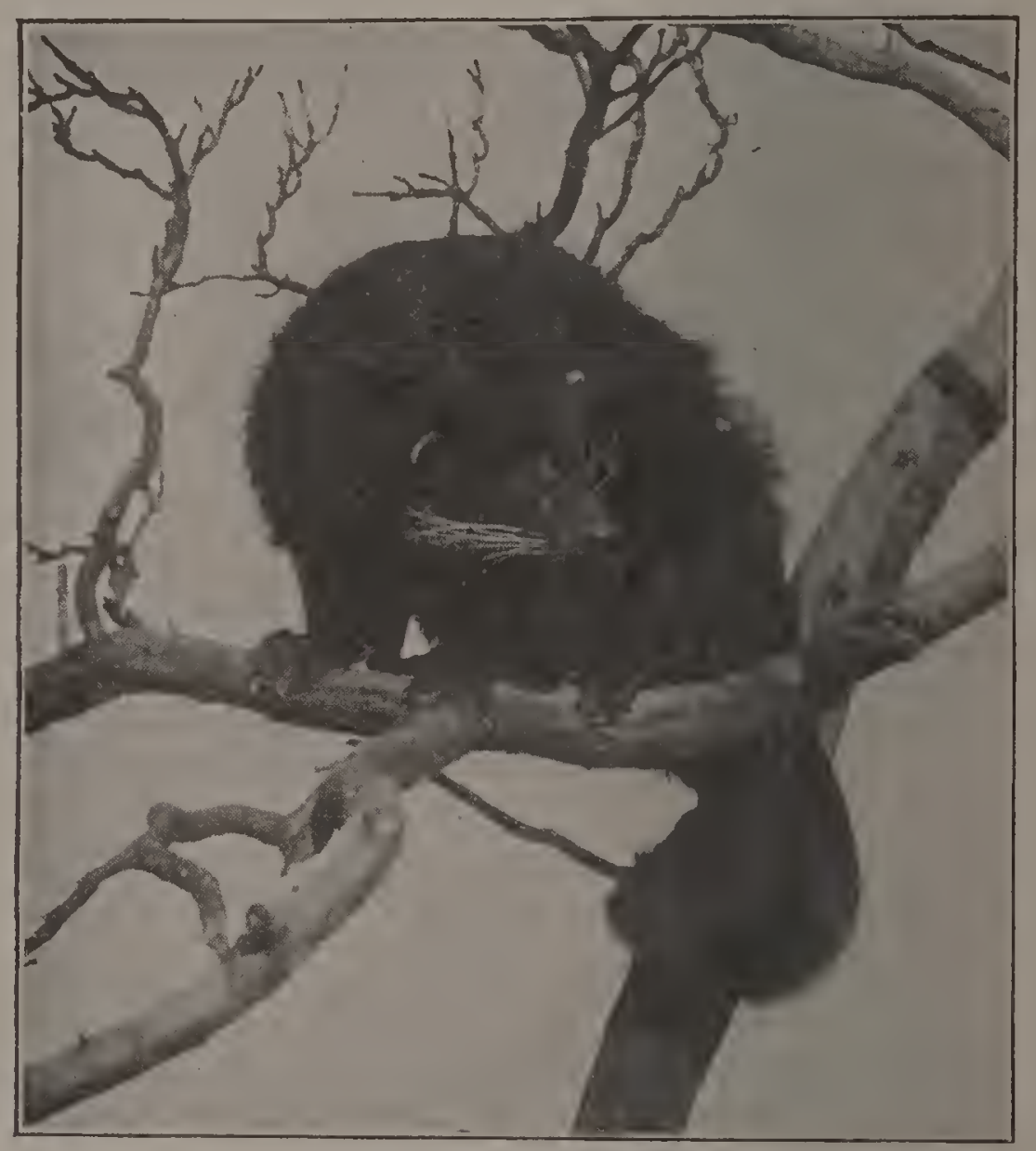

THE BINTURONG.

which range from Mexico through Central into South America; a pair of the first-named species, now in the collection, were taken near Laredo, Texas. These animals are allied by many points of structure to the bears and raccoons, and have been placed in the same family as the latter.

The KinKaJOU (Cercoleptes caudivoluulus), an inhabitant of sub-tropical America, is a very pretty member of this group. It is of gentle disposition and makes an interesting pet. 
Another large family of the smaller carnivora is the Mustelidle, which are largely represented in the New World; most of the fur-bearing animals, such as the otter, mink, sable, marten, and skunk being found within its limits. Some of the South American forms, as the TAYRA (Galictis barbara) and Grison ( $G$. vittata), and the Indian Ratel (Mellivora indica), which require artificial warmth in winter, are kept in this building.

The order Insectivora is not easy to define, as its members present such a diversity of characters that most of them have at times been placed in other orders. They are all of small size, and feed chiefly on insects and other invertebrates. A familiar example is the common mole. A rare and curious member is the Solenodon (Solenodon cubanus), from Cuba, nearly related to the shrews. Another strange form, the TENREC (Centetes ecandatus), comes from Madagascar. A better known insectivore is the Common European HedgeHOG (Erinaceus europeus). This curious little animal is found in almost all parts of Europe, in the colder portions hibernating through the winter months.

Few articles of food come amiss to the hedgehog, although its tastes are mainly carnivorous, - worms, insects, moles, small mammals, birds, and eggs being its chief diet, while in many parts of Europe the common people have a strange belief that it sucks the milk of cows when they lie down in the pasture or the barn-yard, of course, without foundation in fact.

The Rodentia is a very large order, characterized by the absence of canine teeth and the development of the incisors to so great a degree that they resemble chisels, and are used by the animal for the purpose of cutting wood and other hard substances, from which is derived their name-Rodentia or gnawers. Representatives of this order are found all over the world, North America having a large proportion of the whole number of species. Many of the occupants of this building belong to this group; among them are generally the Punctated Agouti (Dasyprocta punctata) from Central America, the Golden Agouti ( $D$. aguti), the Mexican Agouti ( $D$. mexicana), the Olive Agouti or Acouchy ( $D$. acouchy) from South America and the IVest Indies, the PACA or Spotted Cavy (Calogenys paca), and Fournier's Capromys (Capromys pilorides). 
The African Porcupine (Hystrix cristata), the Malaccan Porcupine (H. longicauda), the Javan Porcupine ( $H$. javanica), the White-HAIRED PORCUPINE (Erethizon dorsatus), and the Yellow-HAiRED PORCUPINE (E. dorsatus epixanthus) - the two last from North America-are all quiet, retiring rodents, living on roots and vegetables or the bark of trees. The spines which take, in part, the place of hair in the porcupine, are loosely rooted in the skin, and readily come off in the mouths of such animals as may attack them, thus forming a terrible means of defense to the animal. The ease with which these spines are detached has, without doubt, given rise to the fable that the porcupine is able to shoot forth its quills, like arrows, against its foes.

The African Brush-tailed Porcupine (Atherura africana) and the Brazilian Tree Porcupine (Coendu prehensilis) are also kept here.

THE VISCACHA (Lagostomus trichodactylus), a burrowing rodent from La Plata, closely related to the chinchilla, is stated by Mr. Darwin to have the curious habit of piling up around the mouth of its burrow all objects of a hard character which may be found in the neighborhood. So marked is this peculiarity that travelers, losing some small article upon the road, retrace their steps and examine every viscacha hole in the vicinity, generally with the result of finding the missing object.

The Capybara (Hydrocharus capybara) and Coypus (Myoptamus coypus) are natives of South America, and are of somewhat similar habits to the beaver and muskrat,- -like them belonging to the order of rodents. The capybara is much prized by the natives for its white, delicate flesh, while from the coypu is obtained the fur known as "nutria," formerly much used in the manufacture of beaver hats. A small colony of coypus is maintained in the creek behind the deer park.

The Vulpine Phalanger (Phalangista vulpecula) and the Yellow-Bellied Phalanger (Petaurus australis) are small vegetable-eating marsupials (see page 44) from Australia; they live almost entirely among the trees and are strictly nocturnal, being found in the daytime with heads bent down and noses stowed away between their forefeet. The burrowing marsupials are represented by the RABBIT-EARED BANDICOOT (Thylacomys lagotis.) 
Another interesting marsupial from the same region is the HAIRY-NOSED WOMBAT (Phascolomys latifrons). They are slow, sluggish animals, somewhat resembling the badger in appearance. They burrow in the ground and spend the day in strict retirement, coming out to feed only at night. In conformity with their natural habit, those in the Garden rarely awake until late in the afternoon. They feed altogether on vegetable substances, and delight in picking the tops out of a bunch of clover hay.

Other species are the Common Wombat ( $P$. mitchelli) and the Platyrhine Wonbat ( $P$. ursinus), both of which have been exhibited on previous occasions.

The Common Opossum (Didelphys marsupialis) ranges from the latitude of southern Massachusetts to the lower part of Brazil, and is the only representative in North America of the marsupials. The opossums belong to the carnivorous branch of the order, although their diet is very varied, consisting of small birds, mammals, reptiles, and eggs, as well as of fruits, buds, and grain.

They live generally in the hollow of a tree, where the female produces as many as fifteen young at a time, breeding several times in the course of a year. The characteristic pouch of the order is well developed in these animals.

They have a very prehensile tail, and are also distinguished by the peculiarity of their dentition, which consists of ten incisors, two canines, and fourteen molars in the upper, and the same, with two incisors less, in the lower jaw, or fifty teeth in all.

A number of opossums are found in South America, more or less resembling this species, though of smaller size. The collection has at times contained specimens of DERBY's Opossum ( $D$. derbiana), the Quica Opossum ( $D$. quica), the Ashy Opossum ( $D$. cinerea), and others.

The Indian Fruit Bat (Pteropus medius), known also by the names of rousette bat and flying fox, are now rarely seen in zoological collections, as their importation into the United States is forbidden by Act of Congress. They belong to the order Chiroptera. They exist in large numbers in India and the neighboring islands, where they grow to a very large size, the expanded wings sometimes measuring four or five feet from 
tip to tip. Sir Emerson Tennent gives the following account of some of their habits :-

"A favorite resort of these bats is to the lofty India-rubber trees, which on one side overhang the Botanic Garden of Paradenia, in the vicinity of Kandy. Thither for some years past they have congregated, chiefly in the autumn, taking their departure when the figs of the Ficus elastica are consumed. Here they hang in such prodigious numbers that frequently large branches give way beneath their accumulated weight.

"Every forenoon, generally between the hours of 9 and II A. M., they take to wing, apparently for exercise, and possibly to sun their wings and fur and dry them after the dews of early morning. On these occasions their numbers are quite surprising, flying as thick as bees or midges.

"After these recreations they hurry back to their favorite trees, chattering and screaming like monkeys, and always wrangling and contending angrily for the most shady and comfortable places in which to hang for the rest of the day protected from the sun.

"The branches they resort to soon become almost divested of leaves, these being stripped off by the action of the bats attaching and detaching themselves by means of their hooked feet. At sunset they fly off to their feeding-grounds, probably at a considerable distance, as it requires a large area to furnish sufficient food for such multitudes." - Natural History of Ceylon.

When at rest, the fruit bat hangs head downward, by one foot, wrapping itself tightly in the folds of its wings.

They are also found in Africa and Madagascar.

The Society has exhibited a number of specimens, but they cannot be seen to advantage in captivity, as during the whole of the day they hang, as described above, almost concealed from view within their wings.

The North American bats belong to the insectivorous branch of the order. The most common species in the Eastern and Middle States are the RED BAT (Atalapha borealis) and the LitTle BRown BAT (Vespertilio subulatus). In spite of the almost universal disgust with which they are regarded, they are harmless little beasts, and are of great service in destroying numbers of noisome insects.

Other mammals kept in this building during cold weather are the Peba Armadillo (Dasypus novemcinctus), the Hairy ARmadillo ( $D$. villosus), and the Six-BAnded Armadillo (D. sex-cinctus). The armadillos belong to the order Edentata-so called from the imperfections of their supply of teeth. They live in the warmer portions of the New World, from Texas to Patagonia. They burrow in the ground and live on worms and insects. 
The order includes, among existing animals, the armadillos, sloths, and ant-eaters of tropical America and Africa. Some of the largest of extinct mammals, of which remains have been discovered, as Glyptodon, Mylodon, and Megatherium, were also edentates-the first having been a sort of gigantic armadillo ten feet long.

The Giant Ant-eater (Myrmecophaga jubata), the TA. MANDUA ANT-EATER ( $M$. tetradactyla), living entirely on ants, which they procure by means of a mucilaginous saliva covering the tongue; Hofranan's Sloth (Cholopus hoffmani), the Two-toed Sloth ( $C$. didactylus), and the Three-toed Sloth (Bradypus tridactylus), strange animals which pass their life in an inverted position, swinging, back downwards, by their long claws from the trees from which they devour the leaves and tender twigs, are among the most remarkable of this order of beings.

Recent discoveries of fossils at Port Kennedy, on the Schuylkill river, have shown that in a geological period preceding that in which we live (the Pleistocene), when the climate of northern regions was much warmer than at present, sloths belonging to species now extinct were among the commonest inhabitants of Pennsylvania.

Leaving the Small Mammal House, the visitor passes the old mansion, "Solitude," erected in I 785 by John Penn, a descendant of the founder of the Commonwealth, and now occupied by the offices of the Society-and descending a flight of steps turns to the left by

\section{No. 4.-THE BEAVER POND.}

The American Beaver (Castor fiber canadensis) has been so valuable to commerce in times past, that much has been written of its habits, and volumes have been filled with marvelous tales of the intellectual feats which have been revealed to wondering authors. It is too often the case, however, in popular natural science, that much nonsense of almost superstitious character has passed accepted into animal life-histories, with painfully misleading results. There is little doubt that such has been the case here; the intelligence of the beaver being of the primitive kind which bears relation only to the common and most pressing needs of life, while in the higher grade of reasoning power which leads its 
possessor into ready adaptation to new conditions, he is strikingly deficient and is really a dull and stupid animal. The Beaver Pond at the Garden affords, perhaps, as good an opportunity as is possible, in confinement, of watching the habits of these animals, - the rough dome-shaped structure of mud and sticks on the island being the far-famed beaver hut, built by the animals themselves out of the natural materials. In a state of nature these huts are generally built on a small stream where the beavers have constructed a dam, deepening the pond sufficiently to keep the water from freezing to the bottom, so that they can get out under the ice during the winter. Most of their work is done during the night, but towards the hour in the afternoon when they are accustomed to be fed they may often be seen swimming about the pond and disappearing with a flap of the tail as they get within diving distance of the entrance to the hut.

Their food is purely vegetable, consisting mostly of the bark of trees and the roots of aquatic plants. They formerly ranged over the whole of North America, but have long since been almost exterminated in the Southern, Middle, and Eastern States, and are rapidly approaching this condition even in the far west.

Our beaver is so nearly identical with that of Europe, that it is questionable if there is even a varietal distinction.

\section{No. 5.-THE BEAR PITS.}

THE question as to the number of species of bears which inhabit North America cannot yet be regarded as fully settled, but for the present purpose it is enough to name the Polar Bear (Ursus maritimus); the Grizzly Bear ( $U$. horribilis); the BLACK BEAR (U. americanus); and the CINNAMON BEAR ( $U$. cinnamomeus). Alaska contains several more or less distinct forms, chiefly of the grizzly type, which reach a size far exceeding that of any others now known to exist, and perhaps equalling the extinct cave bear. The grizzly ranges through the whole Rocky mountain chain and the mountains of the Pacific coast, but in all this region they are now comparatively scarce; those from California being somewhat darker in color and reaching a larger size than those to the eastward. The bears known to hunters by the various names of "range bear," "bald face," "silver tip," and "cinnamon" are all of this species. 
The black bear is found almost all over the country, together with what is called the brown bear, which is merely a color variety of the former species, cubs of both colors being sometimes found in the same litter. The true brown bear is the Ursus arctos of northern Europe and Asia-an animal which presents many points of likeness, and is nearly related to our grizzly. The cinnamon bear is confined to the western parts of the United States.

The Ursida, or bears, all walk on the sole of the foot, or are what is termed plantigrade, and with the exception of the grizzly and polar bear, climb trees with great facility. The diet is much mixed, being indiscriminately animal or vegetable; strange to say, considering their bulky proportions, at certain seasons their food consists largely of snails and various insects.

They are distributed throughout the Northern Hemisphere - but one true bear having yet been found south of the equator.

In the large cage just behind the bear pits will be seen the Himalayan Bear (Ursus tibetamus). The male of the pair now in the collection is an albino.

The walk leading to the Monkey House has rows of cages on each side, the contents of which are constantly changing. A considerable variety of owls are, however, always to be found among them.

The Great Eagle Owl (Bubo ignavus) of Europe.

The Great Horned Owl (Bubo virginianus), North America.

The Screech Owl (Scops asio), North America.

The Barred Owl (Syrnium nebulosum), North America.

The Short-eared Owl (Brachyotus palustris), North America, Europe, and Asia.

The Snowy Owl (Nyctea nivea), Arctic regions.

The Barn Owl (Strix flammea americana), United States.

The Acadian Owl (Nyctale acadica), British America.

Whitney's Owl (Micrathene whitneyi), Arizona.

The Javan Fish Owl (Ketupa javanensis), Java.

Until within a few years, no ornithologist has doubted the close relationship of the owls to the other so-called "birds of 
prey," and they have usually been classed as a family, Strigida, of the order Raptores.

Recent observations on the anatomy of birds have, however, shown that the resemblance is but a superficial one, and is slight in comparison to the differences in internal structure, and the owls are now regarded as a distinct order Striges. The hawks, eagles, and vultures together compose the order Accipitres.

The owls are mainly of nocturnal habits, their eyes being adapted in structure to see in the dark, and the soft, downy plumage with which they are generally clothed, enabling them to steal with noiseless flight upon the small birds, mammals, and reptiles which form their food.

They range generally throughout the world, differing somewhat in habit, and greatly in size, and number nearly two hundred species.

The American barn owl, in rural districts commonly known as "Monkey-faced Owl," is one of the most curious of the group. It abounds in the Southern States, and is frequently found as far north as New Jersey, but its habit is so strictly nocturnal that it is little known to the world at large, even where the bird is common. Owls closely similar are found in almost all parts of the earth.

The large white or snowy owl is common to the more northern parts of both hemispheres. It moves somewhat south in winter, rarely getting below the latitude of New York.

The coloration of the owls is generally indistinct, owing to the downy nature of their plumage, and is subject to an infinite amount of variation.

A number of burrowing owls (Speoyto cunicularia), are usually to be seen in one of these cages. These little birds abound on the great plains wherever prairie dogs or gophers are plentiful, their favorite habitation being the deserted holes on the outskirts of the villages. They are found also in South America.

At times certain hawks are kept here. Their description will be found on page 6r, under Birds of Prey.

\section{No. 3.-THE MONKEY HOUSE.}

THE building formerly occupied by the monkeys being contracted in size and ill-ventilated, was for many years the cause of complaint from visitors and of annoyance to the 
management of the Garden. The result was the planning and erection of the present house, which was opened in the summer of I $\$ 96$. Its inside measurements are one hundred and eleven by fifty-six feet; it contains nine large cages, with corresponding ones on the outside for summer use. A feature of the building is a conservatory, nearly the full length of the structure, on the side opposite to the cages.

The monkeys of the Old World, or of Africa, Asia, and the Malayan Islands, have been arranged by naturalists in one great group called Catarrhini, while those of the New World constitute another group known as Platyrrhini. Two hundred and fourteen distinct species of monkeys and apes are recognized by the latest authorities; of these one hundred and twenty-eight belong to Africa and Asia and eighty-six to America. The two groups are very well marked in zonlogical characters, the most constant of which is that from which they derive their name. In the Catarrhini the septum, or cartilage dividing the nose, is narrower at the bottom than at the top, so that the nostrils converge towards the bottom, while in the Platyrrhini the cartilage is of the same breadth throughout and the nostrils are therefore parallel. The dentition of the first group is the same as that of man, being eight incisors, four canines, eight premolars, and twelve molars.

Monkeys are omnivorous in their food habits. For the most part they live on fruits, buds, tender leaves, and roots, though many of them eat also insects, small birds, and reptiles.

Apes and monkeys are classed in the same order-Primates - as man, the correspondence in structure being very close, amounting in some of the higher groups to modifications only of form. All the man-like or Anthropoid Apesthe Gorilla and Chimpanzee of Africa, and the Orang and Gibbon of India-belong to the first division. These apes can be captured only when young, and as they are difficult to acclimate, they are by no means common in menageries. The longest period for which any of them have lived in our gardens, has been four years for the orang, and six and a half years for the chimpanzee.

The Chimpanzee (Anthropopithecus troglodytes) is most commonly found, in company with its larger relative, the gorilla, on the west coast of Africa about the region of the 
equator, but is known to range far eastward to the sources of the Nile, in Uganda, and about Lake Tanganyika.

Divesting the chimpanzee of the many doubtful, if not fabulous qualities with which it has been endowed by imaginative travelers, it remains a huge ape, attaining in the adult male a height of nearly five feet, devoid of a tail, possessed of a very considerable degree of intelligence, and having the ability to walk nearly erect, supporting itself by occasionally touching its knuckles to the ground or some upright means of support.

They live together in small bands of half a dozen and are said to build platforms among the branches, out of boughs and leaves, on which they sleep; their diet is chiefly frugivorous, and they are exceedingly mild in disposition, readily becoming friendly and seeking the society of man when placed in confinement.

These apes are looked on by the natives of their country as being degenerate members of their own tribe. A native name, "Engeco," means " hold your tongue," and evidently had its origin in the common belief that they refuse to speak purely from laziness, and in the fear that if their possession of the faculty should be discovered, they would be set to work with the strictly bipedal inhabitants of the same region.

The Orang-utan (Simia satyrus) is indigenous only to Borneo and Sumatra. They never attain the height of the chimpanzee, but are of heavier build and greater in extent of arm. Mr. Wallace gives as the maximum height of seventeen specimens, four feet and two inches from crown to heel, with a distance across the outstretched arms of seven feet eight inches.

They are of a sluggish and cautious disposition, and rarely come down from the trees. The mental characteristics of these apes have been stated elsewhere, by the author, as follows:-

"Between the orang and chimpanzee there is a marked difference in moral qualities. The latter is full of life, vigor, vivacity; lively and child-like in disposition, enjoying life to the full, and taking interest in all that goes on about it. Quite the reverse with the orang: it is slow, sluggish, and calculating; philosophically indifferent to everything but its immediate wants, voluptuary and stoic in one; life is only for the means of living, and life itself is hardly worth the pain of an exertion. For hours it will lie wrapped in a blanket, close to the front of the cage, lazily following with its eyes the movements of any person who comes within its range of vision, or slowly blinking at a straggling fly upon the glass.__ - American Naturalist. Vol. XVII. 
It has been stated by travelers that when the weather becomes cold or rainy, the orang wraps itself in large leaves, by way of protection. It is curious to observe that this habit is carried into captivity, for if a blanket is left in the cage, the animal will at once envelop itself so completely that nothing can be seen of it but its bright eyes peering out from under the folds.

The Dyaks of Borneo call the orang by several names, the most common being "Mias." The old males, to whom a huge callosity which grows out on each cheek, together with a long red beard which covers the chin and throat, gives a hideous appearance, are known as "Mias-papan."

The specimens of these apes which are usually exhibited in zoological collections, are young, ranging from three to six or eight years old. Their development is slow, as it is not supposed that they reach maturity until about fifteen years of age. When old they generally become morose and vicious in disposition.

The Gibbons are least in size and lowest in organization of the anthropoid apes; they inhabit parts of India, Malacca, and many islands of the Malayan region. They vary so interminably with age, sex, and locality that it seems hopeless to attempt to class them into species. Of those well known, the Active GibBon (Hylobates agilis) and the WHITE-HANDED GibBon $(H$. lar), have been shown in the collection.

Among the monkeys of the Old World which are commonly to be found in the building, is the ENTELLUS OR SACRED MoNkEy (Semnopithecus entellus) of India. This monkey is held in high respect by the human natives of its country, who call it "Hanuman," after one of their deities, and allow it the privilege of stealing, unmolested, pretty much anything to which it takes a fancy-a privilege which it soon learns to avail itself of on every occasion. Its life is held sacred, and under the native rule in India, capital punishment was inflicted for its destruction.

Other rare species are the Mitred Monkey ( $S$. mitratus), the Moor Monkey ( $S$. maurus), and the PURPLE-FACED MONKEY (S. cephalopterus).

The Vervet Monkey (Cercopithecus lalandi), the Green Monkey ( $C$. callitrichus), the Patas or Red Monkey ( $C$. ruber), the Lesser White-nosed Monkey ( $C$. petaurista), the 
Mozambique Monkey ( $C$. rufo-viridis), the beautiful Diana Monkey ( $C$. diana), Campbell's Monkey ( $C$. campbelli), the Mona Monkey (C. mona), the Malbrouck Monkey (C. cy. nosurus), the SoOTy MaNGaBEy (Cercocebus fuliginosus), the White-collared Mangabey ( $C$. collaris), and the WhiteCROWned Mangabey ( $C$. athiops) are all natives of Africa.

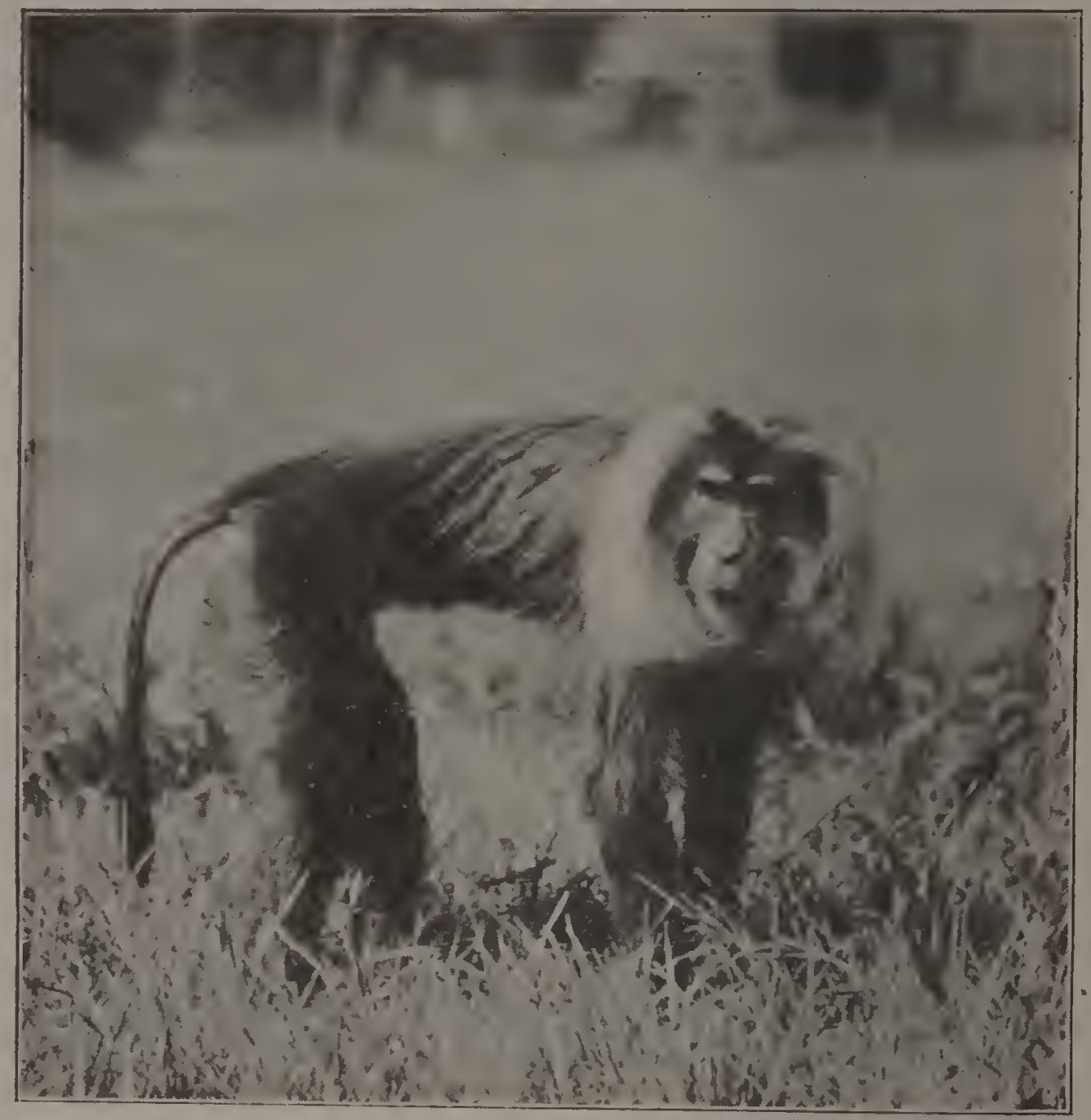

THE LION-TAILED MACAQUE.

The macaques form a large genus of monkeys, some of them of large and powerful build, and, for the most part, of savage and treacherous disposition. They are natives of Asia and the adjacent islands. Among them are the Common Macaque (Macacus cynomolous), the Pig-Talled Macaque ( $M$. nemestrinus), the rare Leonine MaCaQue ( $M$. leonimus) from Burmah and Yunnan, the Foriosan MaCaQue $(M$. cyclopis), the Rhesus Monkey ( $M$. erythraus), the Liontailed Macaque ( $M$. silenus), the Toque ( $M$. pileatus), the 
Bonnet Macaque ( $M$. radiatus), the Moor Macaque ( $M$. maurus), and the Brown MACAQUE ( $M$. arctoides).

The Japanese Monkey ( $M$. fuscatus) ranges further north than any other of the group, and the specimens in the Garden remain out of doors through the winter, thoroughly enjoying both cold and snow.

The Barbary Ape ( $M$. inuus) is the only member of the genus found outside of Asia, its home being North Africa. A few individuals are also found about Gibraltar, in Spain, but it is probable that they were introduced there originally through the agency of man.

ThE BlaCk APE (Cynopithecus niger), from the Philippine Islands, is related to the last genus.

The genus Papio forms the group known as baboons, among which are some of the largest and most fierce of the order. The HAMAdRYAS (Papio hamadryas) comes from Arabia and North Africa, while the Chacma ( $P$. porcarius), the Doguera Baboon ( $P$. doguera), the Guinea Baboon ( $P$. sphinx), the Mandrill ( $P$. mormon), the Drili ( $P$. leucophaus), and the ANUBis BABOon ( $P$. anubis) are natives of Africa. They can all be recognized by their long, dog-like noses, in some cases projecting beyond the lips.

Although these monkeys are coarse and brutal in their behavior towards man, they are capable of *a high degree of attachment among themselves.

A remarkable instance of this is given by Brehm, who once saw a troop of baboons crossing a valley; while so doing they were attacked by his dogs, and fled up the hills, leaving behind one young one, which, unable to run away, had climbed a rock in the middle of the valley. Those on the hillside deliberated for a time, and finally a large male returned to the spot, drove off the dogs, picked up the young one, and retreated with it in safety.

The American monkeys differ in many respects from the preceding group; in dentition, which in the Cebida, including all but the marmosets, has one premolar tooth added on each side of the jaw; in the absence of a thumb in almost all the members of one large genus (Ateles); in the entire absence of the cheek-pouches and the callosities on the haunches, which are so conspicuous in most of the Catarrinini and in the presence of a highly prehensile tail in several genera. None of them attain the size of the largest of the first group, and they are generally more tractable in disposition. 
The howlers form a remarkable group in which the vocal apparatus is modified in a manner such as to pour forth a volume of sound so great as to suggest their distinctive name. The Mantled Howler (Alouatta palliatus), Brown Howler (A. fuscus), Red Howler (A. senicula), and Black Howler ( $A$. niger) belong to this group.

The Grey Lagothrix (Lagothrix humboldti) and the Black SAKI (Pithecia satanas) are natives of Brazil. The males of the latter species have a thick beard covering the lower part of the face and the throat.

The Ateles or Spider Monkeys are characterized by the absence of a thumb, although in several species it is present in a rudimentary condition; they have a prehensile tail, lined on the tip with a very sensitive skin, which answers the purpose of a hand in suspending themselves from the branches of the trees among which they altogether live. They are very delicate, and do not long withstand the severities of our climate.

The Black Spider Monkey (Ateles ater), the Brown Spider Monkey ( $A$. hybridus), the Chuva ( $A$. marginatus), the Marimonda ( $A$. belzebuth), and the Black-HANDED Spider Monkey ( $A$. geoffroyi) are usually to be seen here.

The Brown Capucin (Cebus fatuellus), the Weeper CapuCin ( $C$. capucinus), and the White-Throated CAPUCin ( $C$. hypoleucus) are all small monkeys of the kind usually trained for circus performances and organ-grinders. These, with the Ti-Ti or Squirrel Monkey (Saimaris sciurea), all belong to the family Cebida.

A rare and little-known member of the Cebida, a specimen of which has been exhibited by the Society, is the RED OUAKARI (Brachyurus rubicundus), from Brazil.

The Common Marmoset (Hapale jacchus), the Blackeared Marmoset (H. pencillata), the Pinche (Midas redipus), the Silky Marmoset ( $M$. rosalia), and Geoffroy's MarMOSET ( $M$. geoffroyi) are small and beautiful monkeys from the hottest parts of tropical America. They are frequently kept as pets, but being of frail constitution, they suffer from the slightest approach to cold, and it is hardly possible to keep them for exhibition. 
A curious genus of small monkeys of nocturnal habits is found in the interior of South America. They are gentle and timid in disposition, and pass most of the day in sleep. The Three-Banded Douroucouli (Nyctipithecus trivirgatus), is the most common of these monkeys.

The monkeys of the New World range from about twentythree degrees north to thirty degrees south latitude; the extreme northern point which they reach in the eastern hemisphere being in Japan, about forty-one degrees north latitude.

A considerable group of animals of curious organization, many of whose forms resemble apes, while others reach off towards the lower types of animals, constitutes the order Lemures-Lemurs or Half-apes. They are all nocturnal, live in trees, and feed on fruits, insects, and small birds and quadrupeds. They number some fifty species, and are native to south-eastern Asia, central Africa, and the island of Madagascar, which contains a large proportion of the whole number of species. Of those sometimes seen in the collectionthe Grand Galago (Galago crassicaudata) is from Mozambique, and the MONGOOSE Lemur (Lemur monooz), the Ring-Tailed Lenur ( $L$. catta), the Black Lemur ( $L$. macaco), the RufFed Lemur ( $L$. varius), and the WhiteFRONTED LEMUR ( $L$. albifrons) are all natives of Madagascar. The BLACK LEMUR is remarkable for the great difference which marks the sexes, the male being generally coal black, sometimes with a brownish tinge, while the female is of a light reddish or gray brown on the body, with a white ruff around the face. The SLow Loris (Nycticebus tardigradus) belongs to the tailless section of the group and is not uncommon in collections, while COQUEREL's DWARF-LEMUR (Microcebus coquereli), from Madagascar is more rare. Lemuroid animals abounded in the Eocene period, and out of them were undoubtedly developed the Primates and probably other onders.

\section{No. I2.-THE RESTAURANT.}

THE Restaurant is on the right of the prescribed route after leaving the Eagle Aviary, and offers to the hungry visitor, ample facilities for supplying his necessities.

Close by will be found the stand for donkeys. 


\section{No. 7.-THE ELEPHANT HOUSE.}

THIS building was completed in 1875 , and cost about $\$ 38,000$. It is one hundred and ninety-five feet long, and affords ample accommodations for many of the larger animals.

Immediately adjoining it is a large pond in which the elephants are bathed every afternoon during hot weather. Besides being a popular means of diversion to visitors, the use of water is a necessity to these animals; their skin being exceedingly porous, becomes readily clogged up if they are not kept clean, with the result of lessening the amount of perspiration, which is one of the chief means of removing waste matter from the system, and is absolutely necessary to a pure state of the blood.

A large proportion of the animals in this building belong to the order Ungulata, or hoofed animals, comprising those in which the nail grows around the ends of the extremities and envelops them in a horny sheath known as the hoof. Some of these have one or three toes developed, while another group has two or four toes equally complete, the others being rudimentary. For purposes of convenience, therefore, the existing ungulates have been classed into two sub-orders, the Perissodactyla, or odd-toed, as the horse, rhinoceros, and tapir, and the Artiodactyla, or even-toed, comprising all the split-hoofed animals, as deer, oxen, swine, \&c. They are all vegetable eaters, and are found in all but the Australian region.

The Wild Boar (Sus scrofa) of Europe, Asia, and Africa, the Javan Swine (Sus vittatus), the Red River-hog (Potamochorus porcus), and the ETHIOPIAN WART HOG (Phacochorus athiopicus) belong to the family Suidce, or Swine. The latter remarkable-looking animal has several tleshy protuberances on the face, looking almost like horns. It is believed that these warts have been developed by reason of their serving to protect the eyes from the upward strokes of the tusks in the desperate battles which the males wage against each other.

The peccaries are not true swine, but they do not depart widely enough to be entirely separated from the group. The Collared PECCARY (Dicotyles taracu) ranges from the south-western United States into South America, and the White-LipPed PeCCARy (D. labiatus) somewhat more southern 
in distribution, and confined to South America. They are savage little animals, and, as they herd together in considerable numbers, they are regarded as dangerous enemies by both man and beast. They are not difficult to domesticate when taken young, but the presence of a pair of dorsal glands, secreting an unpleasant fluid, which is apt to taint the meat after death, greatly lessens their value to man. The flesh in any case is tasteless and dry.

The enormous animals which form the order called Pro. boscidea, from the peculiar elongation of their nose into a

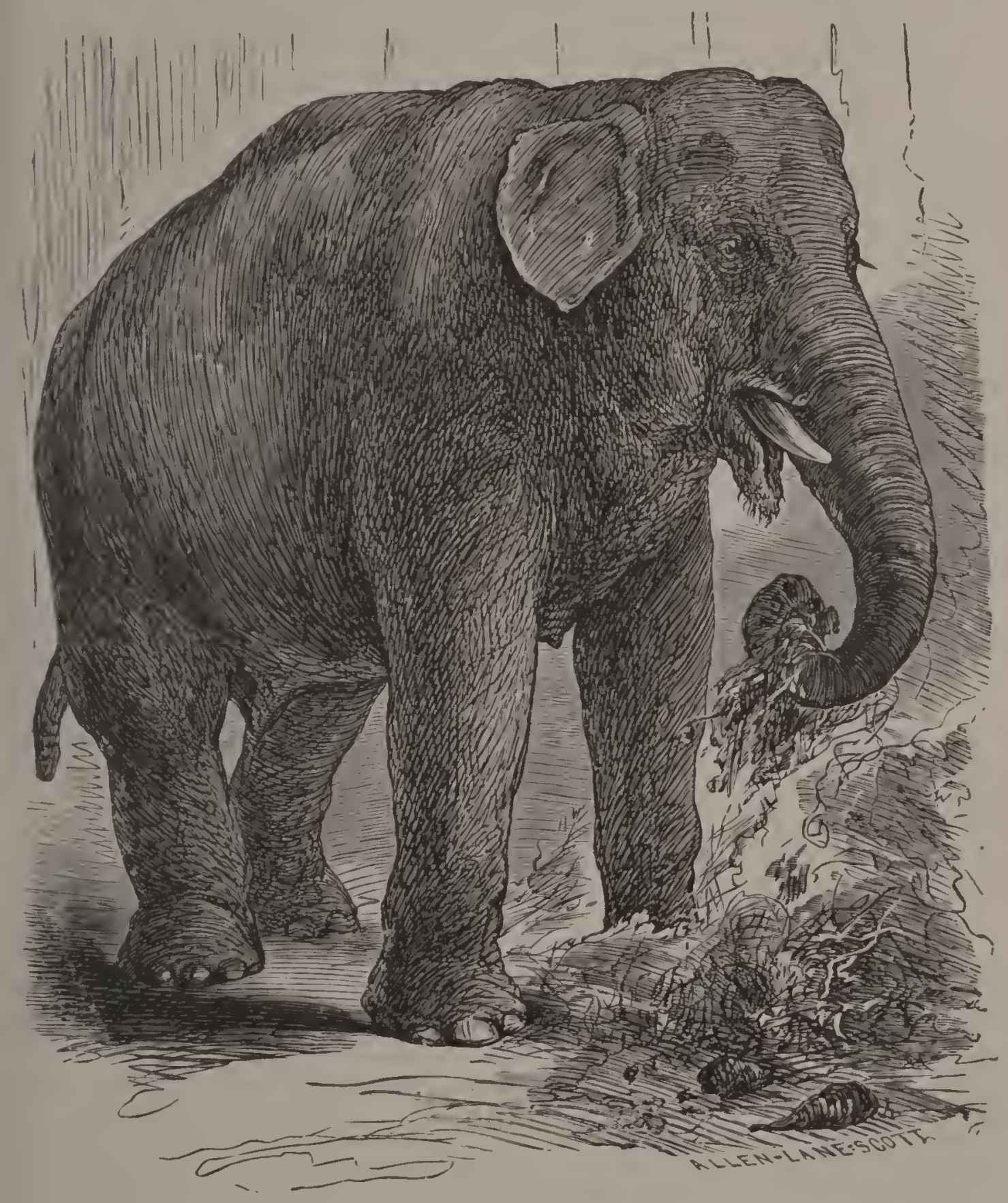

THE INDIAN ELEPHANT. 
proboscis or trunk, are found at the present time in the warmer parts of Asia, in the islands of Borneo, Sumatra, and Ceylon, and also in central and southern Africa.

There are two species, differing very appreciably, - the INDIAN ElEPHANT (Elephas indicus) has a concave forehead, comparatively small ears, and has four nails developed on the hind feet, while the AFRICAN ELEPHANT (Elephas africanus) has a rounder forehead, much larger ears, and has three nails on the hind foot instead of four. The pattern of the crowns of the molar teeth is also different. The incisor teeth, or tusks, as they are called, grow to an enormous size, but are rarely possessed by the female Indian elephant.

"BOLIVAR," the large male in the collection, was presented to the Society by Mr. Adam Forepaugh on the twenty-fifth of December, I888, and is probably the largest elephant in captivity, measuring nearly ten feet in height at the shoulder and weighing about ten thousand pounds. The other elephants at present in this building are "Empress," purchased in I 876, at which time she was about three years old, and "Kaiserin," presented in I902. The last was probably born about I 898 .

The elephant is in reality a smaller animal than is commonly supposed, careful measurements of large numbers in India showing that they average less than nine feet in height, and rarely exceed ten. They are believed to be fully grown at from twenty-five to thirty years of age. The ordinary life of the elephant is supposed to be about a hundred years, although in special cases they undoubtedly live much longer.

The fact is given, on the authority of Sir Emerson Tennent, that the British, after their capture of the Island of Ceylon, in I799, had in their service an elephant which was proved by the records to have served the Dutch during the whole term of their occupancy,-something like a hundred and forty years.

The elephant lives wholly on vegetable diet.

The Indian Rhinoceros (Rhinoceros unicornis). There are five or six species of rhinoceros found in A frica and Asia, the distribution of the animal being almost identical with that of the elephant. All the species, with the exception of this and the Javan rhinoceros, have two horns, one immediately behind the other.

Quite a number of fossil rhinoceroses have been discovered 
in the middle and later Tertiary, so that those now existing may be looked upon as the last of an expiring line, and they are, in fact, disappearing so rapidly that while some one of the A frican species is now and then available, it is doubtful if the Society will ever be able to replace "Pete," the huge male of the Indian species, who died in I90I, after spending twenty-seven years in the Garden.

The native country of the GIRAFFE (Giraffa camelopardalis) is the central and eastern part of Africa, from about the tenth or fifteenth degree of north latitude almost to the Cape; but in most parts of this vast region they are now scarce, few, if any, being found south of Mashonaland. They are found in small herds, browsing on the branches of such trees as may be within their reach. Their long legs unfit them for feeding on the ground, as it is a work of much difficulty for the giraffe, by straddling its fore legs widely apart, to get its nose down to the level on which it stands.

It is a ruminant, closely related to the antelopes. The horns, or protuberances on the head, are never shed, but are composed of solid bone, covered with skin like the remainder of the skull.

As with the elephant, the height of the giraffe is much over-estimated in popular opinion; it probably does not average over sixteen feet. They are very delicate in constitution, and in our climate require the most careful attention.

Of late years few giraffes have been shipped from Africa, and at the present time they are costly luxuries in collections which possess them.

At present the Society does not possess a hippopotamus, which was formerly kept in this building, but it is hoped that this want may be supplied, and a special and suitable building be erected for their care.

There are two species of the animal, one of small size, found on the west coast of Africa, and the better known one (Hippopotamus amphibius) - the River-horse of the ancientsfound in many of the African rivers. Being of great bulk, with disproportionately short legs, they are clumsy out of water, although they forage freely at night among the grain fields, where cultivation is carried on along the river banks, doing much damage, not only by the amount carried off in 
their capacious stomachs, but by the broad trail of crushed and broken herbage they leave behind them. They feed also on river grasses which grow along the water's edge, as well as on the bottom, on which their weight enables them to walk. The name of "river-horse" was suggested by a somewhat fanciful resemblance between the profile of the face and that of the horse-this is sometimes apparent when the animal is lying submerged in the water with no part visible but the frontal outline.

The South American Tapir (Tapirus terrestris), as before stated, belongs to the same division of ungulates as the horse and rhinoceros, though in appearance it somewhat resembles the swine. The natives of the regions which it inhabits consider it to be very good eating. It is fond of the water, diving and swimming with great ease, and is rarely found far from the banks of some lake or stream. Their common resort is the dense thickets of undergrowth, where they lie concealed from danger. D'Azara says of them :-

"It is also remarked that when the jaguar pounces upon them, they rush headlong through the thickest parts of the woods, until they force him to quit his hold, passing through narrow and intricate places. The Mborebi, indeed, never frequents a beaten road or pathway, but breaks and pushes through whatever it encounters with its head, which it always carries very low. It flies all danger, and anticipates it by means of its strong nocturnal vision and its acute sense of hearing."

There are several not very well defined species in South and Central America and one in south-eastern Asia. Of this species (Tapirus indicus) the Society exhibited a specimen some years ago. It is much larger than the South American form, and has a grayish-white patch marked out like a saddle-cloth over the back and sides from the shoulders to the rump-from this it derives its popular name of SADDLE-BACKED TAPIR.

\section{No. 8.-THE SEAL PONDS.}

THE seals are an order of carnivorous mammals, living mainly in the water, but at stated periods during the year leaving their natural element and remaining for several months above the water line. The Society has exhibited several species of these interesting animals. 
The Common or Spotted Seal (Phoca vitulina) is found in all the seas encircling northern Europe, Asia, and America, rarely being seen on our coast below Maine, except in winter, when it sometimes finds its way as far south as Chesapeake Bay. It is the type of the Phocide, or Earless Seals, of which it is the smallest. Like all seals, they live on fish, which in a state of nature they catch with great address. Quite a number of seals of this group have been shown in the Garden, one of which, a specimen of the Hooded SEAL (Cystophora cristata), was captured on the New Jersey coast near Long Branch.

Another rare species, examples of which have twice been exhibited, is the WEST INDIAN SEAL (Monachus tropicalis), formerly not uncommon throughout the Caribbean Sea, from which it has now disappeared with the exception of a few of the more remote islands and keys.

One of the ponds is occupied by a number of Gillespie's HaIR SEAL or SEA Lion (Zalophus califormiamus). This species is found in large numbers on the Pacific Coast of the United States; those in the Garden having been captured at the San Miguel Islands, off the coast of California, not far from Santa Barbara; they are common at Seal Rock, just outside of the entrance to the bay of San Francisco, and a closely allied species is found in the waters of the same latitude on the Asiatic side of the Pacific.

The differences between this species and the Northern SEA Lion (Eumetopias stelleri) are mainly in size, the latter growing much larger, and also in some details of the skull and teeth. The male hair seal, when adult, weighs three or four times as much as the female, and is provided with enormous canine teeth, with which they fight terrible battles at the season of rutting, often injuring each other severely; they are of a savage and dangerous disposition, and are ugly antagonists even to man.

They swim and float with great address, sleeping on the surface of the water; they remain at sea during eight or nine months of the year, coming out on shore in vast numbers at the season of breeding, where they remain in some cases as much as three months without food or water. On land they progress with more ease than is common with other seals, by a gait somewhat like the canter of a horse; they climb rocks easily, and throw themselves from a height of ten or fifteen feet into the water or on the rocks without damage-their 
tough skins and a layer of fat several inches thick, which lies immediately beneath, protecting them from injury. They are representatives of the family of eared seals (Otarida), all of which are of large size, and are readily distinguished by the possession of an external ear, which is never more than an inch and a half long and is rolled tightly in the shape of a cone. There are seven or eight species of these seals, all being confined to the Pacific Ocean, where they range from the Arctic to the Antarctic region, one species only being sometimes found up the Atlantic coast of South America as far as Brazil. The fur seals belong to this group; the undercoat of fur being very soft and thick in them, and supplying the seal-skin of commerce.

When fully adult the males are seven or eight feet long, and weigh from five to six hundred pounds; the females weighing not over a fourth as much.

Some years since the Society procured a number of the northern Elephant SEAL or SEA-ElePHANT (Macrorhinus angustirostris). These animals received much attention on account of their extreme rarity; the ones formerly in the possession of the Society being the only ones which have ever been captured alive for purposes of exhibition.

For many years the elephant seal was known to exist in the antarctic region of the Pacific, and about 1850 , they were observed in small numbers on some of the uninhabited islands off the coast of lower California. These were subsequently found to be quite distinct from the southern form. When adult, the males are usually from sixteen to eighteen feet long, although some have been seen nearly thirty feet in length and weighing probably seven or eight tons. The females are much smaller.

The peculiarity from which they derive their name is a. curiously elongated snout, which in the adult male reaches a length of eighteen inches, and somewhat resembles the trunk of an elephant.

They belong to the group of earless seals, and are the largest of marine mammals excepting the whale, although from the little that is known of their habits, they appear to be of a quiet and inoffensive disposition. The California species is nearly extinct, having been slaughtered for the oil and blubber which they yield in large quantities. 


\section{No. IO.-THE ANTELOPE OR DEER HOUSE.}

THIs building was completed in I877, and affords accommodation at present for a somewhat varied assortment of herbivorous animals.

Several species of zebra and quagga are found in Africa, and also of wild asses in south-western Asia. The most beautiful of all these, in pattern and shade of coloring, is BuRCHELL's ZeBRA (Equus burchelli), which ranges in large herds over the plains north of the Orange river, in Africa. The so-called Chapman's zebra comes from farther north,

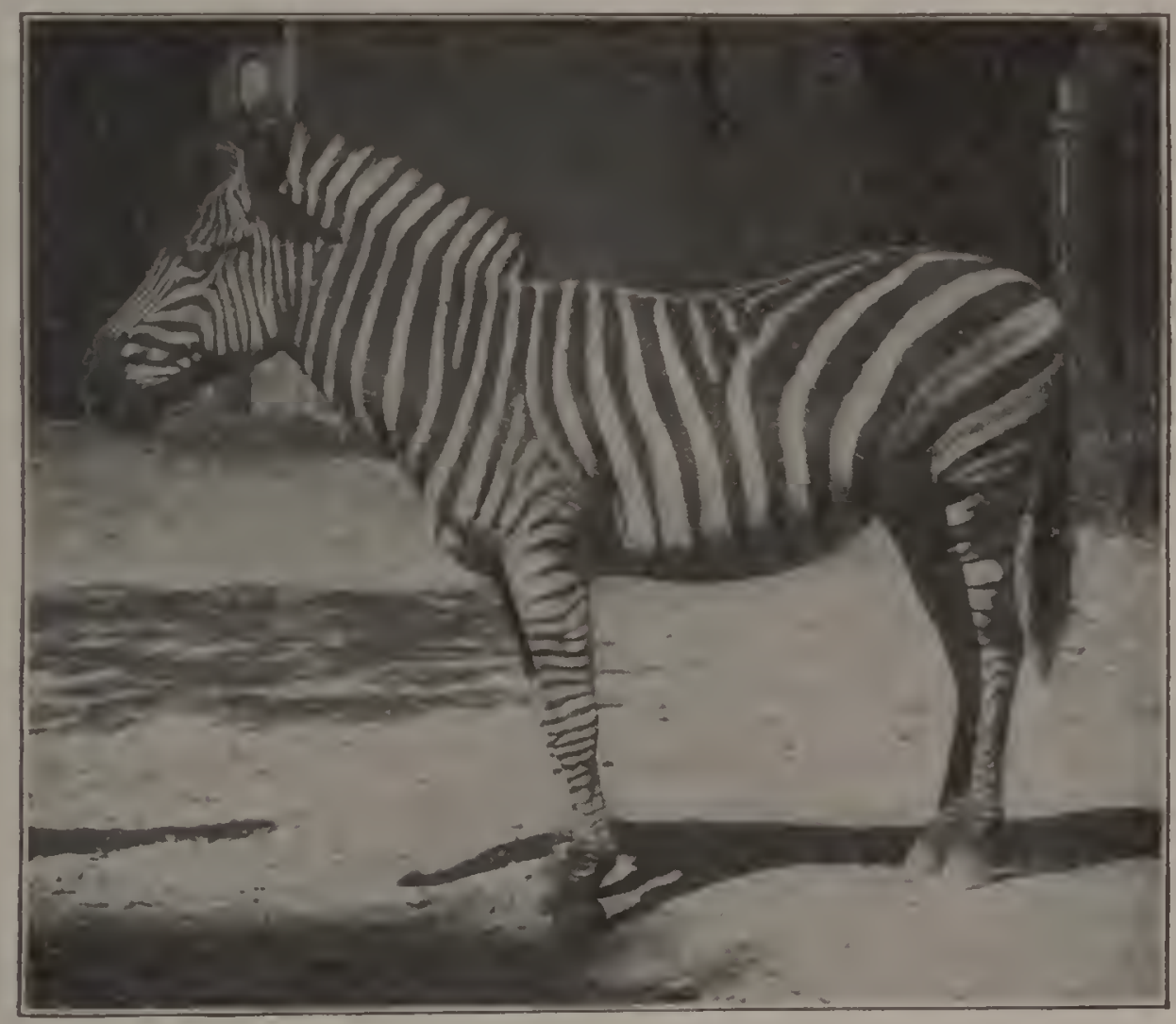

CHAPMAN'S ZEBRA.

and is probably of the same species. It is a well-known fact that some horses, especially those of a dun color, have indications of the spinal stripe and those on the inside of the legs, which are possessed by nearly all the wild species, which resemblance is held to indicate the relationship of the horse of the present epoch to some such antecedent form. A 
mouse-dun colored work-horse recently belonging to the Society had these stripes plainly marked.

Another zebra, formerly well known in menageries, is the Mountain Zebra (Equus zebra), in which the cream body color of the former species is replaced by white. This species inhabited the extreme south of Africa, in which population has increased to such an extent that the animal is now nearly extinct.

A FINE species of wild ass is found in central and southwestern Asia, with several not very well-defined varieties. A pair of the form inhabiting Persia (Equus hemionus onager) will be seen next to the zebras.

The Cape Buffalo (Bos caffer), is found over a large portion of Africa. The old bulls are marked by an extraordinary growth of the horns, which extend completely over the forehead, almost meeting in the middle line. They grow to a large size, and are so savage and vindictive in disposition that many experienced hunters regard them as the most dangerous game animals inhabiting Africa.

One formerly in the collection was of a variety found in north-eastern Africa ( $B$. caffer aquinoctialis).

The EI.ANd (Oreas canna). This truly magnificent animal is the largest of the antelopes, the great home of which is in Africa; this species being from the southern part. The antelopes are generally of small or medium size ; the eland, however, is frequently of the size and weight of a large horse. Like many antelopes formerly common, they are now rarely to be seen in collections.

The Oryx (Oryx leucoryx) is another of the innumerable tribe of antelopes inhabiting Africa. It is conspicuous for its long, slightly curved, and tapering horns, which, as it is exceedingly quick in its motions, it uses with much effect upon an enemy. The lion has more than once been met and pierced to the heart by these terrible horns when he thought to secure, without danger, an unresisting prey. The species is from the north of Africa.

Other members of the antelope family are the NyLGHale (Boselaphus pictus), often called in India the Blue Bull, the BRINDled GNu (Connochetes gorgon), the White-TAILEd GNU C. gnu), the Beisa Antelope (Oryx beisa), the Bubaline 
Antelope (Alcelaphus bubalis), the Sing-SING (Cobus unctuosus), the Sable Antelope (Hippotragus niger), the DorCaS Gazelle (Gazella dorcas), Persian Gazelle ( $G$. subgutturosa), and the Indian AnTelope (Antilope cervicapra). The gnus are found in large herds about the Orange river, in south Africa. The gazelles inhabit south-western Asia and northern Africa, and, being docile and of exquisite grace in proportions and movement, are much sought by the Arabs as pets.

The Harnessed Antelope (Tragelaphus scriptus) is marked on the body with white stripes looking much like a harness.

The Crowned Bush Buck (Cephalophus coronatus) is one of a group of small antelopes found in eastern and southern Africa, where they are known as DUIKERs. They are of shy and retiring habits, and rarely come out of the thick bush in which they live.

The Rusine or Sambur Deer, of which Cervus hippelaphus, from Java, and C. equinus, from the Malayan Islands, are examples, are found throughout the Indo-Malayan region, and are large and stately animals. THE AxIS DEER (Cervus axis), also from India, the NAKED-EARED DEER (Cariacus gymnotis), the RED BROCKET ( $C$. rufus), from South America, the Yucatan DeEr (C. toltecus), and the Muntuac or BarkING DEER (Cervulus muntjac) of India are also in this building during the winter.

A group of four or five small ungulates, nearly related to the deer, and found only in India and Malaysia, forms the family Tragulide-muis deer or chevrotains. None of them have antlers, but in place of these, as weapons, the males have a pair of projecting canine teeth in the upper jaw. These little deer never exceed twelve or fourteen inches in height at the shoulder. The collection has contained the Indian Chevrotain (Tragulus meminna), from India and Ceylon; the Javan Chevrotain ( $T$. javanicus); and $T$. stanleyanus, from Java.

The Great Kangaroo (Macropus giganteus).

The Red Kangaroo (M. rufus).

The Robust Kangaroo ( $M$. robustus).

The Derbian Wallaby (M. derbiamus).

Bennett's Wallaby (M. bennetti).

The Black Wallaby (M. ualabatus). 
The Rufous-necked Wallaby ( $M$. ruficollis).

The Short-Tailed Wallaby ( $M$. brachyurus).

The Black-striped Wallaby ( $M$. dorsalis).

The Brush-tailed Kangaroo (Petrogale pencillata).

The kangaroos inhabit the continent of Australia, Tasmania, New Guinea, and other of the adjacent islands ; they, in common with nearly the whole mammalian fauna of the Australian region, belong to the order Marsupialia.

These animals derive their name (Greek, marsúpion-a purse) from a pouch or bag situated on the lower part of the abdomen in the female, and containing the teats. The young animal being born-so to speak-prematurely, is in an undeveloped condition, and is at once placed by the mother

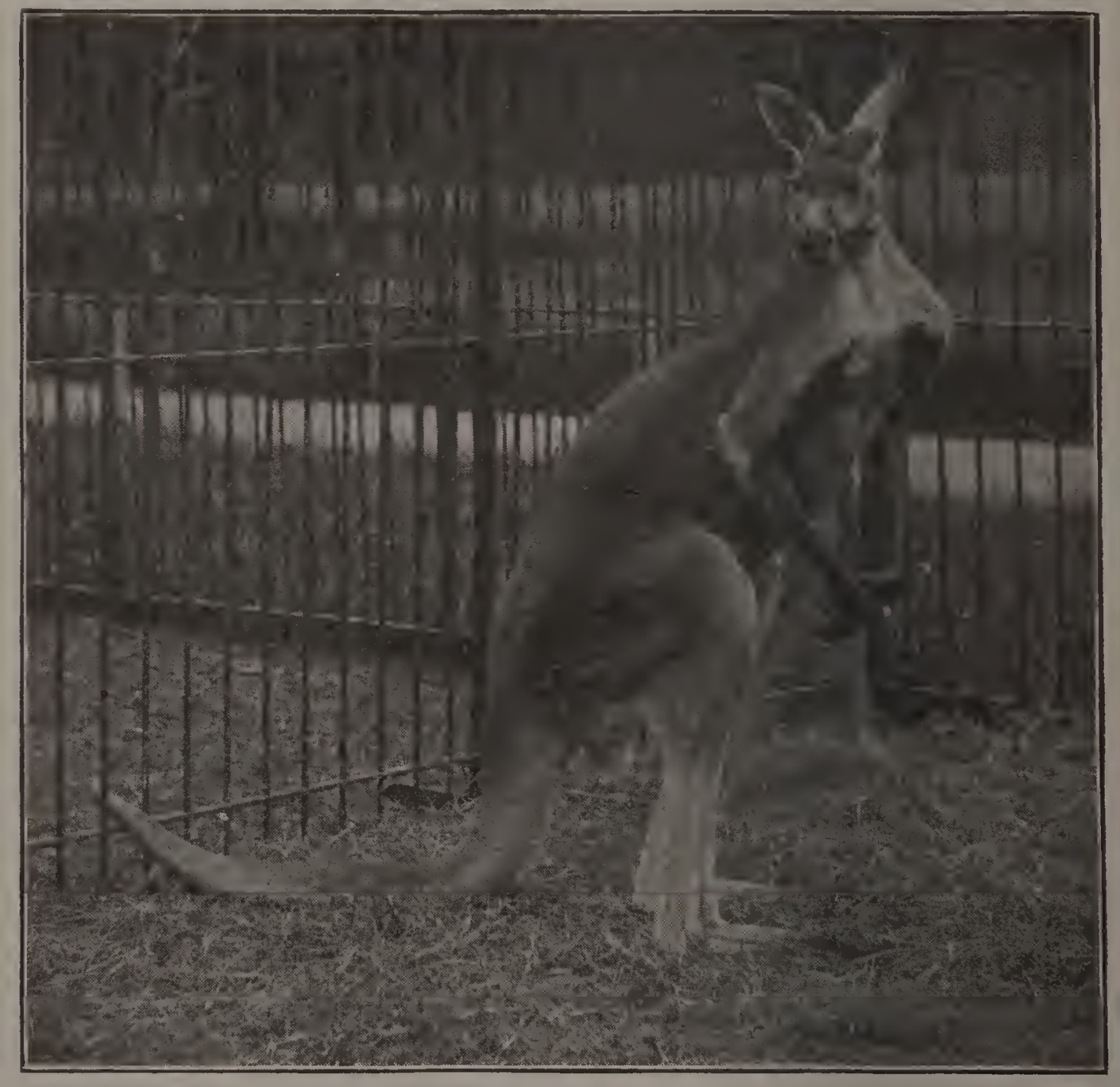

THE GREAT KANGAROO. 
in this pouch, where it attaches itself to a nipple and remains for some weeks until it has attained a weight of several pounds, when it gradually begins to come forth. It does not permanently leave the bag until it has grown so large as to be of an inconvenient size for the mother to carry about. The order is a large one, and outside of the Australian region contains only the opossums of America. It presents a striking variety of habits and adaptations of form among its members; many of the other mammalian orders being represented by marsupial forms, which agree, more or less perfectly, with them in habits.

The kangaroos fill a number of places in the economy of their native regions-there being brush kangaroos, rock kangaroos, and tree kangaroos, all of which are equally at home in the surroundings indicated by their respective names.

The wallabys are a sub-group of kangaroos, differing slightly in structure.

The Rufous Rat Kangaroo (Eprymmus rufescens) and Gaimard's Rat Kangaroo (Bettongia gaimardi) are small species from New South Wales.

All of the kangaroos are strictly herbivorous; most of them are hardy, breed readily, and might be acclimated in parks in the warmer temperate parts of the United States, with little difficulty.

Marsupials are probably near to the primitive ancestral mammals, fossil teeth having been found in the Jurassic formation, near Oxford, England, and also in the United States, the possessors of which without doubt belonged to this group, and in modern systems of classification they stand next to the lowest mammals; the Monotremata, consisting of two forms peculiar to Australia, being at the bottom. These strange animals, although of the mammalian class, possess certain structures of reptilian type, which affinity is even more strangely shown by the now established fact that they, alone among mammals, lay eggs which are hatched outside of the body of the parent, as in birds and many reptiles.

The society was fortunate enough in 1887 to secure a specimen of the Echidna, sometimes called the SpIny ANTEATER (Echidna hystrix), which lived for some months, an object of great interest to all classes of visitors. A second example has lived, at the present time, nearly a year in the Small Mammal House. 


\section{6}

There are several distinct forms of OsTRICH found in Africa. The one known as the Northern Ostrich (Struthio camelus) has the naked skin of the legs and neck of a bright pink flesh color. Another form from southern Africa (Struthio australis) has the same parts of a dull lead color, while the plates on the front of the lower leg and the gape of the bill are red.

They are natives of the hot, dry plains in the interior of Africa, over which they range in small flocks of rarely more than half a dozen, subsisting mainly on a species of melon which grows wild in those parts. The sexes are readily distinguished, the males, which furnish the choicest feathers, being black and white, while the females are gray. The ostrich is the largest known bird now existing, its head sometimes reaching to a height of eight feet above the ground. Its long legs give it great speed-some writers having estimated its pace, when first startled, at fifty miles an hour. Its feet, padded beneath like those of the camel, adapt it to coursing over the shifting, movable sands of its native regions without sinking.

The wings are reduced to mere rudiments, as in all the struthious birds, and are utterly useless for purposes of flight. It is said, however, that the ostrich spreads them and uses them as sails when-to use a nautical term-running before the wind.

Ostrich farming has been practiced in the Cape Colony for a long time, and within a few years has been introduced with some success into southern California and Florida.

The cassowaries are also kept in this building. There are some half dozen species of the genus Casuarius, mainly differing in the shape of the helmet on the head and the number and arrangement of the wattles hanging from the neck; all are natives of northern Australia, New Guinea, and a few neighboring islands. They belong to the order of struthious birds, with the ostrich, rhea, emu, and apteryx, all of which are characterized by great development of the lower limbs and loss of the power of flight.

The Common Cassowary (Casuarius galeatus) is from the island of Ceram, in the Indian Ocean, and BECCARI's CASSOWARY ( $C$. beccarii) inhabits New Guinea and the Aru Islands, while Casuarius australis, a fine species, is a native of Australia. The feathers of these birds are of a peculiarly filamentous or hair-like character, entirely wanting in the webs which spring 
from the sides of the shaft in ordinary feathers. They are birds of great power and endurance, rivaling even the ostrich in those qualities as well as in the famous powers of digestion which are so notorious in the latter bird.

Other members of the Struthiones are the RHEA (Rhea americana) from the plains of South America, and the EMU (Dromaus nove-hollandice) of Australia, the latter bird reaching nearly the proportions of the ostrich.

New Zealand contains the small flightless birds known as APTERYX or Kiwis. Small as they are, they are the last representatives of the gigantic MOA, once known in that island, but now extinct. Mantell's Kiwi (Apteryx mantelli) inhabits the north island; while the southern one is the home of Owen's KIwI (A.oweni). They are grotesque creatures, with disproportionately long bills, with which they bore into the mud after worms and insects, much in the manner of the woodcock. They are strictly nocturnal, and the visitor is rarely treated to a view. The accompanying plate is from a photograph taken in the Garden by flashlight.

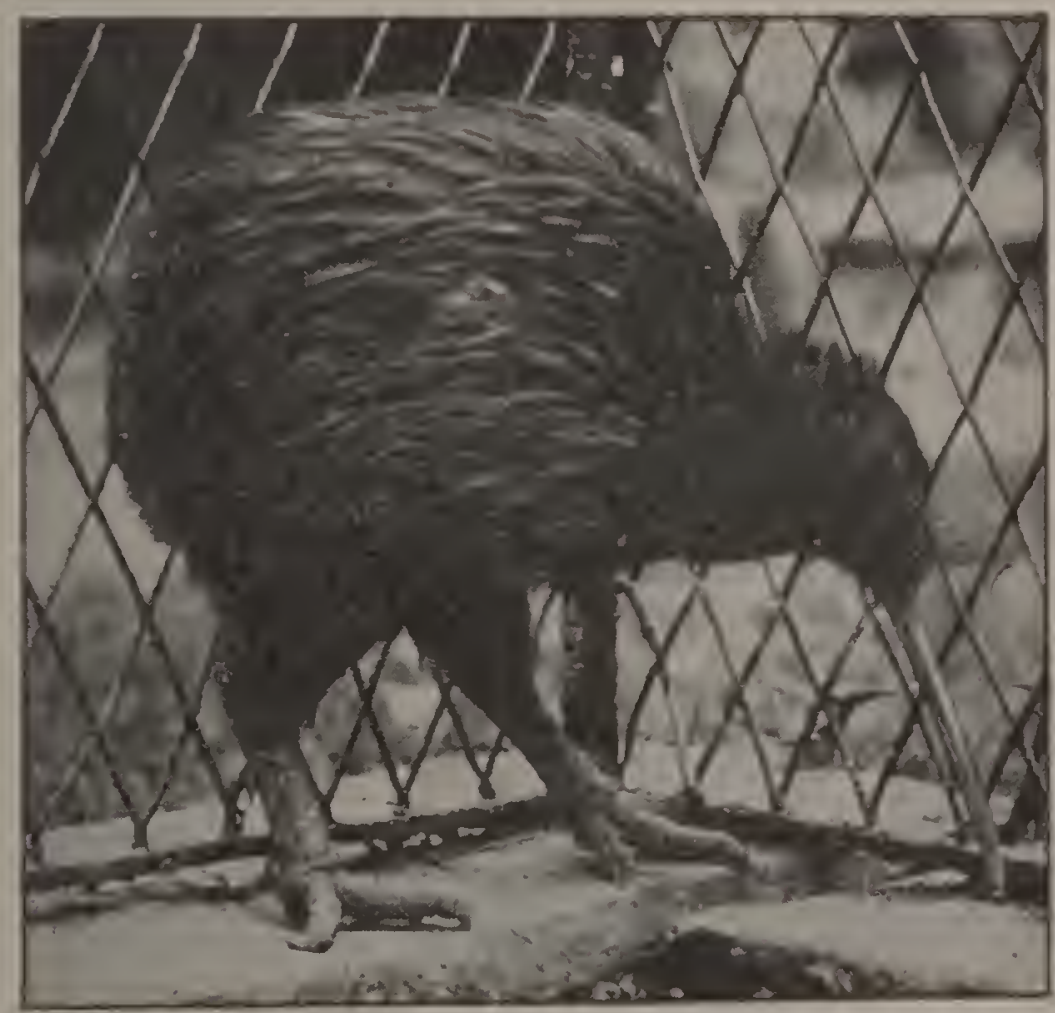

MANTELL'S APTERYX. 


\section{No. 24.-THE AVIARY.}

THIs building was constructed during the aummer and fall of $188 \mathrm{I}$, and was opened to the public in March of the following year. The north annex, containing the large series of parrots, was added in 1900 .

The order Passeres is the largest of all the higher groups, and includes more than one-half of the whole class of birds; all the songsters belong to it, and most of the birds familiar in our midst.

The thrushes are represented here by the WoOd THRush ( Iurdus mustelimus) of America, the RoBIN (T. migratorius), the English Blackbird ( $T$. merula), the Mocking Bird ( $T$. polyglottus), the CAT BIRD ( $G$. carolinensis), the Mocking Bird Thrush (Mimocichla rubripes), from Cuba, and a number of other species.

The Long-tailed Weaver Bird (Chera progne). This species may be known by the great elongation of the central tail-feathers of the male. These reach so great a length that a celebrated African traveler says of them:-

"I am informed that in the breeding season, when the male has assumed his nuptial livery and long tail-feathers, his flight is so labored that the children constantly run them down. They are quite unable to fly against the wind, and in rainy weather can hardly be got to move out of the thick bushes in which, knowing their helplessness, they conceal themselves.

"The Kaffir children stretch bird-limed lines across the fields of millet and Kaffir corn, and snare great numbers of the males by their tails becoming entangled in the lines.-Layard, "Birds of South Africa."

The weaver or whidah birds are noted for the peculiar nests which they weave from grass; these are mostly built on the community system, hundreds of the birds constructing together a sort of roof under which they separately build their nests. These nests are of different shapes, some of them much resembling a chemist's retort, with the neck down, the orifice serving as entrance for all the birds whose dwellings are within. They are all natives of Africa.

The birds of the genus Pyromelana are conspicuous by the livery of black and brilliant yellow or orange worn by the males during part of the year; the BISHOP WEAVER ( $P$. franciscana), and the Black-Bellied WeAver ( $P$. afer), being among them. 
The Larger Hill Mynah (Mainatus intermedius), the Com. mon Mynah (Acridotheres tristis), and the Brown Mynah ( $A$. fuscus) belong to an East Indian group, many of which learn to talk with much readiness.

More or less allied to these are the starlings of the old world and the blackbirds and troupials of the new. Conspicuous examples of these are the PURPLE GRACKLE or BLACKBIRD (Quiscalus quiscula), the RED-WINGED BLACKBIRD (Agelceus phaniceus), and the CowBIRd (Molothrus pecoris) of North America, the Baltimore Oriole (Icterus baltimore), the Yellow Troupial (Xanthosomus flavus), and others of the group from Central and South America, and the Comion European Starling (Sturnus vulgaris).

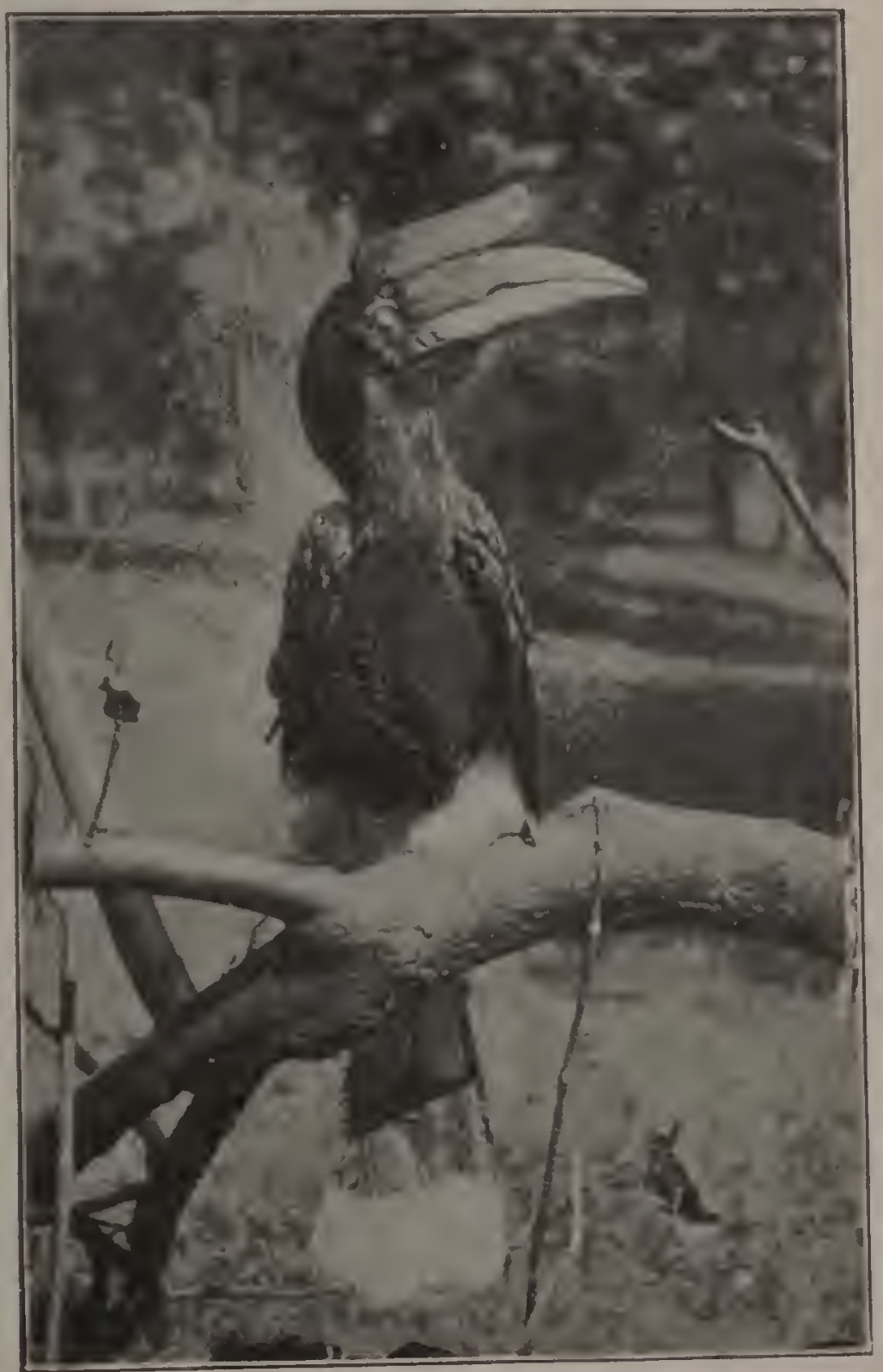

THE HORNBILL. 
The Reed Bird, Rice Bird, or Bobolink (Dolichonyx oryzivorus), is well known to epicures. They migrate in vast numbers from south to north at the approach of summer and back again towards autumn, at which time they become very fat on the ripened seed of the reeds which grow on marsh lands along the rivers near the coast, and are shot in great numbers as a table delicacy.

The Common Crow (Corvus americanus) and the RAven (C. carnivorus) are the leading American members of the family Corvida. The latter is now rarely found east of the Mississippi river, but is common in great numbers throughout the West. Others of the family are the European MagPie (Pica pica), JaCKDaW (Corvus monedula), and NUTCRACKER (Nucifraga caryocatactes) found in Europe; the White-backed PIPING CRow (Gymnorhina leuconota) and the Butcher CRow (Barita destructor), both of Australia, the Blue Jay (Cyanurus cristatus), of North America, the American Magpie (Pica pica hudsonica), closely resembling his European brother, the CHOUGH (Pyrrhocorax graculus), of Europe, the Pileated JAy (Cyanocorax pileata), a strikingly beautiful bird from southern Brazil, the PERUVIan JAY (Xanthoura ynca), the YUCATAN JAY (X. yucatanica) of Central America, the BLUE-BEARDED JAY (C. cyanopogon), and other species, commonly found in the collection.

The order Picarice is represented by the woodpeckers, kingfishers, cuckoos, toucans, hornbills, and trogons.

At the present time the Society is fortunate enough to exhibit a pair of CONCAVE-CASQued Hornbilis (Dichoceros bicornis), and a single specimen of the RHINOCEROS HORNBILL (Buceros rhinoceros), both natives of the Indo-Malayan region. These huge and grotesque birds are not often so well represented in collections.

The Giant Kingfisher or Laughing Jackass (Dacelo gigas) is the largest of the kingfishers, and inhabits Australia. It differs somewhat in habits from most of the immediate group to which it belongs, living in the woods, frequently far from water; its diet is also more mixed than is customary with its kind, as it eats not only fish, but small quadrupeds. birds, and reptiles. 


\section{1}

Its common name is derived from its cry, which has a striking resemblance to a hoarse laugh.

The common kingfisher of our country, which is often seen sitting motionless on a branch over the water, watching intently for a small fish to pass within its reach, is the BELTED KINGFISHER (Ceryle alcyon).

Quite a number of cuckoos are in existence throughout the world, some five or six being natives of America. THE Chaparral Cock (Geococcyx califormianus) of Texas and Arizona, also known as ROAD RUNNER, from the extraordinary speed with which it runs, the YeLLOw-BILled CUCKoo (Coccyzus americanus), and the Black-BILled Cuckoo ( $C$. erythopthalmus), belong to this family.

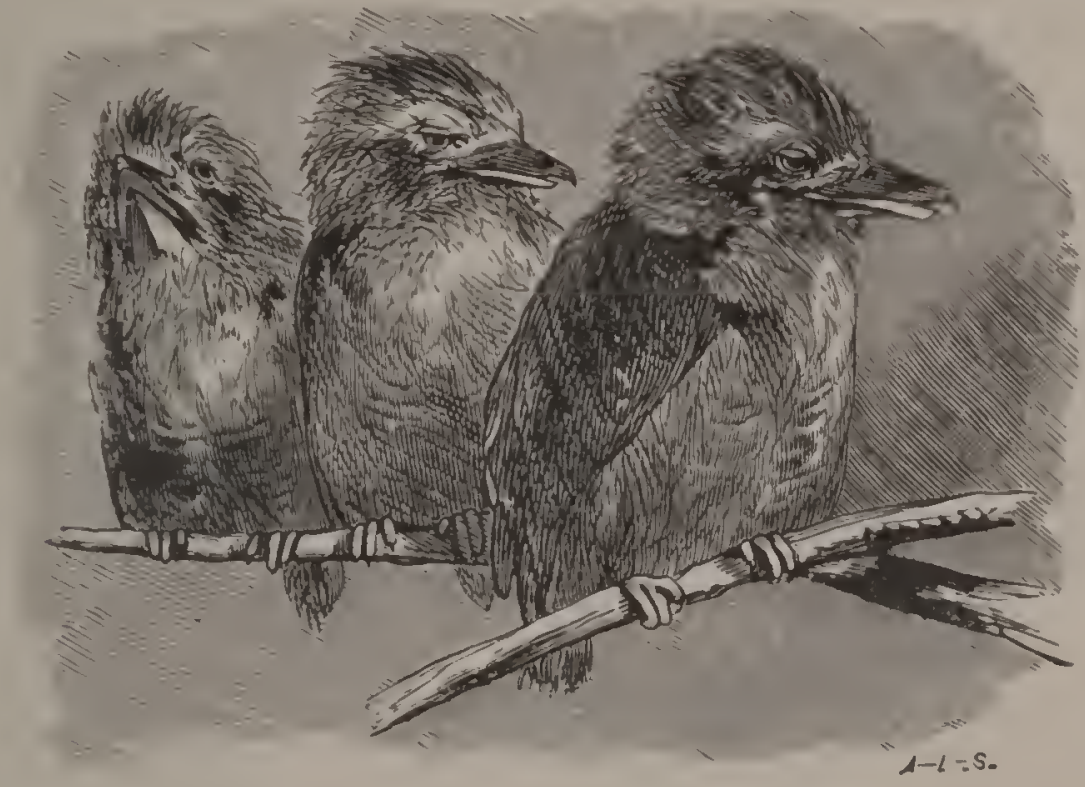

THE LAUGHING JACKASS.

The American cuckoos seem to be free from the strange habit of laying their eggs in the nests of other birds, a parasitical mode of providing for the young which is shared by a few unrelated species, as the AMERICAN COwBIRD, but which is more fully developed in the birds of this family, and notably in the Common Cuckoo (Cuculus canorum) of Europe.

The Toco Toucan (Rhamphastos toco).

Cuvier's Toucan ( $R$. cuvieri).

Ariel Toucan ( $R$. ariel).

The Sulphur-breasted Toucan ( $R$. carinatus).

The Green-billed Toucan ( $R$. dicolorus).

Maximilian's Aracari (Pteroglossus wiedi). 
The toucans are found only in tropical America, and will be readily recognized by the size and brilliant coloring of their bills,-large and unwieldy as these seem to be, they are in reality very light, being entirely filled with a honey-comb of air-cells. The plumage is richly colored, and has a peculiar satin-like softness of texture. The toucans are in a measure carnivorous, and often prey upon smaller birds.

"Common as these birds are in their native wilds, it is exceedingly difficult to detect their breeding-places; it is certain that they deposit their eggs in the hollow limbs and holes of the colossal trees so abundant in the tropical forests, but I was never so fortunate as to discover them. * * * In their manners, the Rhamphastida offer some resembiance to the Corvida and especially to the magpies; like them they are very troublesome to the birds of prey, particularly to the owls, which they surround and annoy by making a great noise, all the while jerking their tails upwards and downwards. "The flight of these hirds is easy and graceful, and they sweep with ease over the loftiest trees of their native forest." (Prince Maximilian of Wied.)

There are a number of species, beautifully illustrated by Mr. Gould, in a "Monograph of the Rhamphastidæ."

The Psittaci, comprising the macaws, parrots, parrakeets, and cockatoos, is a large and varied order, numbering some five hundred species, which are found throughout tropical America, Asia, Africa, and Australia. Among them are some of the most splendid specimens of their class; many of them learn to talk and imitate various sounds with facility, and they are much kept as pets.

Among the largest and most gorgeously colored of the group are the macaws. These superb birds live in large flocks in the forests of Central and South America, where their brilliant colors vie in intensity with the tropical vegetation which surrounds them.

There are a number of species, of which the best known are the Red and Blue MaCaw (Ara macao), the Red and Green MACAW ( $A$. chloroptera), the BluE and Yellow MACAW ( $A$. ararauna), Illiger's MACAW ( $A$. maracana), the BrownFronted MaCaw ( $A$. severa), the Military Macaw ( $A$. militaris), and the Glaucous MaCaw ( $A$. glauca).

A bird of rather strange appearance is the GREATER VASA PARRot (Coracopsis vasa) of Madagascar.

The Gray Parrot (Psittacus erythacus) and the Timneh Parrot ( $P$. timneh), from West Africa, furnish many of the best talkers of the family. 
The most beautiful, perhaps, of all these birds come from the Australian region, where are found a great number of species. Among them are Pennant's Parrakeet (Platycercus pennanti), the Rosehill Parrakeet ( $P$. eximius), the Paleheaded Parrakeet ( $P$. pallidice $p s$ ), Bauer's Parrakeet (P. zonarius), Barnard's ParRakeEt ( $P$. barnardi), SwainSON's LORIKEET (Tricoglossus nove-hollandice), the SCALYBREASTED LORIKEET ( $T$. chlorolepidotus), FORSTEN's LORIKeEt ( $T$. forsteni), the BlaCk-Talled Parrakeet (Polytelis melanurus), and the BloOD-RUmPed PARRAKEet (Psephotus hematonotus). The ZEBRA or GRASS PARRAKeET (Melopsittacus undulatus), also from Australia, is one of the most beautiful of these birds, -it is very small, and being of a green color, marked with undulating yellowish white lines, bordered with black, it is almost impossible to distinguish it from the grass in which it is generally to be found.

The Ring-necked Parrakeet (Palcormis torquatus), the Blossom-headed Parrakeet ( $P$. cyanocephala), the BlueSTREAKED LORY (Eos reticulata), the VIOLET-NECKED LORY (Eos riciniata), and the Alexandrine Parrakeet ( $P$. ale $x$ andri) are very handsome and graceful birds from India and the Asiatic Islands.

The parrots of the New IVorld, as a rule, are not so brilliantly colored as those from the other hemisphere, being generally green, with various markings of red, yellow, white, and blue.

Those kept as cage birds in this country commonly belong to the two large genera Chrysotis and Conurus; the former are known as Amazons and are birds of considerable size, with square tails of moderate length; the conures are smaller and have tails relatively longer and pointed.

Those which are usually in the collection are the YeLLowFRONTED AMAZON (Chrysotis ochrocephala), the YeLlowCHEEKED AMAZON ( $C$. autumnalis), the GOLDEN-NAPED Amazon ( $C$. auripalliata), the Blue-fronted Amazon ( $C$. versicolor), the WhITE-FRONTED AMAzON ( $C$. albifrons), the Yellow Conure (Comurus solstitialis), the Brown-ThroAted Conure ( $C$. aruginosus), the White-eared Conure ( $C$. leucotis), the Yellow-headed Conure ( $C$. jendaya), the CaCtus Conure ( $C$. cactorum), and Petz's Conure ( $C$. petzi). North America possesses one species, the Carolina Conure (C. carolinensis), which formerly ranged up to North Carolina and Kentucky, but which is now rarely found, even in the Gulf States. 
Two rare specimens are the SHORT-TAILED PARROT (Pionus brachyurus), from Brazil, and the VENEzUELA PARRAKEET (Bolborhynchus lineolatus).

A number of small parrakeets are common in South America, as the CAYENnE PARRAKEeT (Brotogerys tuipara), the Yellow-throated PARRAKEet ( $B$. tovi), the Orange-winged ParrakeEt ( $B$. xanthoptemis), the Yellow-Headed Parrakeet ( $B$. tui), and the Passerine Parrakeet (Psittacula passerina), the latter much resembling the love birds of Afriea.

The cockatoos are confined to the Australian region. Being for the most part large birds of graceful flight, their appearance in large flocks is described as being singularly beautiful. The following will be found in this building:The Slender-billed Cockatoo (Licmetis tenuirostris), Ducorps' Cockatoo (Cacatua ducorpsi), the Lesser Sulphur-Crested Cockatoo ( $C$. sulphurea), the SulPHUR-CRESTED Cockatoo ( $C$. galerita), the Roseate Cockatoo (C. roseicapilla), LEADBEATER's CockAtoo (C. leadbeateri), the ReD-vented Cockatoo ( $C$. phillipinarum), the Great White-crested Cockatoo ( $C$. cristata), and the Rose-CRESTEd CockAtoo ( $C$. moluccensis). These birds talk with ease and live to a great age,a specimen which recently died in the Garden was known to be at least ninety years old.

The Crested Grass Parrakeet (Calopsitta noncehollandice) is a very beautiful bird from Australia, living in hollow trees. Unlike most of its order, it breeds with some facility in confinement, when afforded proper accommodations.

The order Columber, comprising the pigeons and doves, is a very extensive group, containing over four hundred species, more than one-third of which are natives of the Malayan Archipelago, the remainder being distributed over the world. A number of species are indigenous to North America, many of which have been exhibited at the Garden; of these, the following are usually on hand:-

The White-crowned Pigeon (Columba leucocephala), southern United States and West Indies.

The Cuban Pigeon (C. inomata), West Indies. 
The Common Wild Pigeon (Ectopistes migratorius), North America.

The Blue-headed Pigeon (Starnanas cyanocephala, southern United States and West Indies.

The Carolina Dove (Zencedura carolinensis, ) North America.

The Zenaida Dove (Zenaida amabilis), West Indies.

The Key WeSt Dove (Geotrygon martinica), southern United States and West Indies.

The White-winged Dove (Melopeleia leucoptera), southwestern United States.

These birds are all more or less common in the regions where they are found. The common wild pigeon was migratory in habit, and formerly moved in enormous flocks of many millions. They used to be seen in some parts of the West, during their annual migration, covering acres of trees at night, when roosting, although it is now a question if they are not wholly extinct.

Many of the pigeons from the Malayan Islands, which is the great home of the order, are of striking beauty. Among them are the Blood-Breasted Pigeon (Phlogonas cruentata) of the Philippine Islands, the Bronze-winged Pigeon (Phaps chalcoptera) of Australia, the Green-winged Pigeon (Chalcophaps indica), the Australian PIGEON (Ocyphaps 10photes), the ReD-NAPEd Fruit Pigeon (Carpophaga paulina) of Celebes, the SPECKLed Dove (Turtur tigrina) of Burmah, the Eastern TUrtle Dove ( $T$. orientalis) from eastern Asia and the Goura or CRowned Pigeon (Goura coronata) of New Guinea. Another rare species, now to be seen here, is Sclater's Crowned Pigeon (G. sclateri).

The crowned pigeon is as large as a guinea-fowl, and has the top of its head surmounted by a beautiful crest of radiating feathers. The common species readily bears the winters of France and England, and has frequently bred there.

The Barbary Turtle Dove (Turtur risorius), the HalfCOLLARED Dove ( $T$. semi-torquatus) of Africa, the BARRED Dove (Geopelic striata), and the Ground Dove (Chamcepeleia passerina) of the southern United States and the West Indies belong also to this group.

The most aberrant member is the Tooth-BILLED PIGEON (Didunculus strigirostris), which derives its name from a number of serrations, like teeth, at the tip of the mandible, or lower bill. 


\section{6}

The species is of great rarity and comes from the Samoan Islands. A specimen formerly in the Garden was presented by the Smithsonian Institution.

A small group of birds known as Pterocletes is intermediate between the pigeons and the fowls, or gallinaceous birds. They are commonly called "sand-grouse" or "pigeon grouse." These birds are found only in southern Europe and the warmer portions of Africa and Asia. Their habits are in general similar to those of grouse and pheasants, and in India they are much sought by sportsmen.

The Black-Bellied Sand Grouse (Pterocles arenarius), ranging from Spain to India, is typical of the group.

The order Gallince includes the guinea, turkey, curassow, guan, pheasant, and partridge, and contains a large proportion of those birds which are known as "game birds," alike esteemed by the sportsman and the gourmand. They are mainly terrestrial birds. Some of them roost in trees, but during the day time live on the ground.

The curassows and guans belong exclusively to America, ranging from Mexico across the Isthmus of Panama down to the southern part of Brazil. They are large birds, living on fruits and seeds, and are said to be very well adapted for the table. They do not, however, breed with any facility in this latitude. Among them are-

The Crested Curassow (Crax alector), Guiana.

Daubenton's Curassow (C. daubentoni), Central America.

The Globose Curassow ( $C$. globicera), Central America.

Yarrell's Curassow ( $C$. carunculata), Brazil.

Sclater's Curassow ( $C$. sclateri), South America.

The Razor-billed Curassow (Mitua tuberosa), Brazil.

The Galeated Curassow (Pauxigaleata), South America. Greey's Guan (Penelope greeyi), New Granada.

The White-fronted Guan (P. jacucaca), Brazil.

The Red-breasted Guan ( $P$. pileata), Brazil.

The Red-vented Guan ( $P$. cristata), Central America.

White-eyebrowed GUAN ( $P$. superciliaris).

The Motmot Guan (Ortalis motmot), Guiana.

The Mexican Guan (O. vetula), Texas to Central America. 
The Jungle-fowl (Gallus bankiva), native to India, and without doubt the ancestor of the domestic fowl; the Guinea-Fowl (Numida meleagris), originally from Africa, but now domesticated all over the world; the VULTURINE Guinea-Fowl $(N$. vulturina), a rare and beautiful species from eastern Africa; the Common PEA Fowl (Pavo cristata), native to India, but, like the guinea, naturalized everywhere; and the Javan PEa Folvl ( $P$. muticus), from Java and the Malay Peninsula, distinguished from the foregoing by the peculiar shape of the plumes on the head, and by the rich green color on the breast-all belong to the Phasianida.

Sir Emerson Tennent states that the common pea fowl abounds to such an extent in the Island of Ceylon that its harsh cries at early morning are a great source of annoyance to the inhabitants. He also adds that the bird, as known in its domesticated state in other countries, gives but a very inadequate idea of its size and magnificence when seen in its native forests.

The Grouse are an allied group, generally distributed throughout the northern hemisphere. A number of them are natives of America, where they are commonly, though erroneously, called Pheasant and Partridge. They may always be distinguished from pheasants, a number of which have within a few years been domesticated in the United States, by the head, which in the grouse is always densely feathered, while in the pheasants there is usually more or less bare skin, often of a bright color. The tarsus, or lower leg, in the grouse is feathered down to the toes, this part in pheasants and quail being always more or less naked.

The Ruffed Grouse (Bonasa umbellus) and the Pinnated Grouse or Prairie Chicken (Cupidonia cupido) are two of the best known species.

The Common Partridge of Europe is Perdix perdix; other species often exhibited are the BARIBARY PARTRIDGE (Caccabis petrosa), the GREeK PARTRIDGE (C. saxatilis), and the Chukar PARTRIDGe ( $C$. chukar) of India; all of them are birds of some size, of pleasing plumage, and are clearly marked by their bright red legs. "The Common QuaIL ( $\mathrm{Co}$ turnix coturnix) of Europe and Asia is a bird of migratory habits and crosses the Mediterranean into Africa each au- 


\section{8}

tumn in countless numbers. Other species are found in Australia and New Zealand.

There are some forty species of American quail, differing slightly in structure of bill from the foregoing.

The well-known Common Partridge, Quall, or "BoBWHITE," as it is frequently called (Ortyx virginianus), is the most widely distributed species in North America, and has several marked varieties in the south-west and in CUBA. The female is lighter in color than the male, and has the buff of the neck replaced by white.

On the Pacific coast several genera have the head beautifully ornamented with plumes of feathers rising in various shapes. Examples of this form are the Plumed or Mountain Partridge (Oreortyx pictus), the Valley Quail (Lophortyx californicus), and GambeL's QUAIL ( $L$. gambeli), from Arizona and New Mexico.

Others are found in South America, as the WhITE-EARED QUAIL (Eupsychortyx leucotis).

The birds of the order Crypturi, containing the tinamous of South America, are of moderate size and offer a superficial likeness to some of the Gallince; their relationship, however, appears to be more nearly with struthious birds. There are some sixty known species, of which the Cinereous Tinamou (Tinamus cinereus), the LeAst Tinamou (Crypturus pileatus), which emits a peculiarly shrill and deafening cry, quite out of proportion to its size, and the Variegated Tinamou ( $C$. variegatus), are sometimes in the collection. Mr. Darwin, speaking of the tinamou in "The Zoology of the Voyage of the Beagle," states that it approximates somewhat to the habits of the grouse, but that it rarely rises from the ground, and may be readily caught with a stick having a noose at the end.

The order Steganopodes is composed of birds having all four toes fully connected by webs. They all have a more or less developed throat pouch; live upon fish, which they follow and catch in its native element, and are rarely found far from the sea-coast. Among the American representatives of the group which are usually to be found here, or in the creek behind the Deer Park, are the Common GanNET (Sula bassana) and the Booby Gannet ( $S$. fiber), found along the Atlantic coast, the latter rarely ranging as 
high as the Middle States, and the Common Cormorant (Graculus carbo), which ranges along the Atlantic coast from Labrador southward.

The strange-looking bird of this order, which is kept in the fountain basin in the Aviary, is the DARTER or WATER TURKey (Plotus anhinga). They are natives of the most impenetrable swamps of the Gulf States, and are so difficult of approach that their capture alive is an event of some rarity. They commonly perch on a branch closely overhanging the surface, and on the least alarm drop noiselessly into the water, and swim away unnoticed. Nuttall says of this bird :-

"Its long and dark serpentine neck and small head, vibrating backward and forward, present entirely the appearance of a snake, whether seen through the foliage of a tree, or emerging from the still and sluggish stream in which it often swims, with the body wholly immersed to the neck, and on being approached or startled, even that is instantly withdrawn, and sweeping beneath the flood in perfect silence, we at length see it again rise at a distance which defies approach."

There are three or four allied species in Asia, Africa, and Australia.

The Pelicans are well-known representatives of this group; of them, the Garden has the following:-

Brown Pelican (Pelecanus fuscus), North America.

IVhite Pelican ( $P$. trachyrhynchus), North America.

Crested Pelican ( $P$. crispus), Mediterranean Sea.

IVhite Pelican ( $P$. onocrotalus), Mediterranean Sea.

The last is a bird of remarkable beauty, the males being tinted with an exquisite rosy shade over the body when fully mature.

The American white pelican is peculiar in bearing near the middle of the upper side of the bill, an excrescence, which is shed at the close of the breeding season, about August, and grows out again in the following spring. The crested pelican, when adult, is the largest of these birds.

The Impennes, or wingless birds, are represented by the penguins, which inhabit the antarctic seas. In these birds the wings are so small as to be useless for flight, and serve the same purpose in swimming as the forelimbs of the seal. They dive and swim under water with marvelous rapidity in pursuit of the fish which is their chief food. But one speci- 
men of these interesting birds-the BLACK-FoOTED PENGUIN (Spheniscus demersus) - has as yet been obtained by the Society.

The orders Alectorides, containing cranes; Fulicarice, composed of the so-called "shore birds," snipe, plover, \&c.; and Rallida, the rails and gallinules, all contain more or less small species which require shelter. They live largely along water courses or on the seashore, from which they select the insects, worms, crustaceans, and seeds which serve them as food. Some of them are:-

The Cariama Crane (Cariama cristata), South America.

The Common Trumpeter (Psophia crepitans), Guiana.

The Green-winged Trumpeter ( $P$. viridis), Brazil.

The Cayenne Rail (Aramides cayennensis), South America and West Indies.

The Courlan (Aramus giganteus), Florida and West Indies.

The Carolina Rail (Porzana carolina), North America.

The Sickle-Billed Curlew (Numenius longirostris), North America.

The Clapper Rail (Rallus longirostris), eastern United States.

The King Rail ( $R$. elegans), eastern United States.

The Florida Gallinule (Gallinula galeata), Gulf States.

The Martinique Water Hen (Porphyrio martinica), southern United States and West Indies.

The Black-Backed Porphyrio ( $P$. melanotus), Australia.

The Hyacinthine Porphyrio ( $P$. hyacinthinus), Europe and Asia.

The Common Coot (Fulica americana), North America.

The American Woodcock (Philohela minor), eastern United States.

\section{No. 23.-THE SOUTHERN BIRD OF PREY CAGES.}

IT is the intention of the Society to erect a series of cages along the main walk below the Aviary for the collection of birds of prey. At present only four pairs of these enclosures have been completed, and the birds of this order are much scattered through the Garden. It is convenient, however, to enumerate them here. 
The Turkey Vulture (Cathartes aura), America.

The Black Vulture (C. atratus), southern United States.

The King Vulture (Gypagus papa), South America.

The Cinereous Vulture (Vultur cinereus), southern Europe and Africa.

The Pondichery Vulture ( $V$. calvus), India.

The, Griffon Vulture (Gyps fulvus), southern Europe and Africa.

The Lamaergeyer or Bearded Vulture (Gypoctos barbatus), Mediterranean region.

The Caracara Buzzard (Polyborus cherizuay), southern United States.

The Red-tailed Buzzard (Buteoborealis), North America. The Red-shouldered Buzzard ( $B$. lineatus), North America.

Swainson's Buzzard (B. swainsoni), western United States. The Rough-Legged Buzzard (Archibuteo lagopus sanctijohannis), North America.

The Osprey or Fish Hawk (Pandion haliaëtus), Whole world.

The Sparrow Hawk (Falco sparverius), North America.

The Prairie Falcon ( $F$. mexicamus), western United States.

The Kestrel (Tinnunculus alaudarius), Europe.

The MerLin (Hypotriorchis asalon), Europe.

The Pigeon Hawk (Accipter fuscus), North America.

The Tiny Hawk (A. tinus), West Indies.

Cooper's Hawk ( $A$. cooperi $)$, North America.

The Brahminy Kite (Haliastur intermedius), India.

The White Goshawk (Astur nova-hollandic), Australia.

The Greater Spotted Eagle (Aquila maculata), Europe and Asia.

The Lesser Spotted Eagle (A. pomarina), southern Russia.

Golden Eagle ( $A$. chrysatos), North America.

The Wedge.tailed Eagle $(A$. auda $x$ ), Australia.

The Bald Eagle (Haliaëtus leucocephalus), North America. The Cinerous Sea Eagle ( $H$. albicilla), northern Europe, Asia, and Greenland.

A large number of American species belong to the Accipitres.

The buzzards proper are a group of hawks, generally of large size and rather heavy flight. The eagles are closely 
associated with this division. The golden eagle and the bald eagle are occasionally seen in all parts of the country, though they are now somewhat rare along the Atlantic coast, and for a long distance into the interior. They are the only eagles properly belonging to the North American fauna, although as the bald eagle does not receive its white head and tail until its third year, its different stages of plumage have given rise to several vernacular names by which it is known.

Dr. Elliott Coues sums up the distribution and character of this species in his "Key to North American Birds" after the following descriptive manner :-

"North America, common; piscivorous; a piratical parasite of the Osprey; otherwise notorious as the Emblem of the Republic."

Certainly, on watching its filthy habits, its sneaking ways, and its thievish expression, one is not disposed to be proud of his "Bird of Freedom."

The falcons, harriers, kites, and goshawks are small hawks of rapid and vigorous flight and daring disposition. They are found all over the world. The falcons are readily distinguished by the presence of a notch-called the tooth-in the upper mandible.

The vultures are represented in North America by a family known as Cathartida, of which the best known species are the turkey vulture, common to all North America, and the black vulture, which is mainly confined to the south Atlantic and Gulf States, where they perform the duties of useful scavengers in the streets of even the large cities.

It may be mentioned here that the term "buzzard" is commonly, though improperly, applied to these birds; the true relation of the word has been given above.

The caracara belongs to a small group of hawks approaching somewhat in habit to the vultures. They range from South and Central America into the southern parts of the United States.

A strange bird, strictly belonging to the Accipitres, though bearing a resemblance in length of leg to the cranes and storks, is the Secretary Vulture (Serpentarius secretarius) of South Africa. Its name is derived from a tuft of feathers projecting backwards from each side of the head, and resembling the quill pen which clerks or secretaries frequently carry behind their ears. It is also known as "serpent-eater," from its habit of waging destructive war on the serpents which abound in its native country. It is a difficult bird to keep in 
captivity, its bones seeming to be very brittle-a slight blow or even a misstep being sometimes sufficient to break a leg.

THE CONDOR (Sarcorhamphus gryphus) is the largest of the vultures, rivaling and even exceeding in size the bearded vulture or I.ammergeyer of the Alps.

They do not build nests, but commonly live in pairs on the bare rock, high up among the lofty peaks of the Andes, from which they soar to a height almost beyond the range of human vision, plunging down only when their keen sight discovers the carcass of some dead animal on the plains below. They live mostly on carrion, but when pressed by hunger, it is said that several of them will sometimes band together, to attack a young calf or a disabled animal out of the herd, and with blows of their powerful beaks and claws destroy it. The sexes are very similar, but the female lacks the caruncles on the head and the wattles on the throat, possessed by the male.

The California Vulture (Pseudogryphus californianus) reaches almost the size of the condor. This species was formerly abundant on the western slope of the Sierra Nevada, in southern California, but has become almost extinct within a few years. They may be regarded as a great rarity in living collections.

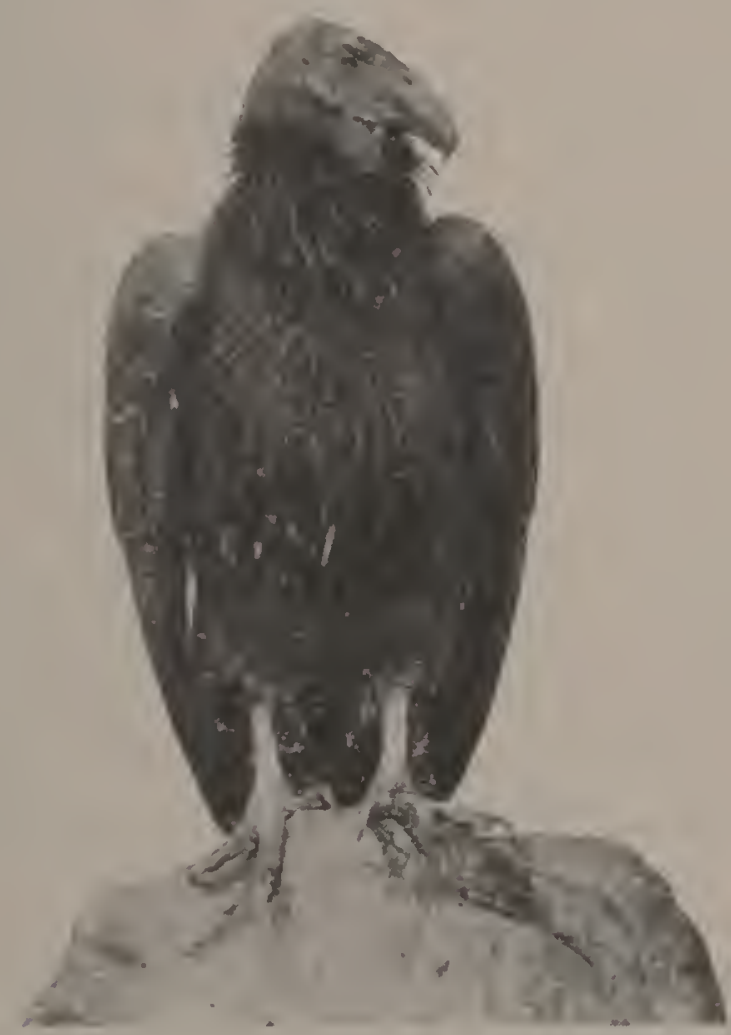

THE CALIFORNIA VULTURE. 


\section{No. 27.-THE POLAR BEAR PEN.}

This species (Ursus maritimus), is found throughout the arctic regions of Europe, Asia, and America, rarely ranging below the fifty-fifth degree of latitude; how far to the north they find their way is unknown. Sir Edward Parry saw them at latitude eighty-two.

They measure sometimes nine feet in length, and are dangerous visitors when pressed, as they often are, by hunger, to invade the camps of sailors, ice bound in the northern seas. They live on fish, seals, and blubber, and being perfectly at home in the water, pursue their prey and capture it in its native element. The following account is given by an arctic explorer of the cunning displayed by this animal in procuring food:-

"The Bear, on seeing his intended prey, gets quietly into the water and swims until to leeward of him, whence by short dives he silently makes his approach, and so arranges his distance that at the last dive he comes to the spot where the seal is lying. If the poor animal attempts to escape by rolling into the water, he falls into the bear's clutches; if, on the con. trary, he lies still, his destroyer makes a powerful spring, kills him on the ice, and devours him at leisure."

In captivity these animals live mostly on bread, with an occasional meal of fish.

On the right of the main walk leading up to the Lake, is the Southern Buffalo Pen, which was recently established for buffalo of a strain entirely distinct from those which have been for many years in the Garden. The main herd is described at page 74 .

\section{No. II.-THE LAKE.}

THE LAKE is occupied by a number of aquatic birds, belonging to the order Anseres. The following are usually to be seen :-

The Mute Swan (Cygnus olor), Europe.

The Black Swan (C. atratus), Australia.

The Whistling Swan (C. columbianus), North America. 
The Trumpeter Swan (C. buccinator), western North America.

The Black-necked Swan (C. nigricollis), South America. The Magpie Goose (Anseranas semipalmata), Australia.

The Egyptian Goose (Chenalopex agyptiaca), Africa.

The Blue Goose (Anser ccerulescens), North America.

The Snow Goose ( $A$. hyperboreus), North America.

The White-fronted Goose (A. albifrons gambeli), North America.

The Gray Goose $(A$. anser), northern Europe.

The Chinese Goose (A. cygnoides), China.

The Bar-Headed Goose ( $A$. indicus), India.

The Brant Goose (Branta bernicla), Europe and North America.

The Canada Goose (B. canadensis), North America.

The Bernicle Goose (B. leurcopsis), Europe.

The Maned Goose ( $B$. jubata), Australia.

The Common Sheldrake (Tadorna tadorna), Europe and Asia.

The Ruddy Sheldrake ( $T$. casarca), southern Europe, Asia, and Africa.

The Mallard (Anasboschas), North America, Europe, and Asia.

The Dusky or Black Duck (A. obscura), North America. The Pintall Duck (Dafila acuta), Europe and North America.

The American Widgeon (Mareca americana), North America.

The European Widgeon ( $M$. penelope), Europe.

The Canvas-backed Duck (Fulligula vallisneria), North America.

The Red-headed Duck ( $F$. ferina americana), North America.

The Little Black-headed Duck ( $F$. affinis), North America.

The Tufted Duck ( $F$. cristata), Europe.

The EIder Duck (Somateria mollissima), North Atlantic. 
Adjacent to the Lake, on the western side, is-

\section{No. 28.-THE STREAM FOR WATER FOWL,}

in which some of the ducks and geese enumerated above, which require special care and seclusion for their welfare, are kept.

The Summer or Wood Duck (Aix sponsa) of North America, the beautiful MANDARIN DUCK ( $A$. galericulata) of China, the Common Teal (Querquedula crecca), and the Garganey Teal (Q. circia), both of Europe, the Green-winged Teal (Q. carolinenisis) and BLUE-WINGED TEAL ( $Q$. discors) of our own country will be seen here.

The summer duck differs from all the other true ducks of this country in its habit of living in trees, -its nest being commonly made in a hollow limb at a considerable distance from the ground. A group known as Tree Ducks are found through the warmer parts of the earth. The WHITE-FACED TREe Duck (Dendrocygna viduata), the ReD-BILled TREe Duck ( $D$. autumnalis), the Black-Billed Tree DuCK ( $D$. arborea), and the INDIAN TREE DUCK (D. arcuata) are members of this group.

\section{No. 9. -THE PHEASANT ENCLOSURE.}

The true pheasants are indigenous to Asia and its islands; but the matchless beauty of their plumage, and the delicate quality of their flesh, have caused some of them to be largely introduced into Europe and the United States. The bird now known as the ENGLISH PhEasant (Phasianus colchicus) originally came from western Asia, and is believed to have been introduced into England about the close of the tenth century. It has long been perfectly naturalized, and is one of the most beautiful of the family. THE RiNG-NECKED Pheasant (Phasianus torquatus) has also long been domesticated in England, and has bred freely with the common pheasant; most of the birds known as ring-necked pheasants are the result of such a cross, in which the first-named bird seems to preponderate, the hybrids differing little in appearance from the original stock. Many of the pheasants have 


\section{7}

those feathers which lie immediately around the base of the tail-known as the upper tail coverts-immensely elongated, forming a large fan, like the train of the peacock, which they have the power to ercct at will, thus exposing a surface of brilliant and beautiful coloring, which in many species is without parallel in the animal kingdom. These plumes are developed to this extent only in the males, and from the fact of their being displayed frequently in the presence of the

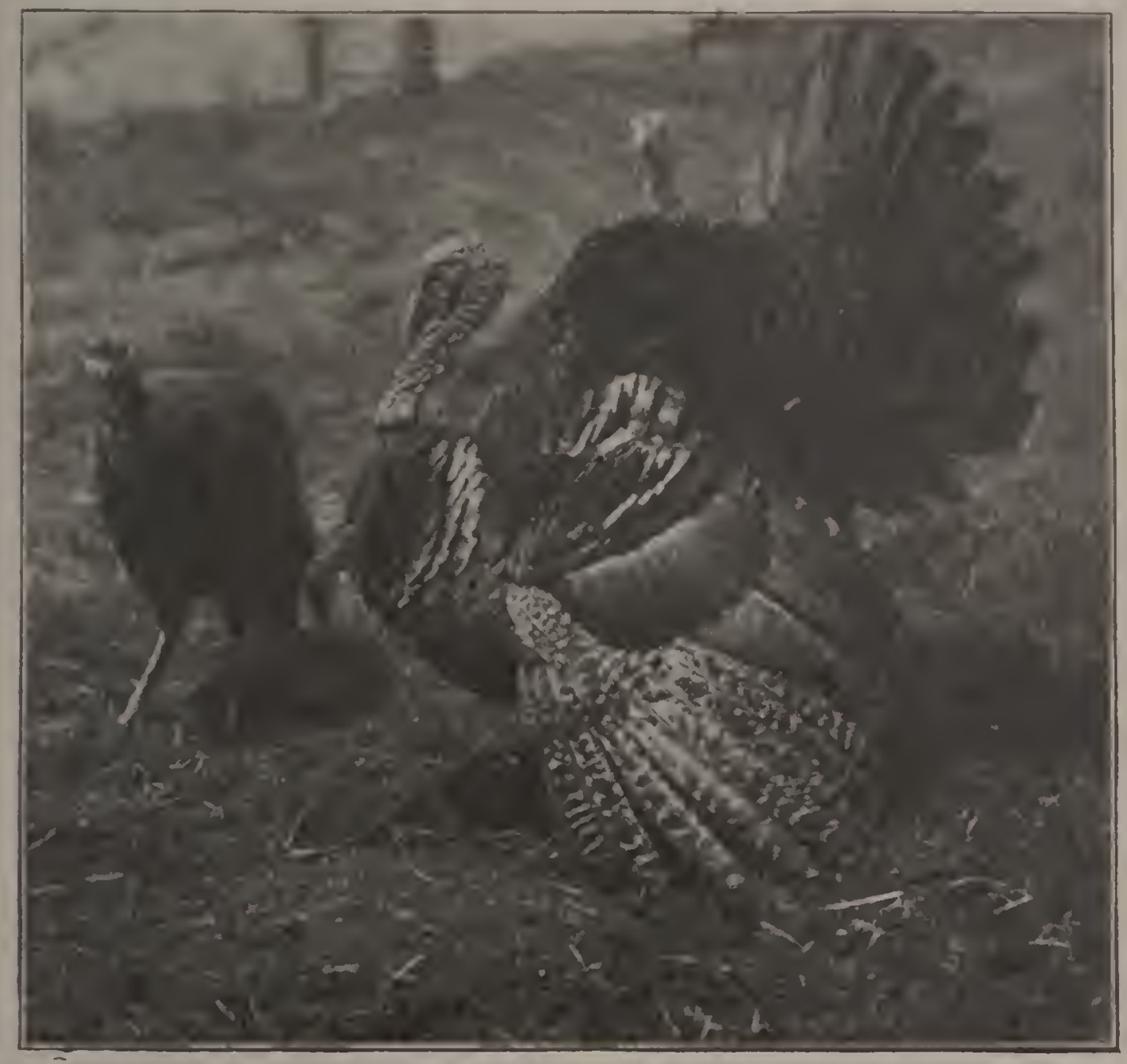

THE WILD TURKEY.

female during the breeding season, it is supposed that they play an important part in attracting her at this period.

One of the most beautiful of these birds is Reeves' PheasANT ( $P$. reevesi), in the male of which the tail sometimes reaches a length of six feet; of this, as well as the JAPANESE Pheasant ( $P$. versicolor), the collection contains specimens.

The Silver Pheasant (Euplocamus nycthemerus), the 
Golden Pheasant (Thaumalea picta), and Amherst's PheasANT ( $T$. amherstice) are natives of China, but have largely been acclimated elsewhere.

The magnificent Argus Pheasant (Argusianus argus) rivals the pea fowl in the display of feathers made by the male during the breeding season, and although the colors of the elongated feathers of the tail and wings are not brilliant as in the peacock, the quiet elegance of the pattern and shades borne by them constitute them an object of rare beauty. This species is found in Siam, Sumatra, and other parts of the Malayan region, but they are extremely delicate, rarely live long in captivity, and are not often seen in collections.

Specimens of the eastern WILD TURKEY (Meleagris gallopavo) are kept here. This splendid bird is now nearly extinct except in the wilder parts of the Alleghenies.

\section{No. 29.-THE LYNX CAGE.}

The Common American Lynx or Wild Cat (Lynx mufus) is distributed generally over the United States, and varies in color to so great an extent that some naturalists have insisted upon three or four not very well-defined species within the range of its distribution. Though in appearance it is ferocious to the last degree, it is in reality a cowardly beast, and subsists altogether upon small animals and birds.

In most localities it is known as the Catamount.

In the north it is replaced by the Canada LynX (L. canadensis), of somewhat larger size and grayer color. This species may also be known by the long tufts or pencils of hair which stand erect from the tip of the ear, and by its larger feet. As this lynx is found far to the north among the snows of British America, nature-fitting all things for their necessities-has developed the enormous paw which is characteristic of the species, to answer the part of a snow-shoe in enabling the animal to range at will and capture its prey on the surface of the snow, without sinking enough to be impeded in its progress.

A lynx closely similar is found in Europe and Asia, a fine specimen of which from Thibet, at present occupies this cage.

The European Wild Cat (Felis catus) is near at hand opposite the Monkey House, but as it rarely comes out during the day time, it is not often seen. 
These cats are among the most wild and shy of animals, and the publicity to which they are exposed in collections is probably the main reason why it seems impossible to keep them with success.

\section{No. I4.-THE DEER PARK.}

The Moose (Alces alces), called "elk" in Europe, often exceeds the largest horse in height; six and a half feet at the shoulder being no uncommon measurement. The antlers are widely palmated, or flattened, and spread sometimes six feet from tip to tip; specimens of enormous size are now being brought from Alaska.

The range of this magnificent animal is now very limited, but formerly included all suitable regions in northern Europe, Asia, and America. In this country they are now confined to Nova Scotia, New Brunswick, northern Ontario, Maine, Idaho, Wyoming, and Alaska.

During the season of rutting the bull moose is a savage and dangerous animal, and it is well to keep beyond the reach of the terrible blows which he deals with his sharp forehoofs. The animal is, however, susceptible of a considerable degree of domestication, the writer having recently seen one which had been broken to harness and trotted on the track. The gait of the animal is a long, swinging trot, and is very rapid.

Numerous attempts have been made in the Garden to keep specimens of the WOODLAND CARIBOU (Rangifer tarandus), but in all cases the unsuitable climate and the impossibility of providing the proper food have proved speedily fatal. The animal has an extremely northern range. There are two well-known species, the one referred to, reaching from Maine and New Brunswick westward to Lake Superior, and the BARREN LAND CARIBOU ( $R$. groenlandicus), far to the north in Greenland and Arctic America. A number of other species of doubtful standing have been described in recent years. They subsist for the most part on lichens, mosses, and small shoots and twigs of trees.

This is the only member of the deer family in which the female as well as the male has antlers. These are very irregular in development, and differ much in shape; the tip and also the brow antler are generally palmated to some extent.

The caribou is nearly related to the reindeer of Europe. 
The Virginia Deer (Mazama virginiana) is the common deer of the United States, and is found throughout North America; the so-called "white-tailed" deer of the west being indistinguishable from eastern specimens. They are easily tamed, and breed with tolerable readiness.

In Mexico they become much smaller, in accordance with a law general among North American herbivora, that the average size of a species becomes lessened towards the south. Several specimens of these small deer have been in the collection, and have bred freely with those from the east. A beautiful example of these is MEARns' DEER (Mazama texana), which ranges from southern Texas as far as Vera Cruz.

The Mule Deer ( $M$. macrotis) is found west of the Missouri river, where it is almost universally known as the "black tail," though wrongly so, as the true BLACK-TAILED Deer ( $M$. columbianus) is known only through a limited region to the north-west of the main mountain ranges. The former, intermediate in size between the common deer and the elk, but differing from both in form of antlers, is commonly found at present high up in the mountains, while the common species seem rather to affect lower pastures and heavily-timbered river bottoms. The range of either, however, depends much upon the available food supply and the season of the year.

The mule deer, like most herbivora from the far west, does not thrive when brought to this region, and much care is required to successfully raise the young.

The Hog Deer (Cervus porcinus) of India, derives its name from a somewhat porcine expression of countenance which is at once recognized. Close by, in an adjoining enclosure, is the JAPANESE DeER ( $C$. sika), a small and hardy species, which has but recently been introduced into the Garden.

The Fallow Deer ( $C$. dama) is the common deer of Europe. Its color is usually reddish-brown, spotted, like the axis, with white. It is liable to variation, however, some of those in the Garden being pure white.

The Roe (C. capreohus) is also found throughout Europe and in Asia, and though of small size, is one of the most graceful and beautiful of its kind. This little deer does not 
seem to endure captivity well, and the attempts which have been made by the Society to establish them here have not been successful.

The llamas, which are kept in this park, belong to the Camelide, and to a certain extent fill in South America the place which is held by the camels in Asia and Africa. They have long been domesticated, as Pizarro, on his conquest of Peru, found them in as general use as they are at the present time.

There are several wild species-the others, so far as is known, being descendants of the wild stock.

The Llana (Lama glama) is much used by the natives of Peru to transport burdens up the steep passes of the Andes, and is one of the domestic races.

Among the wild ones are the HuAnaco ( $L$. huanacos), about the size of the llama, but of a reddish-brown color, and the VICUNA ( $L$. vicugna), a smaller variety, covered with reddish-brown wool. These, like the AlpaCa ( $L$. pacos), are much hunted for the valuable wool which they yield. They are domesticated with ease, and the llama has bred several times in the Garden.

In the creek back of the Deer Park are usually a number of birds, some of which are placed in different buildings during the winter.

The Australian Crane, or Native Companion (Grus australasiana), Australia.

The IVhooping Crane ( $G$. americana), North America.

The Brown Crane (G. canadensis), North America.

The Sandhill Crane ( $G$. mexicamus), southern United States.

The Sarus Crane ( $G$. antigone), India.

The Cape Crowned Crane (Balaerica regulorum), South Africa.

The Crowned Crane (B. pavonina), IVest Africa.

The Demoiselle Crane (Anthropoizes virgo), Europe and North Africa.

ThE WoOd IBIS (Tantalus loculator), southern United States.

The White Ibis (Ibis alba), Gulf States. 


\section{2}

The Scarlet Ibis (I. rubra), South America.

The Common Bittern (Botaurus minor), North America.

The Tiger Bittern (Tigrosoma brasiliense), Brazil.

The Boat-Billed Heron (Cancroma cochlearia), South America.

The Night Heron (Nycticorax griseus navius), United States.

The Great White Egret (Arded egretta), southern United States.

The Great Blue Heron (A. herodias), North America.

The Little Blue Heron ( $A$. carulea), southern United States.

The Least Bittern ( $A$. exilis), United States.

The Australian Sacred Ibis (Ibis strictipennis), which is closely similar to the African bird formerly venerated by the Egyptians.

These all belong to two somewhat closely related orders, Alectorides and Herodiones. In them the legs are usually of great length, and are commonly bare of feathers for some distance above the tarsal joint ; the neck is, in most species, of length proportioned to the legs. There are numerous forms distributed all over the world.

The Adjutan'r (Leptoptilus argala) of India is one of the extensive family of storks, which are found throughout the world, with the exception of North America ; it will be easily recognized by its long, thick bill. In its native country it wages successful war upon the many venomous reptiles which there find a home, and also perfornis a part similar to that which is effectively taken in our Southern States by the black vulture. This is well stated in Jerdon's "Birds of India " :-

"In Calcutta and some other large towns, the Adjutant is a familiar bird, unscared by the near approach of man or dog, and protected, in some cases, by law. It is an efficient scavenger, attending the neighborhood of slaughter-houses, and especially the burning-grounds of the Hindoos, when the often half-burnt carcasses are thrown into the river. It also diligently looks over the heaps of refuse and offal thrown out into the streets to await the arrival of the scavenger's cart, where it may be seen in company with dogs, kites, and crows. It likes to vary its food, however, and may often be seen searching ditches, pools of water, and tanks for frogs and fish. In the Deccan it soars to an immense height in the air along with vultures, ready to descend on any carcass that may be discovered." 
A smaller species, otherwise much like the preceding, is the Javan Adjutant (L. javanicus); another, called Marabou (L. crumeniferus), inhabits Africa.

The IVhite Stork (Ciconia alba) is a well-known summer resident in central Europe, particularly in Holland and Germany, retiring into Asia and Africa at the approach of winter. It is almost a household bird, living even in the midst of large cities, and in parts of Germany is regarded with superstitious reverence. With it, in the Garden, is associated the BI,ACK STORK ( $C$. nigra), from the same localities.

A rare species from west Africa, the SAdDLE-BILled Stork (Xenorhynchus senegalensis), is also to be seen in the collection.

The flamingoes, forming the order Odontoglossa, seem to be related on the one side to storks, and on the other to Anseres. There are some half dozen species, all resident in tropical regions; all are pink or red in color, though they soon fade in captivity, and all have the bill curiously bent downwards in the middle. The common American species is Phanicopterus ruber, which inhabits Florida, the West Indies, and northern South America. These birds do not live long in captivity, and one can never be sure of finding them in the collection.

The Fulmar Petrel (Fulmaris glacialis), the Parasitic JAEGER Gull (Stercorarius parasiticus), the LAUGHING GULL (Larus atricilla), and the GREAT BLACK-BACKED GuLL ( $L$. marinus) are nembers of the order Gavia, and are found along the coast of the Atlantic States; the first two have a very extensive range to the north.

The large Alligator (Alligator mississippiensis) is generally to be seen during warm weather in the compartment at the lower end of this creek, either sunning himself on the bank or submerged in the water, nothing being visible but the tips of the ridges over the eye and the protuberance around the nostrils on the extreme end of the snout. This species is found in the rivers and bayous of the Gulf States, and is allied to the crocodile and gavial of Egypt and southern Asia, and the caiman and jacare of South America. One species of CrocoDILE (Crocodilus americanus) is also found in South America and Cuba, and quite rarely among the keys which border the southern coast of Florida. 


\section{No. I8.-THE OTTER POND.}

The American Otter (Lutra canadensis) has a general range throughout North America, though to a less extent and in fewer numbers than formerly, owing to the great demand for the beautiful fur obtained from them. Like their relative, the Brown Mink (Putorius vison), they are largely. aquatic in habit and live chiefly upon fish, which they catch with ease and devour in incalculable numbers. They are lively, sportive animals, and the visitor will find much amusement in watching their gambols in the pond set apart for them.

In a wild state they have a curious means of diversion, which is thus described by Godman :-

"Their favorite sport is sliding, and for this purpose in winter the highest ridge of snow is selected, to the top of which the Otters scramble, where, lying on the belly with the fore-feet hent backwards, they give themselves an impulse with the hind legs and swiftly glide headforemost down the declivity, sometimes for the distance of twenty yards. This sport they continue apparently with the keenest enjoyment, until fatigue or hunger induces them to desist."

Otter are not easy to capture uninjured, and it is with difficulty that a sufficient number is obtained for the collection. The European species (Lutra lutra), is closely similar to our own.

\section{No. I6.-THE BUFFALO PENS.}

The American Bison or Buffalo (Bison bison). The Society possesses one of the finest herds of these animals now remaining.

Of the geographical distribution of this species, past and present, Prof. J. A. Allen treats as follows in a "History of the American Bison," published by the Department of the Interior in $1877:-$

"The habitat of the Bison formerly extended from Great Slave Lake, on the nurth, in latitude about $62^{\circ}$, to the north-eastern provinces of Mexico, as far south as latitude $25^{\circ}$. Its range in British North America extended from the Rocky mountains on the west to the wooded highlands about six hundred miles west of Hudson's Bay, or about to a line running south-eastward from the Great Slave Lake to the Lake of the Woods. Its range in the United States formerly embraced a considerable area west of 
the Rocky mountains-its recent remains having been found in Oregon as far west as the Blue mountains, and further south it occupied the Great Slave Lake basin, extending westward even to the Sierra Nevada mountains, while less than fifty years since it existed over the headwaters of the Green and Grand rivers, and other sources of the Colorado. East of the Rocky mountains its range extended southward far beyond the Rio Grande, and eastward through the region drained by the Ohio and its tributaries. Its northern limit, east of the Mississippi, was the great lakes, along which it extended to near the eastern end of Lake Erie. It appears not to have occurred south of the Tennessee river, and only to a limited extent east of the Alleghenies, chiefly in the upper districts of North and South Carolina.

"Its present range embraces two distinct and comparatively small areas. The southern is chiefly limited to western Kansas, a part of the Indian Territory, and north-western Texas-in all together embracing a region about equal in size to the present State of Kansas. The northern district extends from the sources of the principal southern tributaries of the Yellowstone northward into the British possessions, embracing an area not much greater than the present territory of Montana. Over these regions, however, it is rapidly disappearing, and at its present rate of decrease will certainly become wholly extinct within the next quarter of a century."

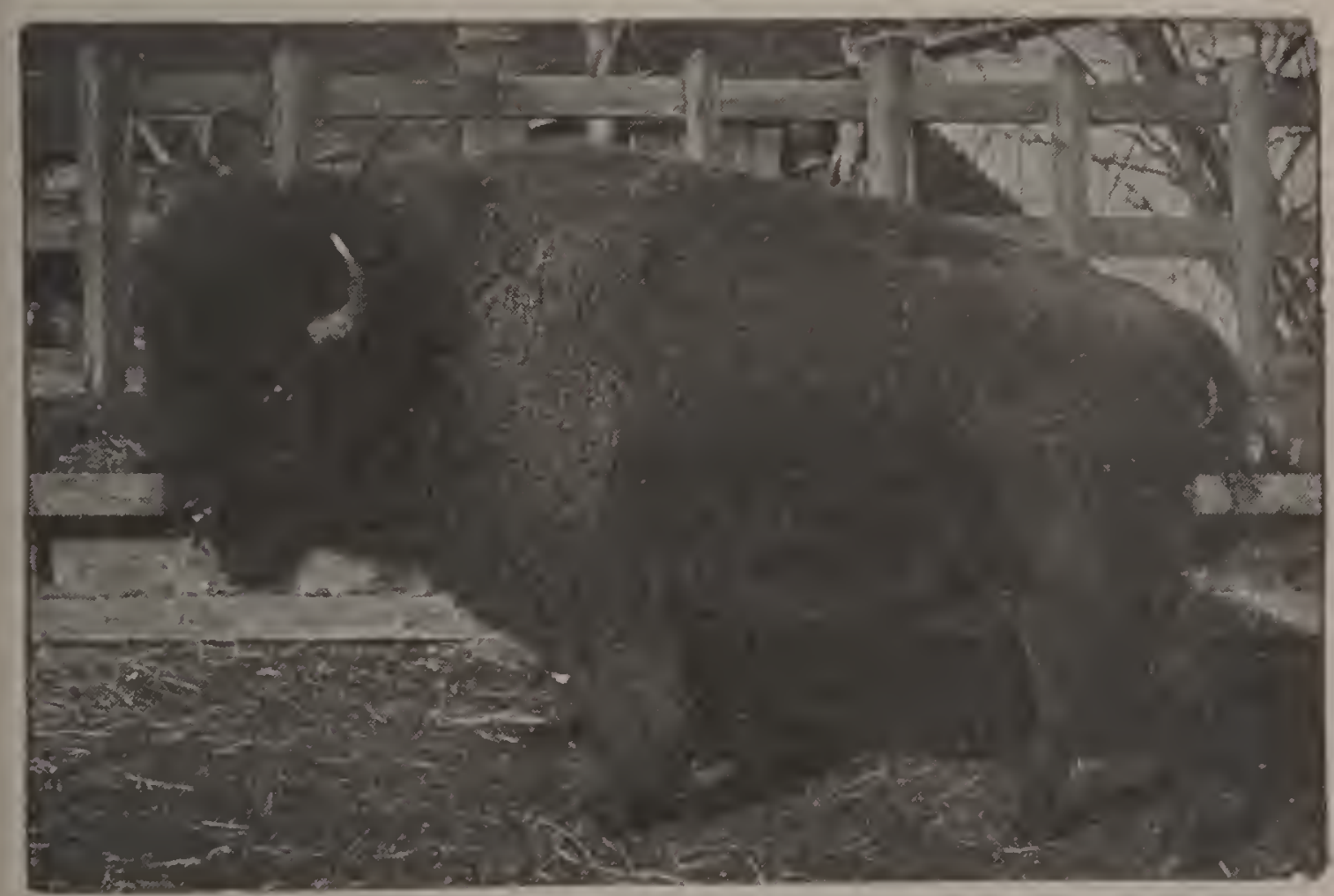

THE BISON.

Over nearly the whole of this country the bison formerly ranged in vast herds, and the destructive side of man's nature cannot be better realized than in contemplating the details of its extinction. It has been estimated by careful and 
competent authorities, that from the year I870 to I 875 they were killed at the rate of two and one-half million a year.

The due result of this prodigious and unchecked slaughter has already been reached, as it is now possible to say that the bison no longer exists within the United States outside of preserves, such as the Yellowstone National Park and private enclosures. A small herd is said to range far up in British America in the region of the Peace river.

\section{No. 17.-THE FOX AND WOLF PENS.}

The Red Fox (Canis vulpes pennsylvanicus) ranges in large numbers from the Carolinas northward into Canada, and from the Atlantic coast to the west. It is subject to much variation-the CRoss Fox, a beautiful animal marked with two black stripes crossing each other on the shoulders, and the Silver Fox, found sparingly in the northwestern Statesboth being well-marked varieties. The latter is known by the beautiful and expensive furs which it supplies.

The Gray Fox (C. cinereo-argentatus) has a complete range throughout the United States, increasing in numbers towards the south, where it gradually replaces the red fox, which it much resembles in mode of life. This species alone, among the dog tribe, has the habit of climbing trees when closely pursued.

With the single exception of the little CoAst Fox ( $C$. littoralis), from lower California and Central America, the Kit or Swift Fox (C. velox) is the smallest of American foxes, and is confined to the plains of the west.

The Arctic Fox (C. lagopus) is common to the polar regions of the north, in both hemispheres. Like many species which inhabit countries where the ground is covered with snow for a large part of the year, the fur of the arctic fox changes from a lead-blue color to white at the approach of winter. This provision of nature causes it to be less conspicuous against the snow and ice which surround it, and greatly aids it in pursuing its prey.

The Great Gray or Timber Wolf, called Lobo by the Mexicans (Canis lupus mexicanus), is the largest of American 


\section{7}

wolves, and formerly ranged over the whole United States and Canada. The settlement of the country has, however, driven them, with other noxious beasts, to the more secluded forests and plains, where they are beyond the reach of man. The common color of the species is grayish-white, but it varies all the way from pure white to deep black.

The Common Wolf (C. lupus) of Europe resembles the gray wolf.

The Prairie IVolf or Cayote (C. latrans) is well known to all western travelers. Beyond the Missouri river they range in packs of from five or six to twenty, from Mexico well up into British America. They are intermediate in size between the fox and gray wolf, and live mostly on the carcasses which are found upon the plains.

Melanistic specimens of this animal, and also of the timber wolf, several of which are almost entirely black, are in the collection.

The Jackal plays in Africa the part taken in America by the cayote. The NorTH African JACKal (Canis anthus), the Black-Backed ( $C$. mesomelas), and the Indian Jackal ( $C$. aureus), are frequently exhibited.

South America possesses several species of small wolves, very fox-like in some of their characters. By some naturalists they have been constituted a group in termediate between the two. Azara's Fox ( $C$. azara) and the Crab-eating Fox ( $C$. cancrivorus) belong to this group.

It is an open question whether the DiNGo, or WILD DoG (C. dingo), of Australia is an aboriginally wild stock, or is descended from introduced progenitors which ran wild. In any case their fossil remains are found in Pleistocene strata. They are cowardly brutes, susceptible of little domestication, and cause by their depredations much loss to the sheepraisers of Australia.

A curious little dog, whose external appearance is indicated by its name, is the RACCOON-LIKE DOG (Canis procyonoides), of north-eastern Asia.

The dogs, wolves, and foxes, with the jackals, constitute a family of Carnivora known as the Canide. 


\section{No. I9.-THE CATTLE PENS.}

Opposite the wolves is an iron enclosure divided into pens in which are generally kept various oxen, sheep, and goats; although at times the necessities of the Garden require that other animals should be placed here as well.

This group of even-toed ungulates, which, with the antelopes, is known as the Bovidae, is well marked by the character of their horns, which consist of an outside sheath, composed of the same tissue which forms hair and nails; this sheath is attached to a bony core projecting from the frontal bone, and is never shed, like the antlers of deer, but if knocked off by accident it does not grow again. Sheep and goats are so closely related that it is not easy to characterize the difference. They usually live in mountainous regions, while oxen and antelope prefer plains, or at least moderate elevations.

The Indian Buffalo (Bubelus buffelus) has been domesticated for ages in its native country, but is also found there in a wild state. The wild ones, called Arna, are fond of the impenetrable, swampy jungles, common in southern Asia. The Bhainsa, or tame race, are largely used as working oxen, not only in their own country, but in southern Europe-the buffalo found on the Campagna, near Rome, being of this breed, as also are the Carabao, used as beasts of burden in the Philippine Islands.

The Anoa or Celebes Buffalo (Bos depressicornis), is a dwarfed representative of the Indian species, and rarely measures much over three feet in height at the shoulder. The male now in the Garden is kept in one of these pens through the summer; in winter being placed in the Antelope House.

The ZEBu (Bos indicus). A number of breeds of these cattle exist throughout China, India, and north Africa, varying in size from that of a calf to the full adult of our ordinary domestic cattle. They differ much in appearance, there being breeds without horns, and some almost without the characteristic hump on the shoulders, while in others the horns are of great size, and some in which the hump weighs from forty to fifty pounds. 
They are much used as beasts of burden, and are also saddled and ridden. They can be acclimated in this country with a little care and breed readily, but have not been found to be of much economic value in comparison with the established breeds of our own cattle. The sacred cattle of the Hindoos are of this stock.

THE YAK (Pö̈phagus grunniens), in a wild state is native to

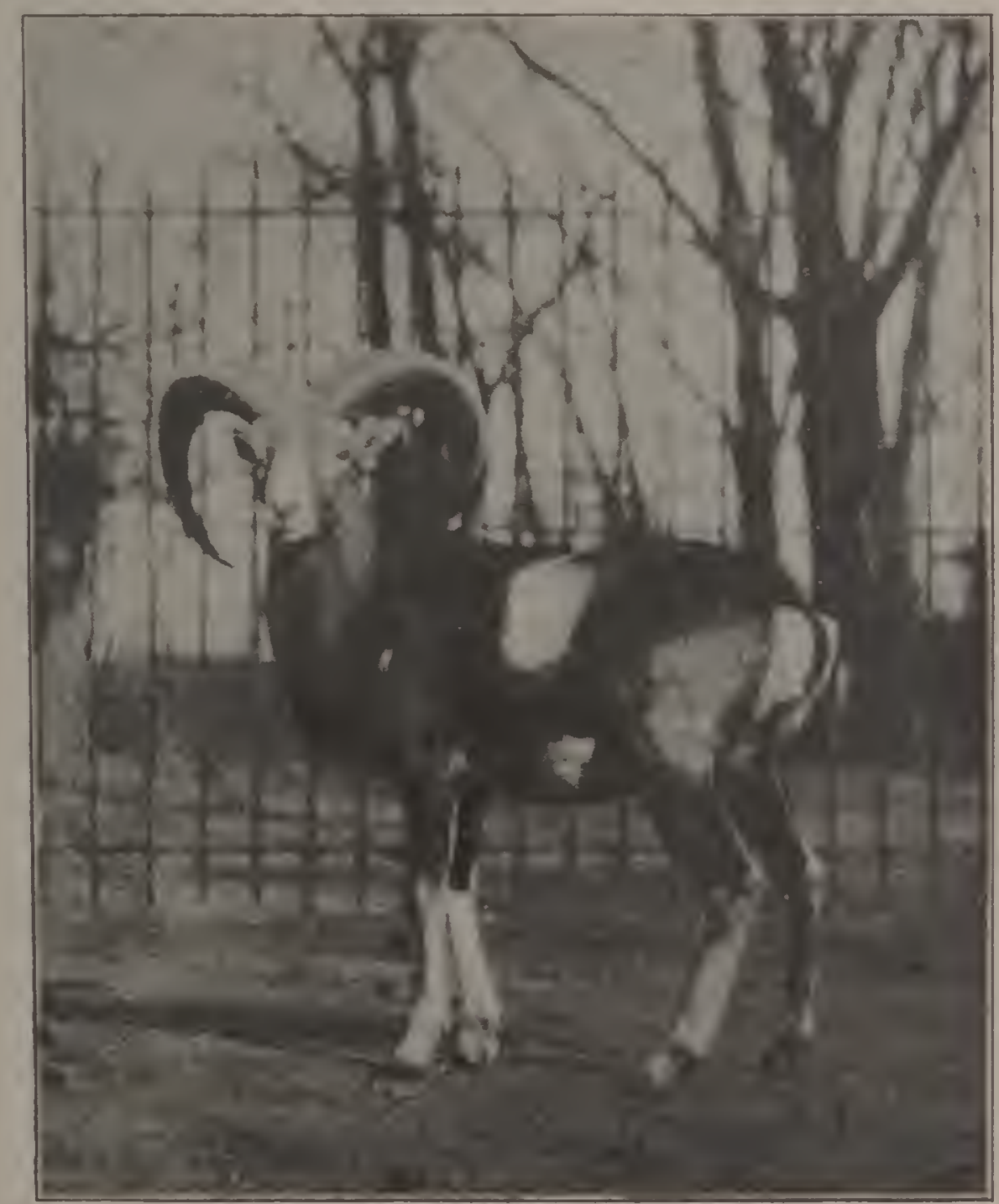

THE MOUFLON.

the high mountain ranges and plateaus of Thibet and Tartary. There are several domestic breeds used all over central Asia for purposes of draught and burden. The long hair is much used in the manufacture of various fabrics, and the tails are much prized by the Tartars and Chinese, constituting among the former an insignia of rank when attached to the head of a 
lance; by the Chinese they are dyed of various colors and used as fly-flappers.

The wild yak is a somewhat sullen and ill-tempered brute, and can use its long horns sideways with great effect.

The Domestic Sheep (Ovis aries), like the goat in its domesticated forms, is an inhabitant of the whole world.

The Rucky Mountain Sheep (Ovis canadensis) was a former frequenter of the whole chain of the Rocky mountain system, and those of the Pacific coast from Alaska to the Peninsula of lower California and western Texas. He was even found in outlying spurs and ranges in Wyoming and Montana, and in the Bad Lands along the Little Missouri river in Dakota, but through all this vast region he has become scarce, except, perhaps, in Alaska, where it is represented by a distinct species. The few survivors have become wild and shy, ranging high up in rough mountains, where they are difficult of approach. They have never been domesticated with success, and few of them have been shown in captivity.

Another fine species is the Punjab Wild Sheep (Ovis vignei), from the Himalayas of India.

The AOUdad (Ovis tragelaphus) comes from the mountains of north Africa, and resembles the mountain sheep, but has a thick beard hanging from the throat to below the knees. Another sheep frequently shown in collections is the MoufLoN (O. musimon) from Corsica and Sardinia.

The wild goats inhabit the roughest mountain ranges of southern Europe and Asia, from Spain to India; many species have long and powerful horns, much valued as trophies, and the qualities of nerve, hardihood, and marksmanship necessary to hunt them with success have for centuries rendered them favorite objects of the chase. The Swiss Ibex (Capra ibex) has long been extinct except in the preserve established in the Piedmontese Alps by the late King Victor Emanuel of Italy; the ibex procured for exhibition in these days generally belong to the Spanish species (C. pyreniaca).

Another species, which was formerly common throughout the Grecian Archipelago, now seems to be restricted to Crete and other of the smaller Cyclades, as well as south-western Asia. This goat (C. agagrus) was frequently referred to by 
Homer, and is probably the ancestor of the domestic animal, and it is by no means certain that the specimens now found in the islands referred to are not the progeny of the common form, run wild, as seems to be the case with the goats from the island of Ioura, to which the name of Capra dorcas has been given.

Several examples of the CHamors (Rupicapra tragus) have been shown in the Gardens. This goat-antelope, as it may

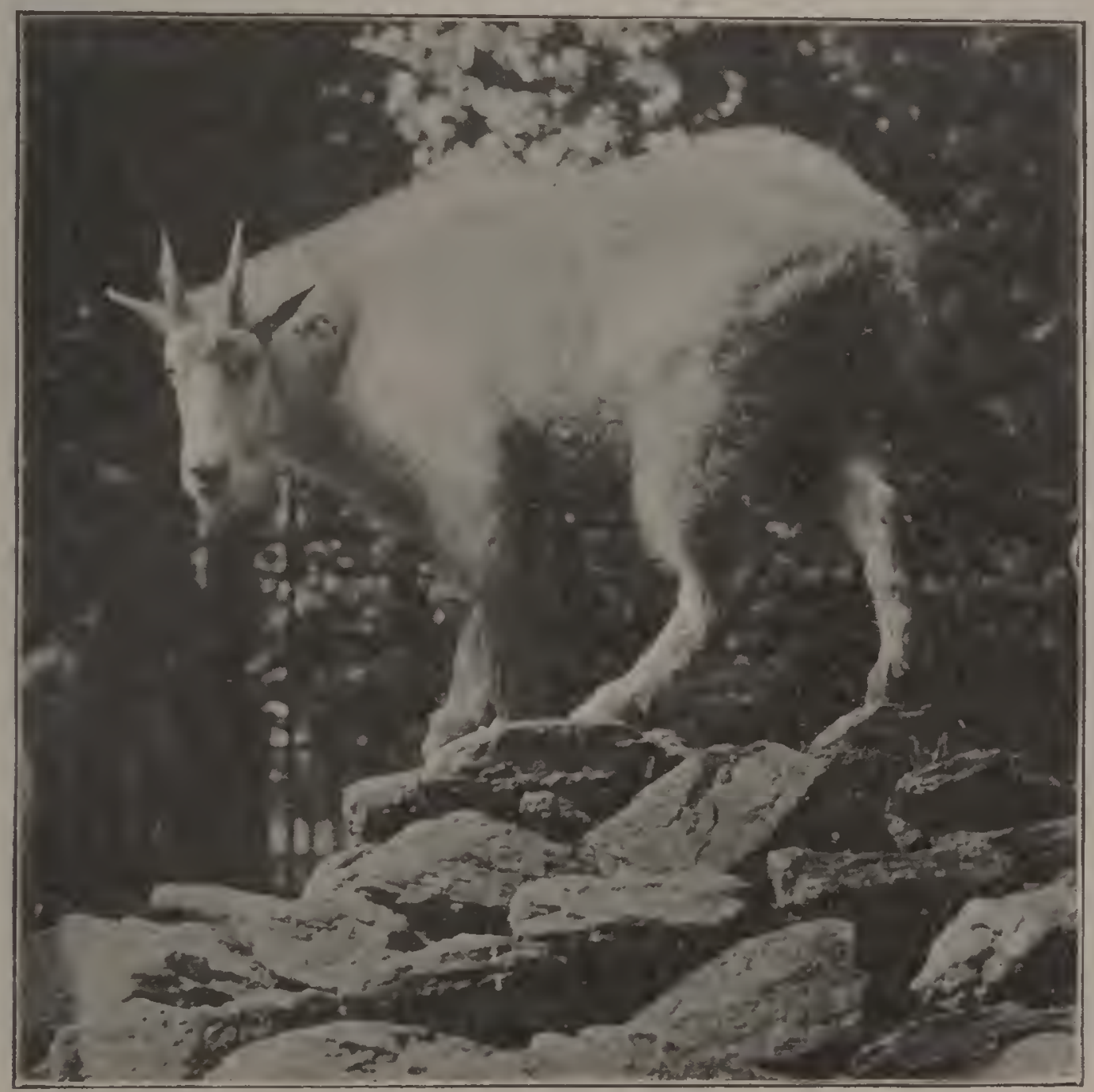

THE MOUNTAIN GOAT.

Le termed, inhabits the elevated parts of the Pyrenees and of the Alps. They are carefully protected on the vast hunting preserves in Switzerland and the Tyrol, on which large numbers are killed each year during the proper season.

The so-called White, or Mountain Goat (Oreamnos montamus), strictly speaking, is not a goat at all, but is more 
or less nearly related to the chamois, which it resembles in many of its habits and ways. It is a native of rugged and elevated mountains from central Idaho to British Columbia and Alaska. They are exceedingly rare in collections.

The Prong-horned Antelope (Antilocapra americana) is remarkable on account of the formation of its horns in a

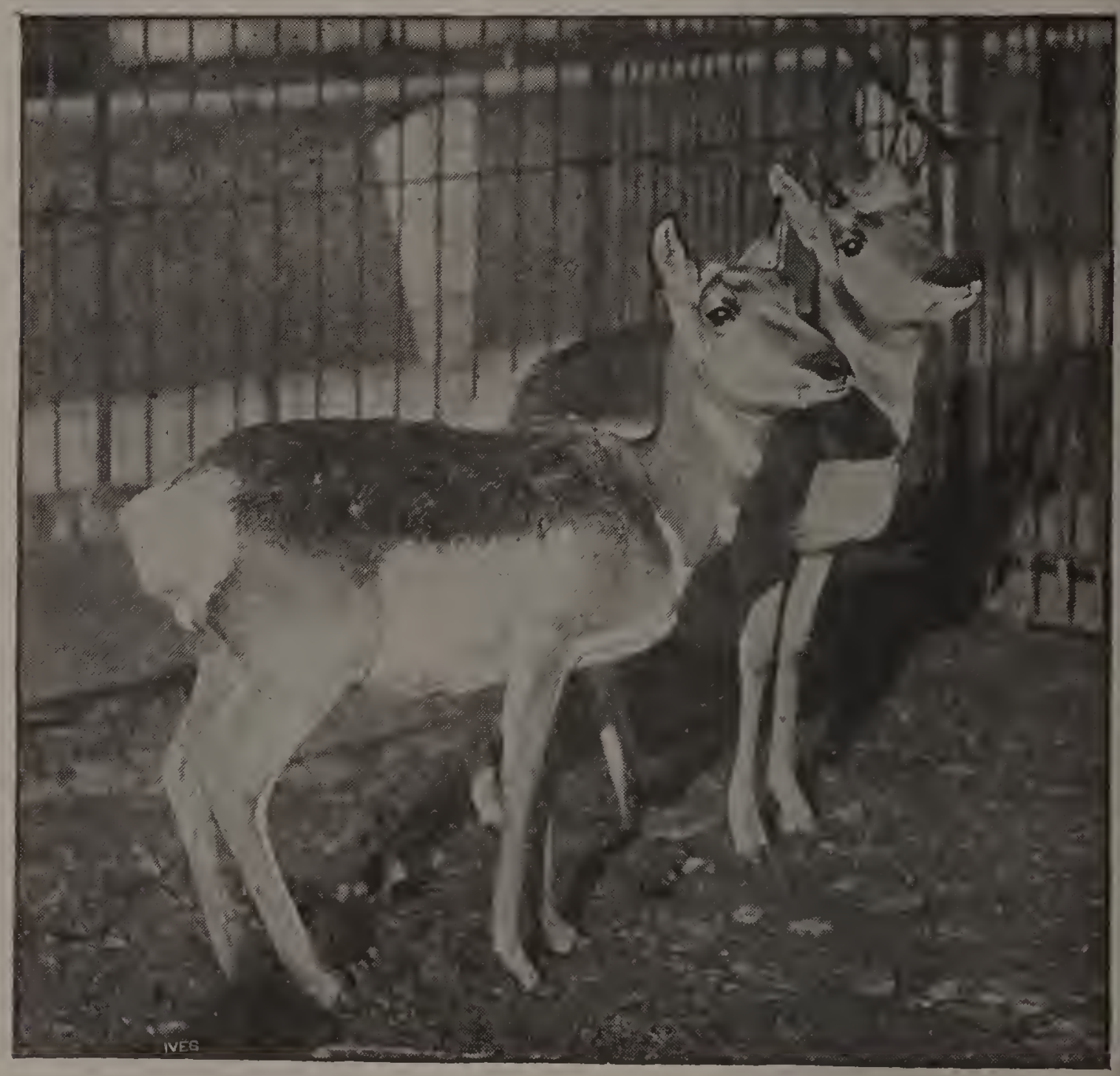

THE PRONG-HORNED ANTELOPE.

manner peculiar to itself alone. The horns of this species resemble in appearance those of the hollow-horned ruminants, in which the external covering of horny material grows around a solid, bony core. In this antelope, however, the outside horny part is shed and replaced, it is thought by some naturalists, annually, as in the deer; but with the important difference, that in the deer the antler is formed directly by a 
deposit from the blood, while in the antelope in question it is produced by growth and hardening of the epidermis or outer layer of the skin. The species is now confined to the plains of the temperate regions of the west, where they are becoming scarce. They are easily tamed, but are very delicate, and will not live for any length of time under restraint of any character.

The Red Deer or Stag (Cervus elaphus) of Europe is kept in one of these enclosures. This animal is closely similar to the wapiti, but is of smaller size and less imposing aspect.

Other deer resembling this species are found in northern and central Asia.

\section{No. 32.-THE CAMEL PEN.}

The Bactrian, or Double-humped Camel (Camelus bactrianus), and the Common Camel or Dromedary ( $C$. dromedarius) are both originally natives of Asia. The Bactrian camel comes from the high, cold plains of Tartary, where a few wild ones still remain, and is a more compact and powerful beast than the dromedary, which comes from the warmer climate of Arabia, and is lighter and more fleet of foot. They are much used in the sandy deserts of Arabia and northern Africa-nature having specially fitted their feet, like those of the ostrich, to the loose soil on which they walk, and also having provided them with a means of traveling for several days without requiring a fresh supply of water, part of the walls of the stomach supporting a double tissue, filled with cells, which absorb from the stomach, after drinking, a quantity of water sufficient to remain for some days as a reservoir, from which the necessities of the animal may be supplied. A number of camels were imported into Texas by the United States Government in 1857 , with the idea of making them available in military operations in the West; but owing to the stony nature of much of the soil, for which their feet are not adapted, the experiment was not altogether successful. A few years ago some of their descendants were said to exist in a wild state on the dry plains of Arizona, south of the Gila river.

Fossil remains of members of the Camelidae have been found in the United States, thus proving that they were once indigenous to this country. 


\section{No. 2I.-THE REPTILE HOUSE.}

THIs building was occupied by the collection of birds until the erection of the present Aviary, when the reptiles were moved into it. It proved, however, altogether inadequate to that purpose, and for some years the Society was obliged to neglect this important class of animals. In the summer of r 888 alterations and enlargement of the building were undertaken, the result being the present commodious and wellarranged structure.

The class Reptilia is composed of animals provided with lungs, a very simple digestive apparatus, and cold blood, a term which merely means that, unlike mammals and birds, so little heat is produced by the reptile itself that the temperature of its body depends chiefly upon that of the air or water which surrounds it. Many of them live in the water, but are compelled to rise to the surface for the purpose of respiration. With the exception of a few of the serpents and lizards, they are oviparous, and deposit their eggs on land. Reptiles proper are turtles, serpents, lizards, and saurians.

The members of the class Batrachia agree in many respects with the above. Their spawn, or eggs, is, however, generally hatched under water, and they are covered with a smooth skin in place of the scales with which reptiles are provided. The young-of which the tadpole of the frog is a familiar example-live entirely in the water, and breathe with gills. In some genera, as Siren and Necturus, these gills are retained through life, and project from the sides of the neck, where they may readily be observed, the blood which fills them giving them a rich crimson color. In others, as the frogs, toads, newts, and salamanders, a complete metamorphosis takes place, the gills of the immature animal disappearing altogether in the adult. In the genus Cryptobranchus the gills become reduced to a small orifice in the side of the neck, and the lungs are well developed.

Of the amphibians, the Siren (Siren lacertina), the AMphiuma (Amphiuma means), and the Proteus (Necturus maculatus) are usually in the collection. The two former are found in the soft mud of streams and ditches from Georgia southward. The specimens in the Garden rarely come 
out of the mud, except to get the worms on which they principally live. The menobranchus or proteus is from the fresh-water streams and lakes of the Middle States, and feeds upon worms, grubs, and larvæ.

The Hell Bender or Mud Devil (Cryptobranchus allegheniensis) is found in the river mud of all tributaries of the Mississippi, and occasionally in other localities in the Gulf States.

The salamanders and tritons, or newts, are found plentifully all over the United States. Many of them live entirely in the water, except at the breeding season. The REDBACKED Salamander (Plethodon cinereus erythronotus), the Two-Lined Salamander (Spelerpes bilineatus), the ReD Salamander ( $S$. muber), the Black Newt (Desmognathus nigra), and the SpotTed Newt (Diemyctylus viridescens) are among the most common species.

A very beautiful species, with bright yellow spots, is the Spotted Salainander of Europe ( $S$. maculosa). There are a number of other European species belonging to the genus Molge.

A number of curious amphibians (Amblystoma tigrina), from the elevated plateaus in the western United States, will be found in the vivarium. Their larval form, has large gill tufts and a crest along the spine and tail. These shrink up and disappear when the animal becomes mature.

The largest member of this group is the Giant Salamander (Cryptobranchus maximus) of Japan, which reaches sometimes a length of four feet. They are sluggish animals, feeding but seldom in captivity, and appear to be intolerant of light, becoming uneasy whenever the shade protecting them from the direct rays of the sun is removed.

The toads and frogs have a range co-extensive with the salamanders; the COMnon TOAD (Bufo lentiginosus) being found all over North America, with a number of well-marked varieties.

The best known of the frogs are the Bull Frog (Rana catesbiana), the Swamp Frog ( $R$. palustris), the Brook FroG ( $R$. clamitans), and the SPRING FROG ( $R$. virescens).

The North American fauna possesses a large and varied number of serpents (Ophidia), of which order over sixteen hundred species are found throughout the world. The only 


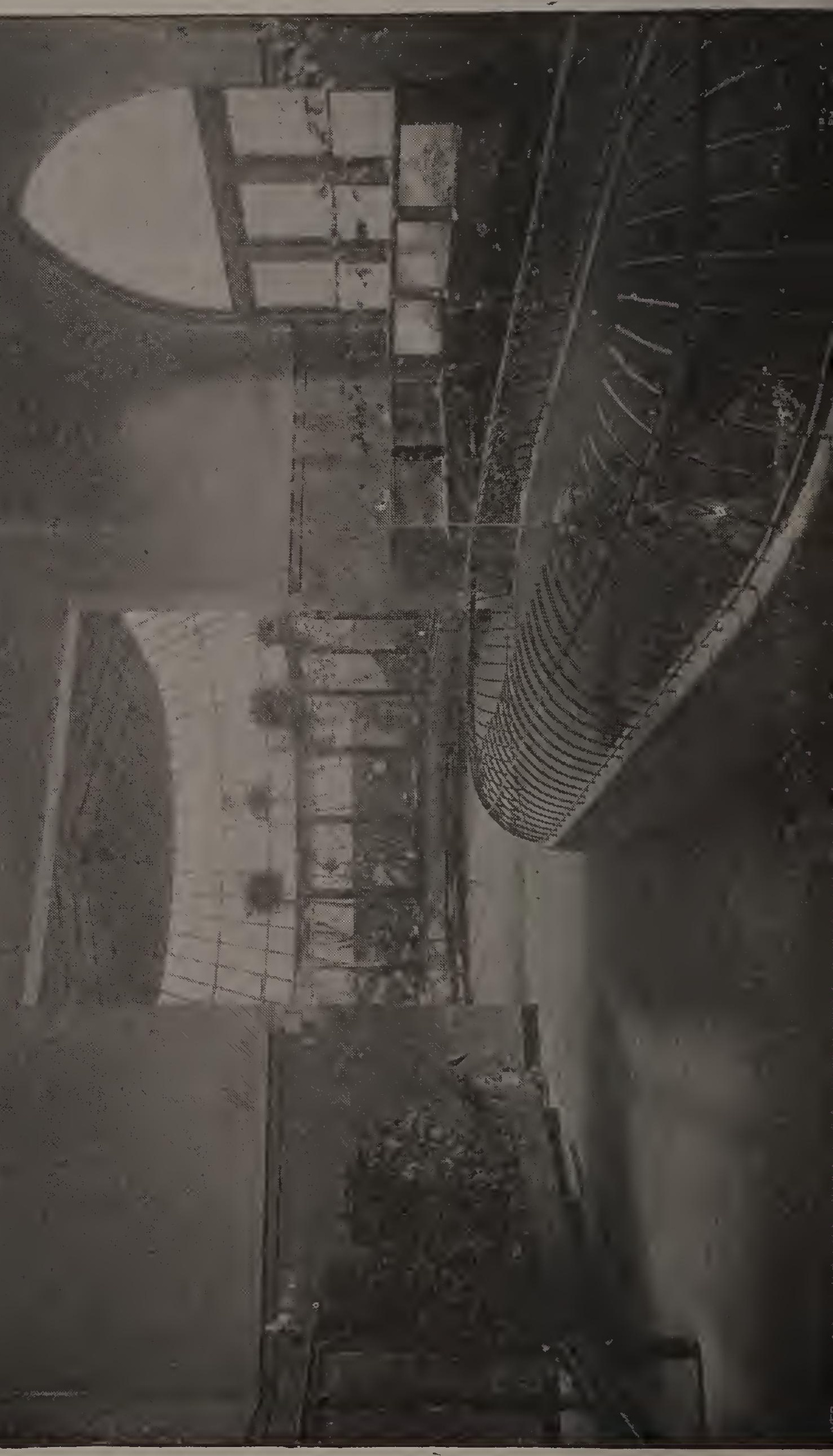


venomous snakes belonging to North America are the different varieties of the rattlesnake, the moccasin, the copperhead, and the coral snake. With the exception of the latter, these belong to the family Crotalide, distinguished by the presence of a deep pit on the side of the muzzle between the eye and the mouth, and by the possession of a pair of poison fangs in the upper jaw, which are erectable at will.

The rattlesnakes are common to the whole United States, even extending into Canada, and becoming more plentiful towards the south, where they grow to a large size, sometimes reaching as much as seven feet in length. They are characterized by a horny outgrowth of the epidermis at the end of the tail, known as the rattle, with which they make a whirring noise when excited, with the effect, it is presumed, of giving notice to their enemies that they are not to be trifled with without danger. The number of buttons, as the sections into which the rattle is divided are termed, has been commonly supposed to be a means of determining the age of the snake, but as they are frequently lost by accident, and are as frequently produced three or four at a time, it is evident that this belief, with a number of others of equally loose foundation which invest the popular mind regarding the serpent, may as well be abandoned.

It may be well here to dispose of two more of these delusions which meet with very general acceptance.

First.-The slender, forked organ, frequently and rapidly protruded from the mouth of snakes is not its "stinger," but is no more nor less than the tongue. No serpent has a sting or weapon of any kind other than its teeth.

Second. - There is no rational basis for the belief in a power of fascination consciously exerted by a snake upon its prey. The occurrences brought forward in support of the notion can be accounted for on purely psychological grounds.

There are some fifteen species of rattlesnake found within the limits of the United States, eleven of which are known only in the extreme south-west, the fauna of which is closely related to that of Mexico and Central America.

The Banded Rattlesnake (Crotalus horridus) and the Diamond Rattlesnake (C. adlamanteus) are the most wellmarked species of this genus; the former being most common in the Eastern and Middle States, while the latter ranges from North Carolina to Texas. 
The Western Diamond Rattlesnake ( $C$. atro $x$ ) and the Horned Rattlesnake ( $C$. cerastes) come from Texas, Arizona, and New Mexico. The South American species ( $C$. durissus) reaches a large size.

Say's Rattlesnake ( $C$. confluentus) is the most widespread species of the plains.

The Ground Rattlesnake (Sistrurus miliarius) and the Prairie Rattlesnake (S. catenatus) are small species from the south and west.

The Water Moccasin (Ancistrodon piscivorus) is confined to the wet and swampy lands throughout the south.

The Copperhead ( $A$. contortrix) is found almost all over the United States east of the Rocky mountains.

Many highly venomous crotaline snakes are found in tropical America, a number of which belong to the genus Lachesis, such as the dreaded FER DE LANCE (L. lanceolatus) of St. Lucia and Martinique and $L$. atrox from South America.

The vipers belong altogether to the old world; they much resemble the crotaline snakes, but externally lack the pit on the side of the muzzle, referred to above. Like rattlesnakes, they have the pre-maxillary bone, bearing the poison fang, hinged, as it were, so that the fang can be erected for use, at other times lying back against the roof of the mouth, like the blade of a closed knife. A typical member of this group is the Puff Adder (Vipera arietans) of South Africa. The Common Viper ( $V$. berus) and the Long-Nosed Viper ( $V$. ammodytes) are natives of Europe.

The cobras and the elapine snakes, known as proteroglyphs, while highly venomous, have fixed fangs, and are nearly related to the harmless colubrine snakes. Some of these last, having an opisthoglyph dentition, that is, having a long grooved tooth in the back of the upper jaw, are poisonous to small animals, though not dangerous to man.

The Coral Snake (Elaps fulvinis) of the Southern States is of a very mild disposition, and has hardly ever been known to bite, although in proportion to its size it is probably very highly venomous. It is one of the most beautiful of the order, being ringed with red, black, and 
yellow. The section to which it belongs has the centre of its distribution in the tropical zone, throughout the whole circle of the earth, and includes some of the most deadly forms; among others the Egyptian Cobra (Naia haje), the Indian Cobra ( $N$. tripudians), and the Snake-EATING Cobra ( N. bungara). This last is the largest venomous snake known, reaching a length of thirteen feet. It is native to the IndoMalayan region, as far east as the Philippines.

Some much-dreaded snakes are found in Australia, as the Purplish Death Adder (Pseudechis porphyriacus).

The following serpents, with a number of others which are usually in the collection, belong to the colubrine group. They are non-venomous and perfectly harmless to man, living on small birds, quadrupeds, reptiles, worms, and insects; several genera-Ophibolus and Abastor-eating small snakes of their own and other species.

The Rainbow Snake (Abastor erythrograimmus), Southern States.

The King Snake (Ophibolus getulus), Atlantic coast.

The Chain Snake (O. doliatus triangulus), Western States.

The Green Snake (Cyclophis vernalis), Eastern and Southern States.

The Pine Snake (Pityophis melanoleucus), south of New Jersey and Ohio.

The Bull Snake (P. sayi), south-western United States.

The Indigo Snake (Spilotes corais), Gulf States.

The Chicken Snake (Coluber quadrivittatus), Southern States.

The Mountain Black Snake (C. obsoletus), United States.

The Milk Snake (C. obsoletus confinis), Western States.

Fox's Black Snake (C. vulpinus), Western States.

The Corn Snake (C. guttatus), Southern States.

The Black SNake (Zamenis constrictor), United States.

The Whip Snake (Z. Alagellum, Southern States.

The Ribbon Snake (Eutcenia saurita), Eastern and Southern States.

The Garter Snake (E. sirtalis), North America. Sacken's Garter Snake (E. sackeni); Florida. 
The Cyclops Water Snake (Tropidonotus cyclopium), Florida.

The Flat-tailed Water Snake ( $T$. compressicaudus), Florida.

The Banded Water Snake ( $T$. fasciatus), Southern States.

The Common Water Snake ( $T$. sipedon), Eastern and Southern States.

The Hog-Nosed SNAKE or "SpREAding Adder" (Heterodon platyrhinos), United States east of Mississippi. "The lastnamed species is often called "Blowing Viper," and as it assumes a most threatening aspect when disturbed, it is commonly held in great dread. It is, however, one of the most harmless of snakes.

The boas are a group of serpents inhabiting the tropical zone, and attaining the largest size of any known members of the order, as the anaconda and boa of South America, and the python and rock snake of Africa and Asia. They are possessed of great power and kill their prey by compression; they swallow without difficulty animals which appear larger in circumference than themselves, the articulation of their jaws and ribs permitting of a great degree of distension. Dr. Hartwig, in "The Tropical World," treats in a most entertaining style of these serpents :-

"The kingly Jiboya (Boa constrictor) inhabits the dry and sandy localities in the Brazilian forests, where he generally conceals himself in crevices and hollows, in parts but little frequented by man, and sometimes attains a length of thirty feet. To catch his prey, he ascends the trees and lurks hidden in the foliage for the unfortunate agutis, pacas, and capybaras whom their unfortunate star may lead within his reach. When full grown he seizes the passing deer; but in spite of his large size he is but little feared by the natives, as a single blow of a cudgel suffices to destroy him. Prince Maximilian of Nen Wied tells us that the experienced hunter laughs when asked if the Jiboya attacks and devours man. The Sucuriaba, Anaconda, or Water Boa (Eunectes murinus), as it is variously named, attains still larger dimensions than the constrictor, as some have been found of a length of forty feet. It inhabits the large rivers, lakes, and marshy grounds of tropical America, and passes most of its time in the water, now reposing on a sand-bank with only its head above the surface of the stream, now rapidly sivimming like an eel, or abandoning itself to the current of the river. Such is its voracity that Firmin ('Histoire Naturelle de Surinam') found in the stomach of an Anaconda a large sloth, an iguana nearly four feet long, and a tolerably sized ant-bear, all three nearly in the same state as when they were first swallowed-a proof that their capture had taken place within a short time." 
Specimens will generally be found in the collection of the COMMON BOA (Boa constrictor) of South America, the EMPEROR BOA ( $B$. imperator), the TREE BOA (Epicrates angulifer) of Cuba, the COPPERY BOA ( $E$. cupreus) from Trinidad, and the ANACONDA (Eunectes murinus). The genus Epicrates belongs to a section of the family which are distinctively known as tree boas; they are rarely more than seven or eight feet long, are arboreal in habit, and are found in the West Indies and Guiana. Corallus hortulanus and $C$. ruschenbergeri are also tree boas, the latter species being very rare. Certain small-sized boas have developed a habit of burrowing, and live under ground. The Indian ERyx (Eryx johni), Conical Eryx ( $E$. conicus) of India, as well as BotTa's SNAKE (Charina botto) of California, are examples of these.

The pythons represent in the Old World the boas of America; among them are the Indian Python (Python molurus), the Two-Lined Python ( $P$. bivittatus), the Royal Python ( $P$. regius), and the West-African Python ( $P$. seb $e$ ). In spite of the enormous size reached by these serpents, their destructive powers are largely exaggerated, and it may be considered doubtful if any of them are dangerous to human life.

Comparatively small members of the Boida are the CARPET SNake (Python spilotes) of Australia and the MadagasCAR BOA (Boa madagascariensis).

The lizards are distributed throughout the world, being most common in the tropics and the warmer parts of the temperate zone. There are some nineteen hundred known species belonging to the order Lacertilia. Among the most common North American forms are :-

The Striped Lizard (Eumeces fasciatus), Middle Atlantic and Southern States.

The Six-Lined Lizard (Cnemidophorus sexlineatus), Southern States.

'The Brown Lizard (Sceloporus undulatus), Southern States.

The Horned Lizard (Phrynosoma cornuta), South-western United States and Mexico.

Douglass' Horned Lizard ( $P$. douglassi), Western States. Crowned Horned Lizard ( $P$. coronata), Western States. Short-nosed Horned Lizard ( $P$. platyrhina), Western States.

The Green Lizard (Anolis principalis), Southern States. 


\section{2}

These are all small and harmless, many of them living among trees and feeding upon worms, insects, \&c. They exist in great profusion in the dry regions of the southwest, bordering on Mexico.

The iguanas belong to this order. Some species attain a length of four and five feet; pass most of their time in trees and live on fruit and birds' eggs. They inhabit tropical America and the West Indies, where they are considered as very good eating by the natives.

A number of these have been exhibited in the collection, among them the NAKED-NECKED IGUANA ( $I$. delicatissima), the Common Iguana ( $I$. tuberculata), the Black Iguana (Metopoceros cormutus), and the rare Clouded IGUANa (Cyclura nubila).

Among other lizards in the collection are the BENGALESE and Egyptian Monitors (Varanus bengalensis and $V$. niloticus), the last sometimes reaching a length of seven feet; HaRdwick's Mastigure (Uromastix hardivicki), from India, the Dragon-Like Lizard (Dracana guianensis), from the forests of the Amazon, and the curious SLOw WORM (Anguis fragilis) of Europe.

The chameleons are found in the warmer portions of Europe, Asia, and Africa. In some species the head is ornamented by elevated crests and ridges; in all of them the power of changing color to accord with their surroundings is much developed.

An animal most repulsive in appearance is the Gila Monster (Heloderma suspectum), from Arizona. For a long time its reputed venomous qualities were in doubt, but recent research has fully demonstrated their existence, although the animal seems little inclined to use its power offensively. It and an allied species from Mexico are the only lizards known to be poisonous.

The Glass Snake (Ophisaurus ventralis) of the southern United States and the Dalmatian Glass Snake ( $O$. apus) from Europe are lizards resembling snakes in appearance, being destitute of legs.

The Tuatera of New Zealand (Sphenodon punctatus) is the only remaining member of an extinct order, Rhyncho- 
cephatia, of lizard-like reptiles, from which modern lizards and turtles are probably descended.

Of the Chelonia some two hundred species are known. These consist of the turtles proper, which are generally of large size and live in the sea; the terrapins, which live in streams, ponds, and marshes; and the tortoises or land turtles. There are a number of forms belonging to the American fauna, of which the following are on exhibition :-

The I_eatherback Turtle (Dermochelys coriacea), Atlantic coast.

The Green Turtle (Chelonia mydas), Atlantic coast.

The Soft-shelled Turtle (Triony $x$ ferox), Gulf States.

The Snapper Terrapin (Chelydra serpentina), North and South America.

The Musk Terrapin (Cinosternum odoratum), Eastern and Southern States.

The Mud Terrapin (Cinosternum pennsylvanicum), Eastern and Southern States.

Henry's Mud T'errapin ( $C$. henrici), Arizona and Mexico.

THE RED-BELlied TERRAPIN (Chrysemys rubriventris), Middle Atlantic States.

The Florida Terrapin (C. concinna), Southern States.

The Salt Water Terrapin, or Diamond-Back (Malacoclemmys terrapin), Atlantic and Gulf States.

The Checkered Terrapin (Chrysemys picta), Eastern and Southern States.

The Chicken Terrapin (C. reticulata), Gulf States.

Muhlenberg's Terrapin (Chelopus mulenbergi), Pennsylvania and New York.

Blanding's TORTOISE (Emys blandingi), western United States.

ThE Box TORTOISE (Terrapene carolina), Eastern and Southern States.

The Painted Box Tortoise ( $T$. omata), western United States.

The Western Gopher (Testudo berlandieri), southwestern United States.

Agassiz's Gopher Tortoise ( $T$. agassizi), Arizona and Lower California.

Gopher Tortoise ( $T$. polyphemus), Florida.

The Radiated Tortoise ( T. radiata), Madagascar. 


\section{4}

The Gopher Tortoise ( $T$. carolina), Southern States.

The Common Tortoise $(T$. graca), Europe.

The Great or Elephant-footed Tortoise (Testudo elephantopus) of the Galapagos Islands and the BRAzILIAN TORToIse (Testudo tabulata) are both South American forms.

Turtles inhabit the whole tropical and temperate zones.

The saurians comprise alligators, crocodiles, and their allies, and are found in tropical regions of the whole world. A number of the common alligators are kept here. The Rough-Eyed Caiman (Caiman sclerops) is from South America.

Alligators are easily distinguished from most crocodiles by their broad rounded muzzles, in the last this region being more or less constricted and pointed.

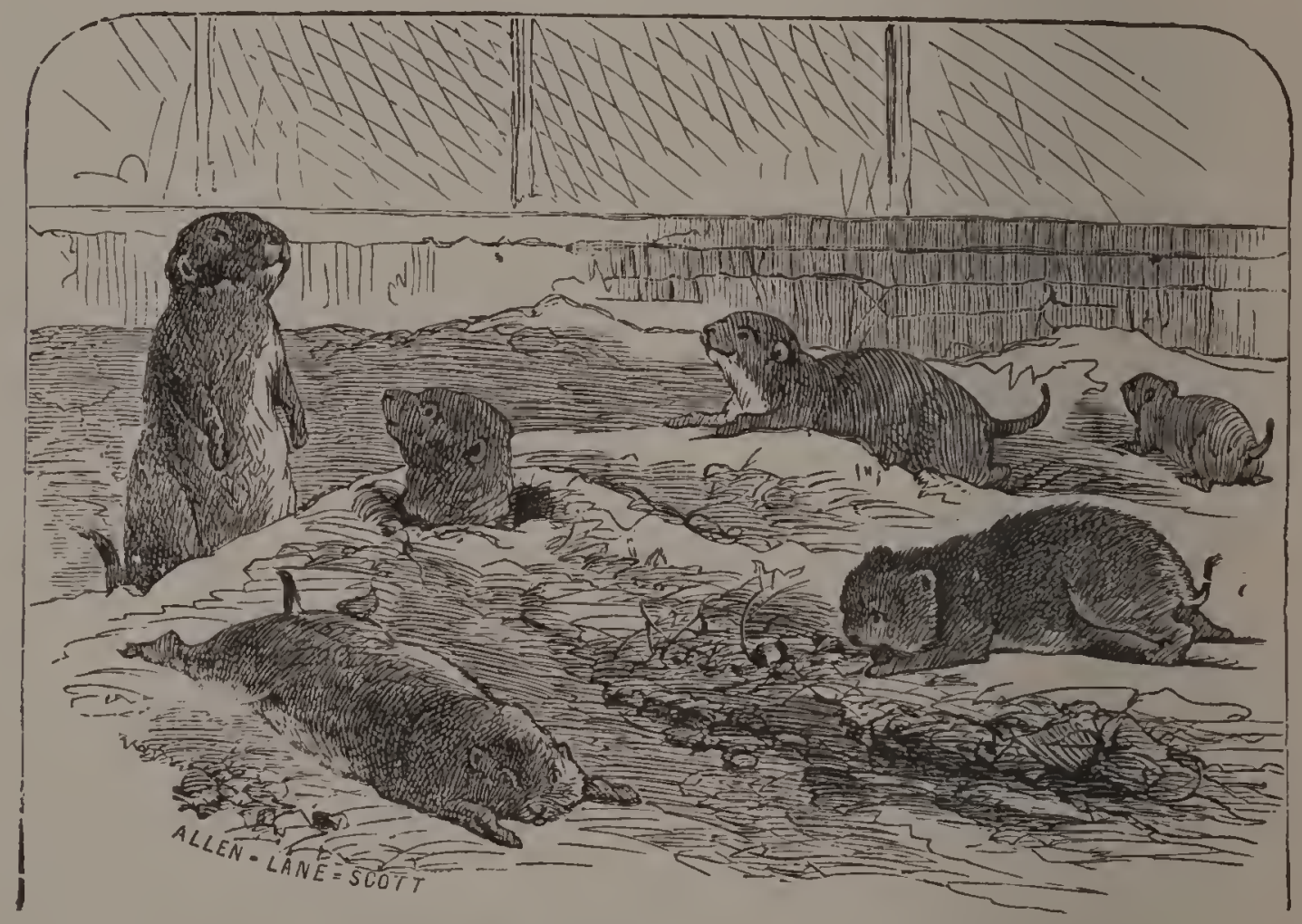

THE PRAIRIE-DOG VILLAGE.

\section{No. 22.-THE PRAIRIE-DOG VILLAGE.}

The Prairie Marmot (Cynomes ludovicianus), otherwise known as "prairie dog," is a small burrowing rodent, much resembling the spermophiles, which are common throughout the western part of the United States. 
They are found in immense numbers over the expanse of open country between the Missouri river and the Rocky mountains and south into Mexico-the villages formed by them sometimes occupying miles of country, which is completely honey-combed with their burrows; they dig to a considerable depth, those in the Garden having burrowed under a wall fourteen feet deep; they were overcrowded, however, and in a state of nature, with room to stretch out their villages on every side, it is not probable that they dig so deeply. The dogs are found in close association with the burrowing owl and the rattlesnake, which has given rise to the fable that they all live together on terms of intimacy and friendship. This is far from being the case, however, the evidence going to prove that the snake invades the home of the dog for the purpose of feeding upon the young, while the owlto save itself the trouble of digging its own habitation-takes possession of the deserted burrows which are left in the gradual change of location which is continually going on among the dogs. Strong evidence was given of a natural enmity existing between the two, by the introduction of a pair of the owls into the enclosure of the dogs at the Garden, -they were instantly attacked by the latter, and as their wings had been clipped, they were unable to get away, and although they fought desperately were finally killed.

Near by are a number of Woodchucks (Arctomys monax). This rodent, closely allied to the marmot of Europe, is well known to every farmer's boy from Canada to South Carolina; it burrows in the ground and when afforded proper facilities, as in this case, is rarely seen during the daytime. It is one of the most common of our wild animals, and may, perhaps, be better known under the name of ground hog-though why "hog" it is difficult to say, as it does not resemble that animal in any way whatever. The Siberian Mariot ( $A$. bobac) is of very similar habits.

The Common Skunk (Mephitis mephitica) is a small carnivore belonging to the large family Mustelida, comprising also the otters, weasels, badgers, \&c., all of which are carnivores of small or medium size, mainly living on land, though several of them, as the mink and otter, are essentially aquatic in habit. It inhabits the United States from the Missouri river eastward, - the western and south-western parts of the 


$$
96
$$

country being infested by several other species, one of which ranges into South America. The true skunks are confined to the New World; in them the anal glands characteristic of all the Mustelide reach their most complete development, and secrete a fluid which the animal can eject at will to a distance of several feet, and which possesses an odor at once the most powerful and intolerable of any known animal secretion. The fur of the skunk is very long and fine, and is much worn, under the euphonious designation of "Alaska Sable."

The American Badger (Taxidea americana) belongs to the same group as the skunk; it lives in burrows, which it excavates with its powerful claws, and is found through the western United States up to about latitude fifty-eight degrees, in British America, though it is seldom seen east of the Missouri river; southward it is replaced by a well-marked variety (berlandieri). The BADGER of Europe (Meles taxus) is an allied form.

\section{No. 20.-THE SQUIRREL CAGE.}

Among the true squirrels (Sciuride) of North America, those generally to be found in the collection are the SouthERN FOX SQUiRrel (Sciurus niger) of the Gulf States; the Northern Fox SquirRel (S. niger cinereus), from New Jersey to Virginia; the Gray Squirrel ( $S$. carolinensis), United States east of the Missouri river, and the RED SquirRel ( $S$. hudsonius), which ranges from British America to the Gulf States.

The gray squirrel is subject to much variation, the black as well as the white squirrel belonging to this species.

The Flying Squirrel (Pteromys volucella) is a pretty little rodent found throughout the United States, east of the Missouri river. Its aerial progression is merely a leap, prolonged by means of a fold of skin stretching between the fore and hind limbs on each side, which expands and bears the animal up for a short distance, after the manner of a kite.

A large number of squirrels inhabit Central and South America; they are mostly red and black in color, but vary so interminably that it is often hard to tell what species a given specimen belongs to. Some of them are usually to be seen in the Small Mammal House. Examples of these are 


\section{7}

the Peruvian Squirrel ( $S$. variabilis), the Red-bellied Squirrel ( $S$. amreogaster), and the Brazilian Squirrel ( $S$. astuans).

Several specimens of the pretty little European RED SQuiRREL (S. vulgaris) are also kept here.

Near by is a cage containing some STRIPEd Gophers (Spermophilus tridecimlineatus). The spermophiles form a large sub-group of the squirrel family; they live in burrows in the ground, but are directly connected with the tree squirrels by almost insensible gradations of form, one of which is the Iine-Tailed or Mexican Rock Squirrel (S. grammurus). It is difficult to distinguish this species, without close examination, from the true squirrels, which live in trees. The striped gopher is found from western Michigan to the Missouri river and south to Arkansas.

Richardson's Speriophile (S. richarilsoni), the Gray Gopher (S. franklini), and the Pouched Gopher (Geomys bursarius) are also North American forms.

The Chipmunks or Ground Seutrrels, of the genus Tamias, are another link in the chain of progression from gophers to squirrels; many species are found in North America and Asia. 


\section{INDEX.}

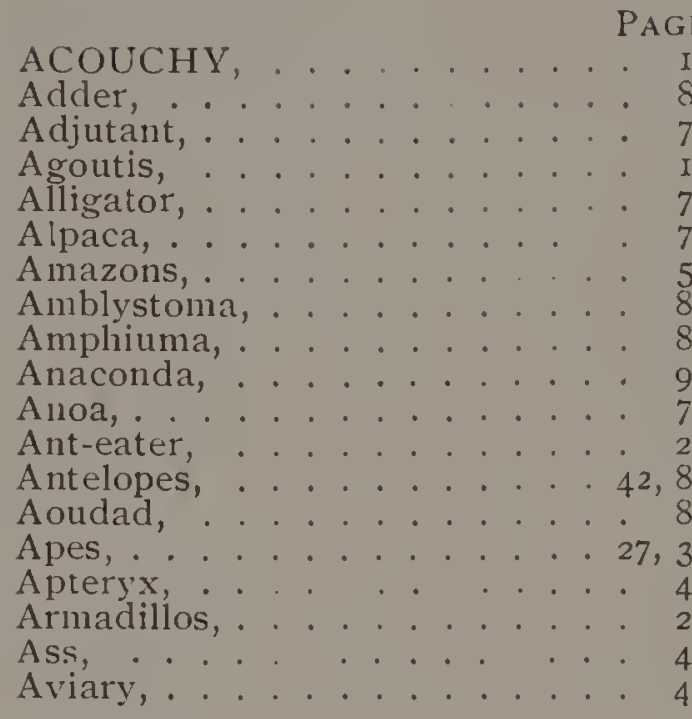

BABOONS, .......... 3I

Badgers, . . . . . . . . . . 96

Bandicoot, . . . . . . . 20 20

Bassaris, Ring-tailed, . . . . . . I7

Batrachia, ......... 84

Bats, . . . . . . . . 2I, 22

Bears, . . . . . . I4, 24,64

Beaver, . . . . . . . . . 23

Binturong, . . . . . . . . . 17

Bison, . . . . . . . . . 74

Bitterns, . . . . . . . . 72

Blackbird, ......... . 48

Boa Constrictor, . . . . . . . . . 9 I

Boar, Wild,.......... . 34

Bobac, . . . . . . . 95

Bobolink, . . . . . . . . 50

Buffaloes, . . . . . . . 42, 74,78

Buzzards, ......... 6 I

CAIMAN, . . . . . . . . 94

Camels,.......... 83

Capromys, . . . . . . . .

Capucins, . . . . . 32

Capybara, ......... . . 20

Caracal, . . . . . . . . . I4

Caribou, ......... . . 69

Carnivora House, . . . . . . . . 9

Cassowary, ......... . 46

Cats, . . . . . . . . . Io, I4

Cat Bird, . . . . . . . . 48

Cattle Pens, . . . . . . . . 78

Cavy, . . . . . . . . . I9

Cayote........... . 78

Chameleon, . . . . . . . . 92

Chamois, . . . . . . . . . 8I

Cheetah, ......... I2

Chevrotains, . . . . . . . . 43

Chimpanzee, . . . . . . . . . . 27

Chipmunks, .......... . 97
PAGE

Civet, ............ I7

Clouded Leopard, $\quad . \quad$ is

Coati, . . . . . . . . . . . $\begin{aligned} & \text { I } 8 \\ & \text { Cobra, }\end{aligned}$

Cockatoos, . . . . . . . . 54

Condor, . . . . . . . . . 63

Collures, . . . . . . . . . . 53

Coot,.......... . . 60

Cormorant, . . . . . . . . . . 59

Couguar, . . . . . . . . . . I 3

Coypu, . . . . . . . . . . . 20

Cranes, . . . . . . . 60, 7 I

Crocodile, . . . . . . . . . . 73

Crows, . . . . . . . . . . . 50

Cuckoo, . . . . . . . . . . 5 I

Curassows, . . . . . . . . . 56

Curlew,........... . . 60

DARTER, . . . . . . . . 59

Deer House, . . . . . . . . . . . . . . . 4 . 4

Deer Park, . . . . . . . . . 69

Deer, ....... $43,70,83$

Dingo, . . . . . . . . . 77

Douroucouli, . . . . . . . . . 33

Doves, . . . . . . . . . . 55

Dromedary, . . . . . . . 83

Ducks, . . . . . . . . . 65

EAGLES, . . . . . . . 6 6

Echidna, ................. . . 45

Egret, . . . . . . . . . . . 72

Eland, . . . . . . . . 42

Elephants, . . . . . . . . . . 35

Elephant House, . . . . . . . . . . . 34

Elephant Pond, . . . . . . . . . . 34

Elk, . . . . . . . . . . . $\begin{aligned} & 34 \\ & \text { I } 5\end{aligned}$

Emu, . . . . . . . . . . 47

Eryx, . . . . . . . . . $9 \mathrm{~g}$

Eyra,........... ${ }^{4} 4$

FALCONS, . . . . . . . . 62

Fer de Lance, .

Flamingo, .. . . . . . . . . 73

Foxes, . . . . . . . . 76

Frogs, . . . . . . . . . 85

GALAGO, .......... 33

Gallinule, . . . . . . . . . . . 63

Gamnets, . . . . . . . . . 58

Gazelles, . . . . . . . . . . . 43

Genet, . . . . . . . . . . . . 17

Gibbon, . . . . . . . . . . . . 29

Gila Monster, . . . . . . . . . . . . . 92

Giraffe, . . . . . . . . . . 37

Glass Snake, . . . . . . . . . . . . . .

Gnus, . . . . . . . . . . . . 42

Goats, . . . . . . . . . . . 80

Goose, . . . . . . . . . . . 65

Gophers, . . . . . . . . . . . . . 97

$(98)$ 


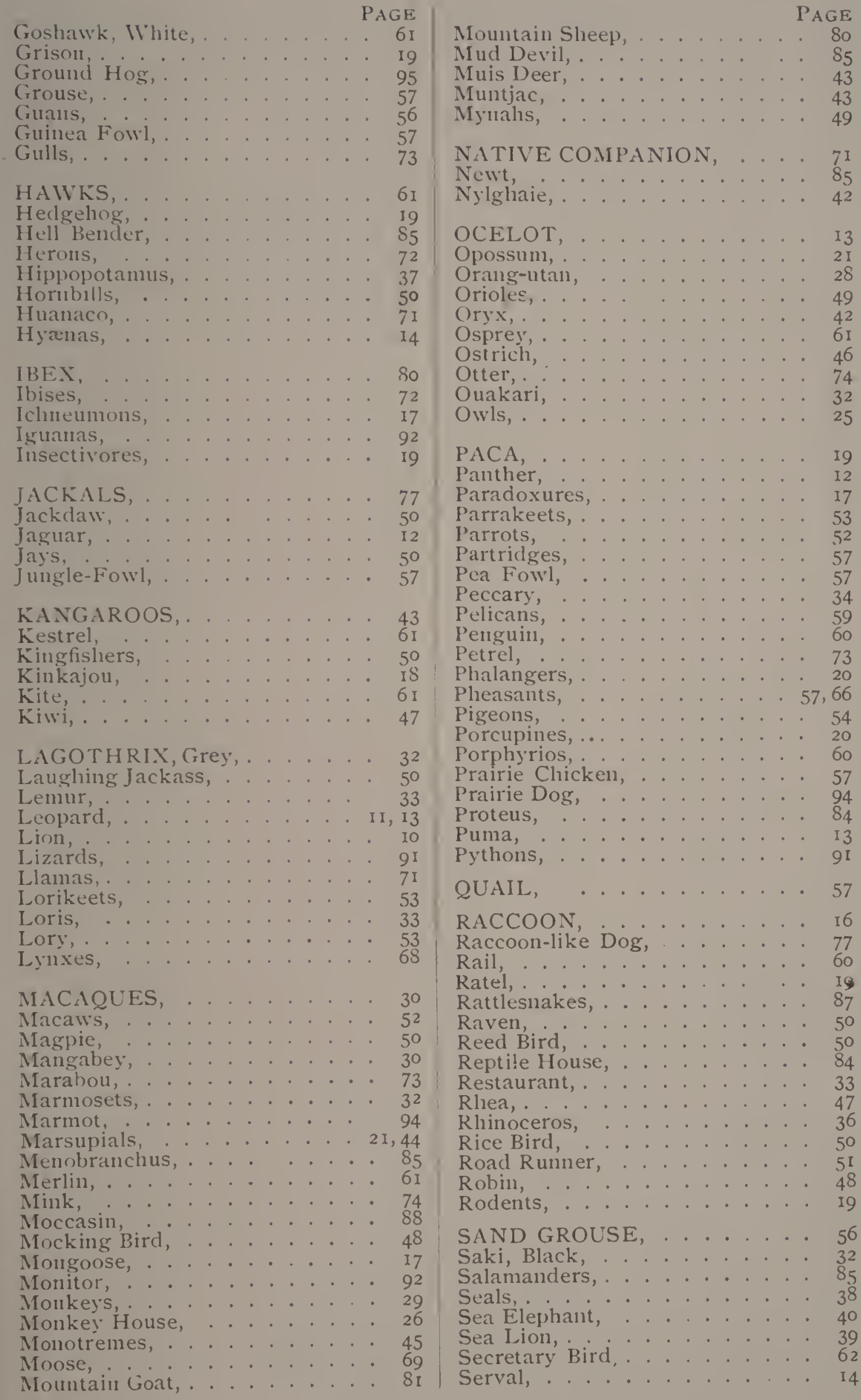




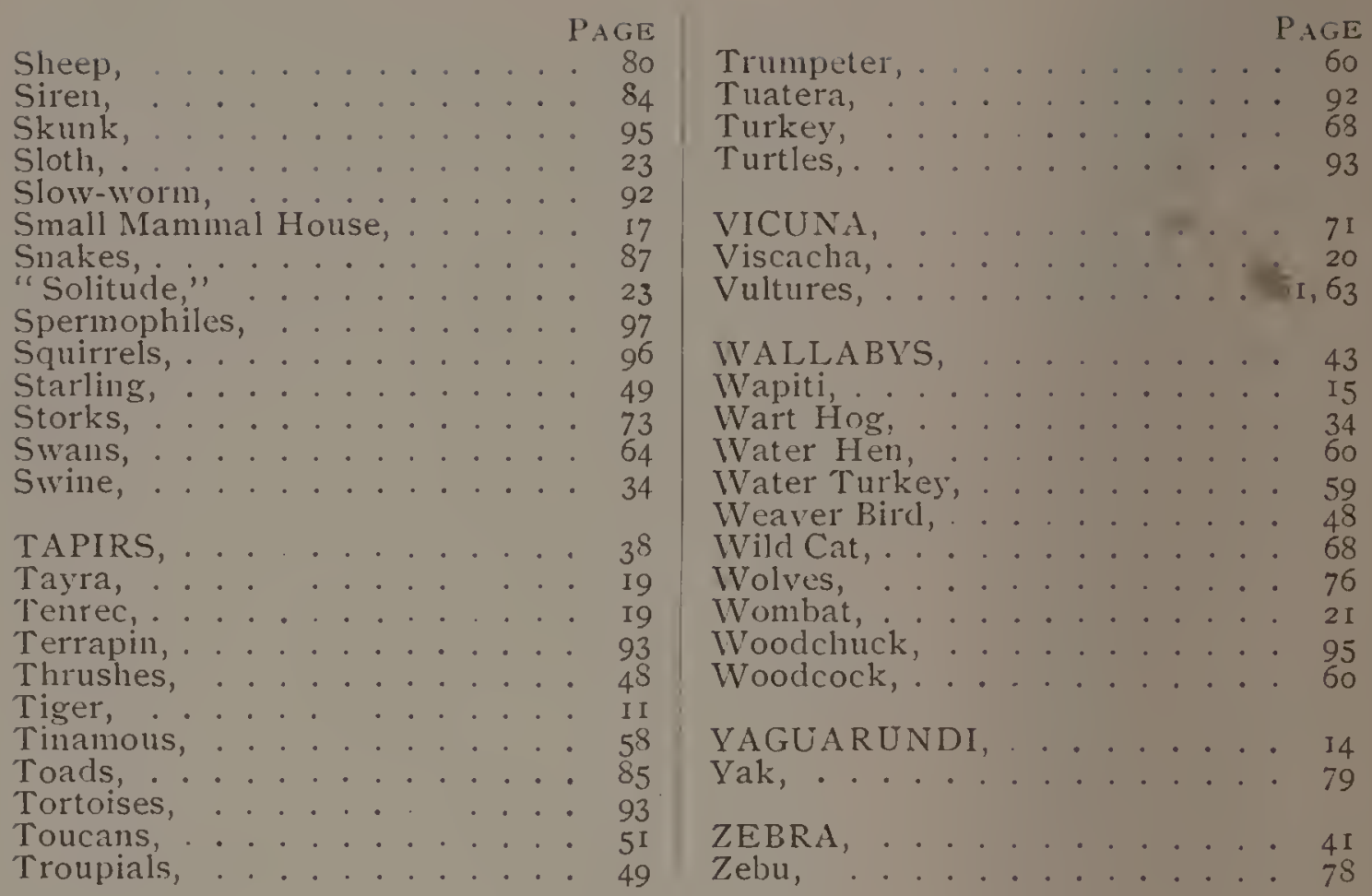


MEANS AND WAYS OF CONVEYANCE TO AND FROM THE GARDEN OR NEAREST POINTS.

\section{CITY PASSENGER RAILWAYS.}

Girard Avenue, leading direct to the northern gate.

Arch Street, via Spring Garden Bridge, to Thirty-fourth Street, thence a short walk direct to the southern gate.

Vine Street, same route.

Lombard and South Streets, to the same point.

\section{PHILADELPHIA \& READING RAILROAD}

Has a station at Girard Avenue, within five minutes' reach of the Garden. 
LIBRARY OF CONGRESS

\section{THE GARDEN}

Is open to visitors every day from 9 A. M. until half an hour before sunset; those who are in the Garden at that time will be permitted to remain until the bell rings at sunset.

\section{PRICES OF ADMISSION.}

Adults

25 cents.

Children under I2 years

Package of 5 Adult's tickets

IO 6

Package of I2 Children's tickets

\$I 00

I 00

On Saturday and all public holidays (except $4^{\text {th }}$ of July) the rate of admission is: Adults, Io cents; Children, 5 cents.

Special rates to large Excursions on application to the Superintendent. 